Historic, archived document

Do not assume content reflects current scientific knowledge, policies, or practices. 



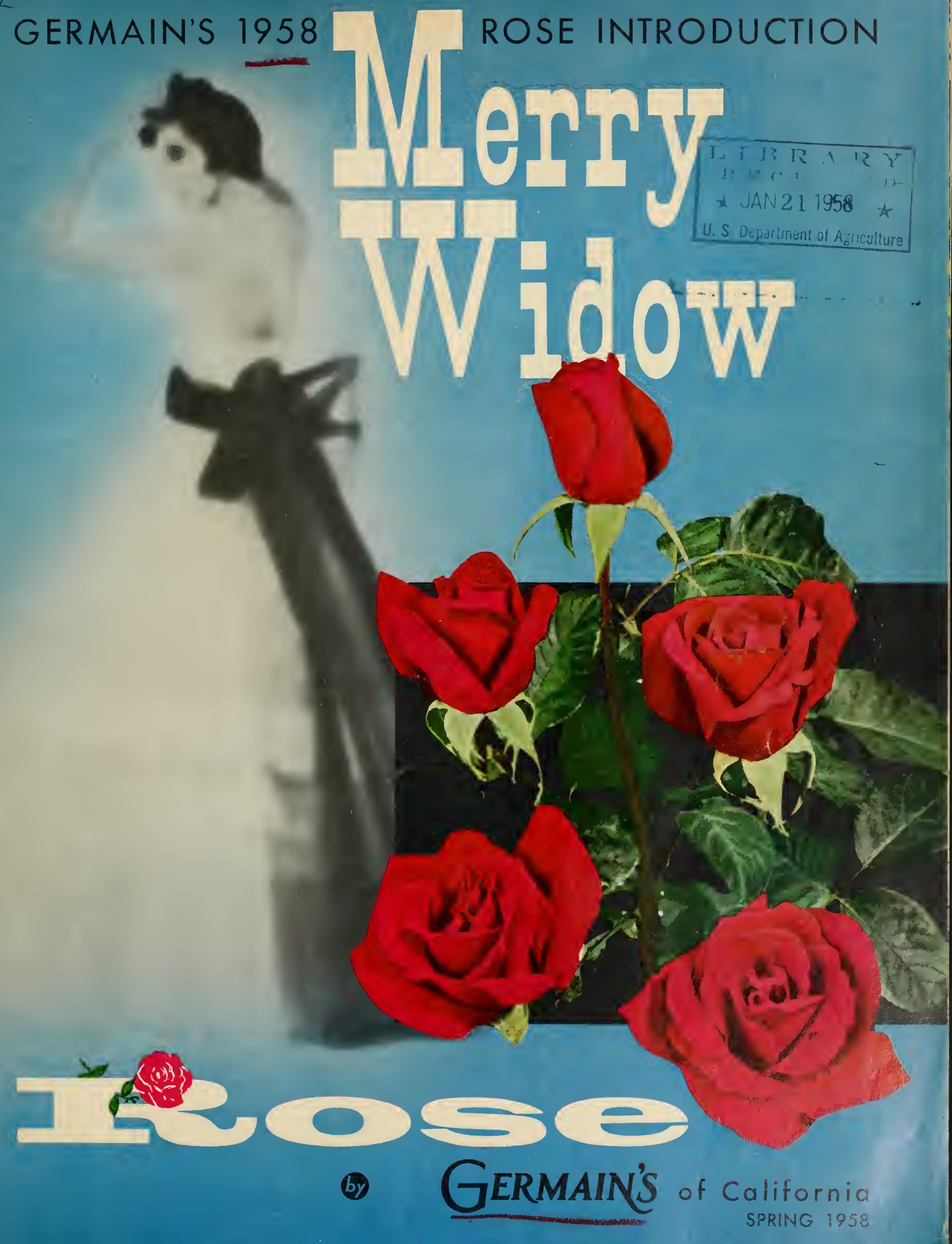




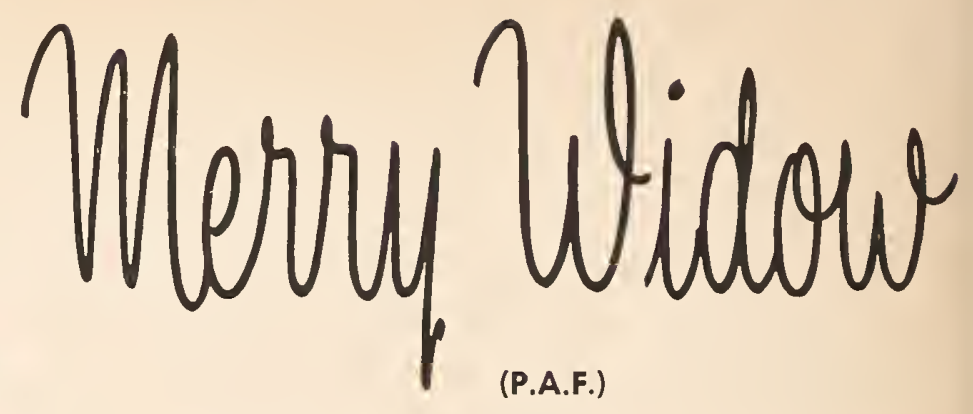

THIS SPECTACULAR NEW GRANDIFLORA IS AS GAY AND ALLURING AS ITS NAME

A New Red Rose ... exciting and radiantly beautiful, with vibrant, deep crimson, nonfade blooms. Exquisitely formed high-centered buds open to deep crimson, semidouble flowers with velvety textured petals. The profusion of blooms are borne both singly and in clusters on unusually long cutting stems ... 12 to 18 inches. Merry Widow will produce armloads of cutting flowers to grace your home-bring your garden indoors.

The Merry Widow has a particularly pleasing fragrance, reminiscent of the old-fashioned red rose. This newest Germain's grandiflora rose, another Dr. Lammerts original, attains a height of 4 to $41 / 2$ feet. The entire bush is gloriously clothed in dark green "leathery foliage. Grown with expert care this gorgeous GRANDIFLORA combines the abundant bloom of the FLORIBUNDA with the magnificent flowers and stems of the HYBRID TEA.

NS8232

$\$ 2.75$ Each

3 for $\$ 7.20$

\section{Las Vegas (Pot. 1486)}

AMERICA'S MOST FABULOUS HYBRID TEA ROSE SYMBOLIZING AMERICA'S MOST FABULOUS CITY

ALL THE WARMTH AND GLOW OF A DESERT SUNRISE FOR THE FIRST TIME CAPTURED IN A ROSE

The Las Vegas, Germain's 1957 rose introduction, is a radiant, warm, salmon-pink with a golden sheen at the base of each petal. The large, long, pointed buds open into highcentered blooms revealing the warm glowing color of the rose. As the blooms further develop, the petals cup and the spectacular color becomes more intense, giving an even deeper radiance to the flower. The blooms, measuring up to 6 inches across, are produced freely on exceptionally long cutting stems. Las Vegas is a truly long lasting cut flower, whose petals have a satiny lustre that imparts a depth and warmth to the bloom, such as that seen in a desert sunrise.

The plants bearing these gorgeous flowers are vigorous and well branched. The foliage covers the plant well, with semiglossy dark green leaves.

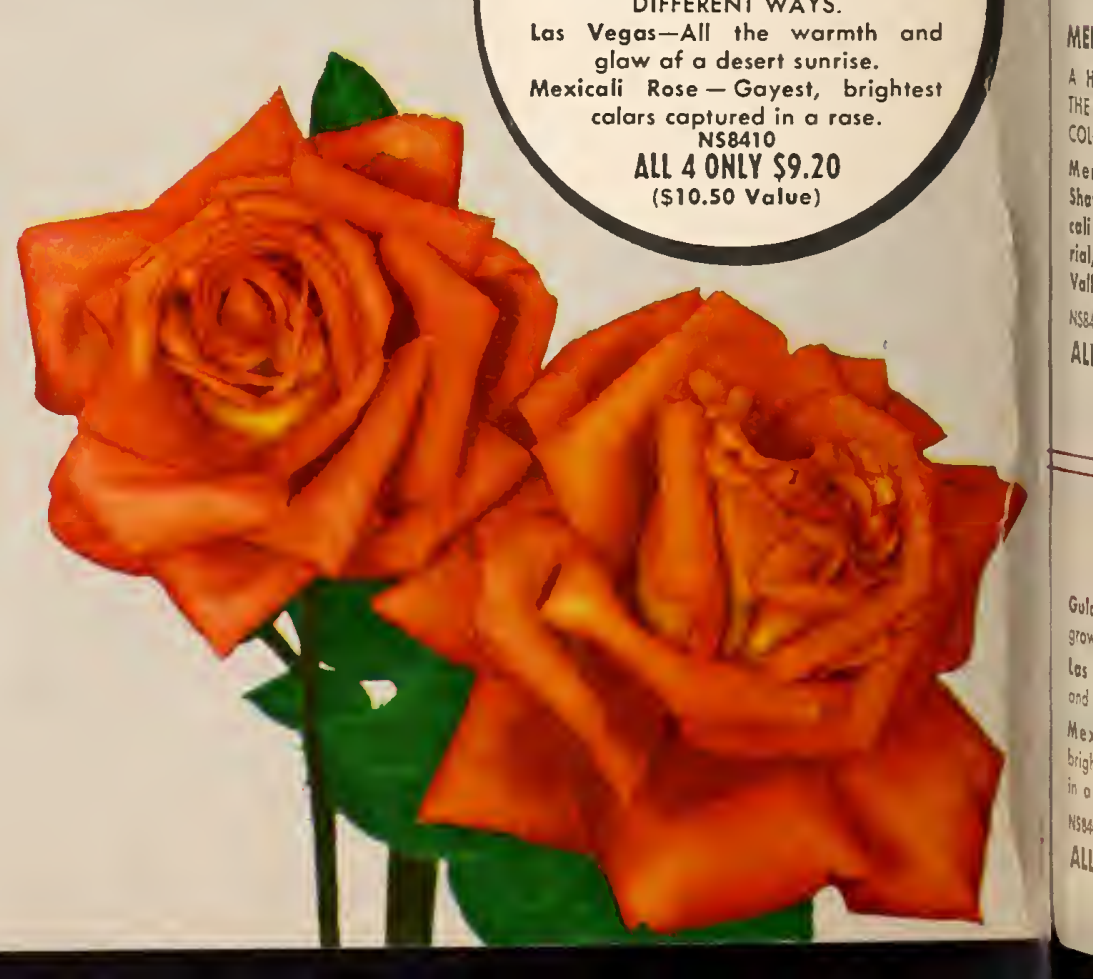


1957 A.A.R.S. Winner-First Pillar \& Climbing Rose in 16 Years to Win the National All America Award. No Other Rose Has All These Spectacular Features.

Leading rosarians agree: "No other rose like this in floricultural bistory."

GOLDEN SHOWERS is the first winter-hardy, ever-blooming Pillar and Climbing rose that blooms continuously from early spring until late fall.

GOLDEN SHOWERS lends itself to any landscape treatment; as a beautifully arching, self-supporting Pillar Rose, 8 to 10 feet tall; trained as a climber, this 1957 A.A.R.S. winner will reach up and along a trellis or a fence. Or it can be shaped as an eye-level symmetrical bush, combining exquisitely shaped daffodil yellow, long pointed buds with fragrant, high centered, 25 to 30 petaled, $41 / 2$ to 5 inch yellow open blooms. Almost thornless, with long beautifully decorative bronze cutting stems, Golden Showers lends itself to spectacular cut flower arrangements. The plant is magnificently covered clear to the ground with large, glossy foliage, and is so vigorous that it is highly resistant to rose diseases such as mildew and black spot.

NS8266

$\$ 2.75$ Each

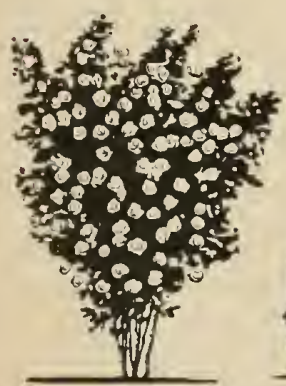
SELF-SUPPORTING
PILLAR ROSE

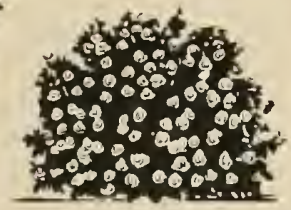

EYE-LEVEL
ROSE BUSH
3 for $\$ 7.20$

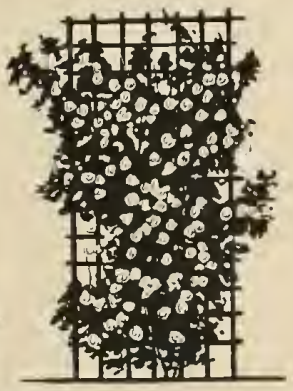

WINTER HARDY EVER-
BLOOMING CLIMBER

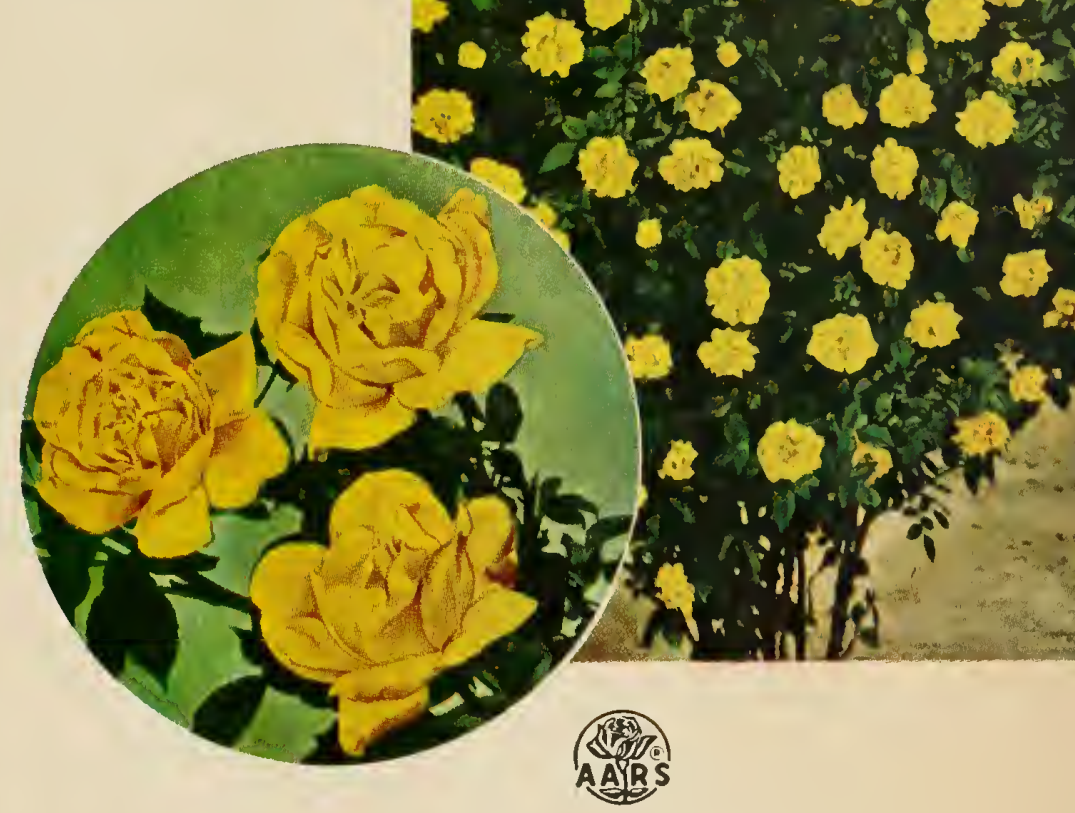

NEW! A 3-WAY FUNCTIONAL ROSE

THE ONLY VARIETY THAT CAN BE GROWN 3 DIFFERENT WAYS! THE ROSE THAT STARTED AN ENTIRELY NEW TREND IN ALL-ROSE LANDSCAPE DESIGN FOR THE MODERN HOME.

\section{GERMAIN'S \\ MELODY COLLECTION}

A HARMONIOUS BLEND OF THE MOST BEAUTIFUL ROSE COLORS

Merry Widow, Golden Showers, Las Vegas, Mexicali Rose, Chrysler Imperial, Queen Elizabeth, Sun Valley

NS8405

ALL 7 ONLY $\$ 15.60$ (\$18.00 Value)

\section{TRIPLE TREAT COLLECTION}

Gulden Showers - Can be grawn 3 DIFFERENT WAYS. Las Vegas-All the warmth and glaw af a desert sunrise. Mexicali Rose-Gayest, brightest calors ever captured in a rose.

N\$8400

ALL 3 ONLY $\$ 6.75$ (\$7.75 Value)

\section{Mexicali Rose (Pat 1486)}

This truly spectacular floribunda, acclaimed one of the most unusual developed in this century, introduces gay, vivid colors-bright as a Fiesta-to achieve one of the most dazzling displays ever created in the rose world!

Imagine these exquisitely shaped buds of bright yellow, suffused with vivid red, opening to lovely 4-inch blooms of deep yellow-then turning various bright shades of deep rose pink-maturing to a brilliant cerise red. As the blooms open, the petals begin to quill into a spectacular dahlia form. These excitingly vivid and fragrant flowers are borne in great profusion-both in clusters and singly - and bloom again and again all season long. The MEXICALI ROSE bush grows 4 to 5 feet tall, is clothed with bronzy foliage and is extremely disease resistant. It provides strong stems for cut flowers, and also makes an excellent hedge.

NS8233

3 for $\$ 6.60$
MEXICALI ROSE-GAYEST BRIGHTEST ROSE EVER DEVELOPED 


\section{Three Great?}

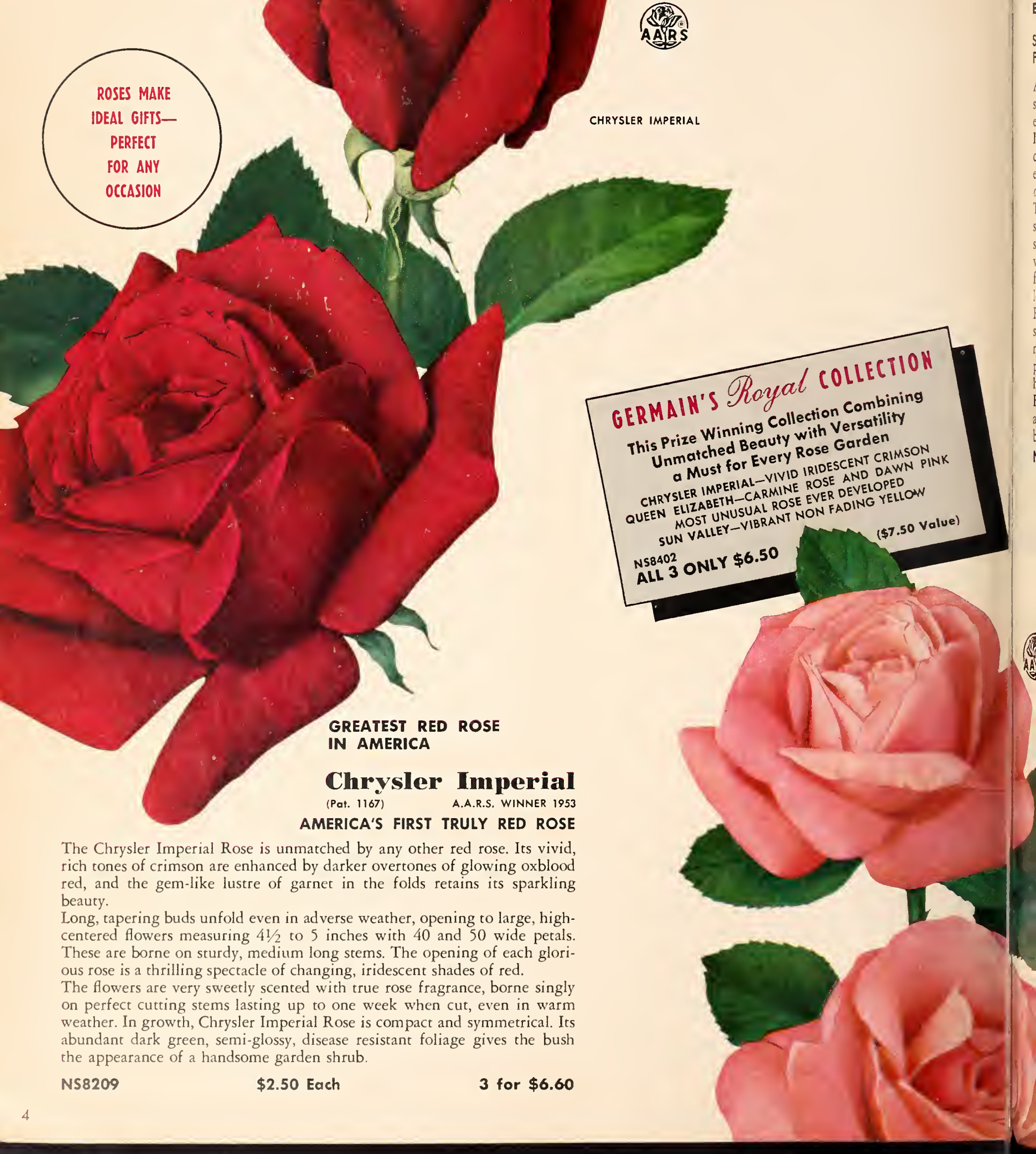




\title{
Proize Winners
}

\author{
Sum Valley (Pat. 1135)
}

\section{WARMEST, RICHEST, MOST RADIANT YELLOW EVER CAPTURED IN A ROSE}

\section{SYMBOLIZING THE BREATH TAKING BEAUTY OF FAMED SUN VALLEY}

At last-in "SUN VALLEY"-Germain's presents the warmest, richest, most vibrant yellow ever captured in a rose.

Its true guinea golden yellow holds its magnificent brilliant tone in open blooms for dayseven in bright hot sunshine-without a trace of fading!

The full, beautifully shaped buds open to large, strong and lasting blooms on long straight stems. The foliage is disease resistant and its vigorous, shining dark green tone forms a perfect foil for the golden flowers borne in seasonlong profusion.

Rose growers, from coast to coast, in conclusive trials, have found "Sun Valley" the purest, non-fading yellow rose-and one that holds its pure color better-than any yellow rose they have seen.

For masses of dazzling sunshine in your garden all season-and long-lasting brilliant yellow bouquets-"Sun Valley" should be a "must."

N58253 \$2.50 Each 3 for $\$ 6.60$

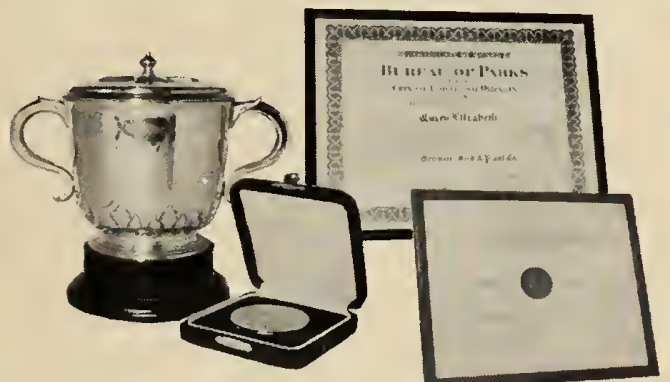

QUEEN ELIZABETH
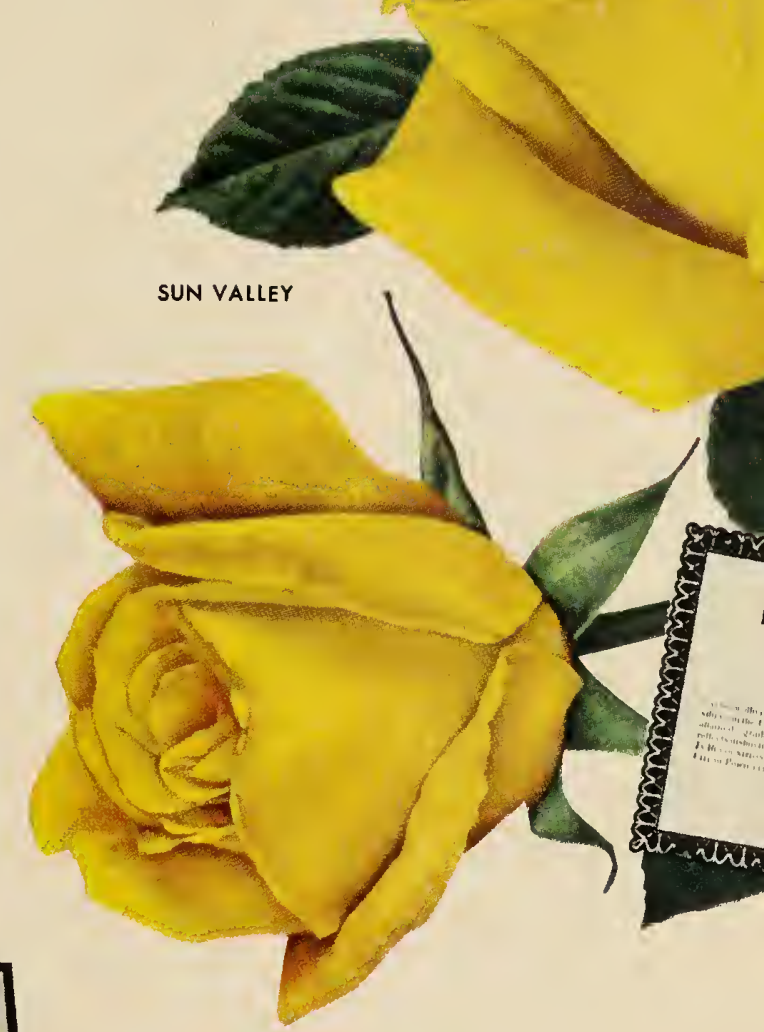

THE QUEEN WON THEM ALL

Gertrude M. Hubbard Gold Medal

National Rose Society of England-Gold Medal

and President's Trophy

Bureau of Parks-City of Portland

Japan Rose Society's Gold Medal

\section{Queen Elizabeth (Pat. 1259) 1955 All America Winner \\ THE ROSE THAT CREATED A NEW CLASS WORLD'S ONLY A.A.R.S. GRANDIFLORA WINNER}

A new breathtaking color in roses-combining Soft Carmine Rose and Dawn Pink. IMAGINE! BOTH ON ONE BUSH! Flowers borne regally single on long straight stems, and gorgeous clusters of blooms as well! Even the bloom clusters have stems long enough so that the flowers can be used individually in vases, flower arrangements, etc.

Queen Elizabeth is the most unusual and wonderful rose ever offered. First winner in the GRANDIFLORA Class of roses, you'll enjoy the profusion of season-long bloom of the FLORIBUNDA, as well as the wonderful bud forms, large, long-lasting flowers and splendid cutting stems of the HYBRID TEA.

COLOR? You'll really be thrilled when you see the superb and radiant PURE PINK shade, hitherto found only in choicest CATTLEYA ORCHIDS, and never before captured in a rose.

THE BUSH? The entire bush is gloriously clothed right to the ground with glossy, deep green foliage. 


\section{President Eisenhower (Pat. 1217)}

Rich and exciting, large, brilliant red blooms on long strong stems. Blooms continuously and is very fragrant.

Plant grows $2 \frac{1}{2}$ to 3 feet tall, is heavily caned and bushy. Dark green, leathery, disease-resistant foliage adds to its virtues.

NS8242

\$2.25 Each

3 for $\$ 6.00$

\section{Helem Traubel (Pat. 1028)}

\section{ALL-AMERICA WINNER FOR 1952}

Named for the great American singer, it is a blend of warm pink and luminous apricot with a bright undertone of near orange. Magnificent buds, long and graceful. Often 6 inches across, the open flowers maintain rich color, and have a fine spicy fragrance. A tall attractive bush that is seldom without buds or blooms.

\section{Candleglow (Par. 1199)}

Handsome pointed buds of a glowing buff and warm pink shade. The flowers are deeper in color in cooler weather, with a tint of golden yellow at the base of each petal. An exceedingly good keeper as a cut flower. It has a soft old rose fragrance. The dark green foliage sets off the color of the flower extremely well. Flowers are often five to six inches across when fully open.
N58204
$\$ 1.75$ Each
3 for $\$ 4.65$

\section{Rose Marie Reid (Pat. 1487)}

Rose Marie Reid is an exceptionally tall, vigorous growing $\mathrm{Hy}$ brid Tea which bears large quantities of very double flowers. The beautifully shaped buds-long and full-open to a soft dawn-pink. These long-lasting flowers measure 5 to 6 inches across, and have 45 to 50 petals. Its exquisite blooms are set off majestically by deep green, leathery foliage. The blooms make gorgeous cut flowers because of extra long stems. $\$ 10.54$ 
1955 A.A.R.S. WINNER (Pat. 1304) Tifiamy

The outstanding Hybrid Tea Rose for 1955. Extremely LARGE blooms and vigorous growth. Long pointed buds, golden yellow at the base, shading to gorgeous phlox pink. Each flower opens to a perfectly formed double high-centered bloom. Long stems and outstanding fragrance plus beautiful dark foliage provide a real winner for your garden.

NS8256

$\$ 2.50$ Each

3 for $\$ 6.60$

(Pat. 652) Best Regarods

This magnificent rose presents a strikingly beautiful color combination. On the inside, a brilliant cardinal red suffuses the upper part of its lovely petals which are marked at the base with a contrasting deep yellow tone. The outside of the flower is vivid Tyrian rose, heavily tinged with a glittering coppery oversheen. NS7201

$\$ 1.50$ Each

3 for $\$ 3.90$

1958 A.A.R.S. WINNER (Pat. 1359) White Knight THE FIRST WHITE HYBRID TEA EVER AWARDED THE A.A.R.S. HONOR. Medium long, pointed buds open to high-centered blooms 4 to 5 inches in diameter. Petals of the purest white are retained without spot or blemish. White Knight is a vigorous, disease-resistant plant of medium height, and the long, strong stems make it ideal for cut flowers.

NS8260

$\$ 3.00$ Each

3 for $\$ 7.95$

1954 A.A.R.S. WINNER (Pat. 1176) MOjave

Exciting Hybrid Tea rose with thrilling radiant orange colored flowers. When your MOJAVE blooms this season you can see why this variety has been selected as an A.A.R.S. winner. Produces large tapering buds which are pleasantly fragrant. Tall upright growth and luxurious foliage make this variety outstanding. NS8236

$\$ 2.75$ Each

3 for $\$ 7.20$

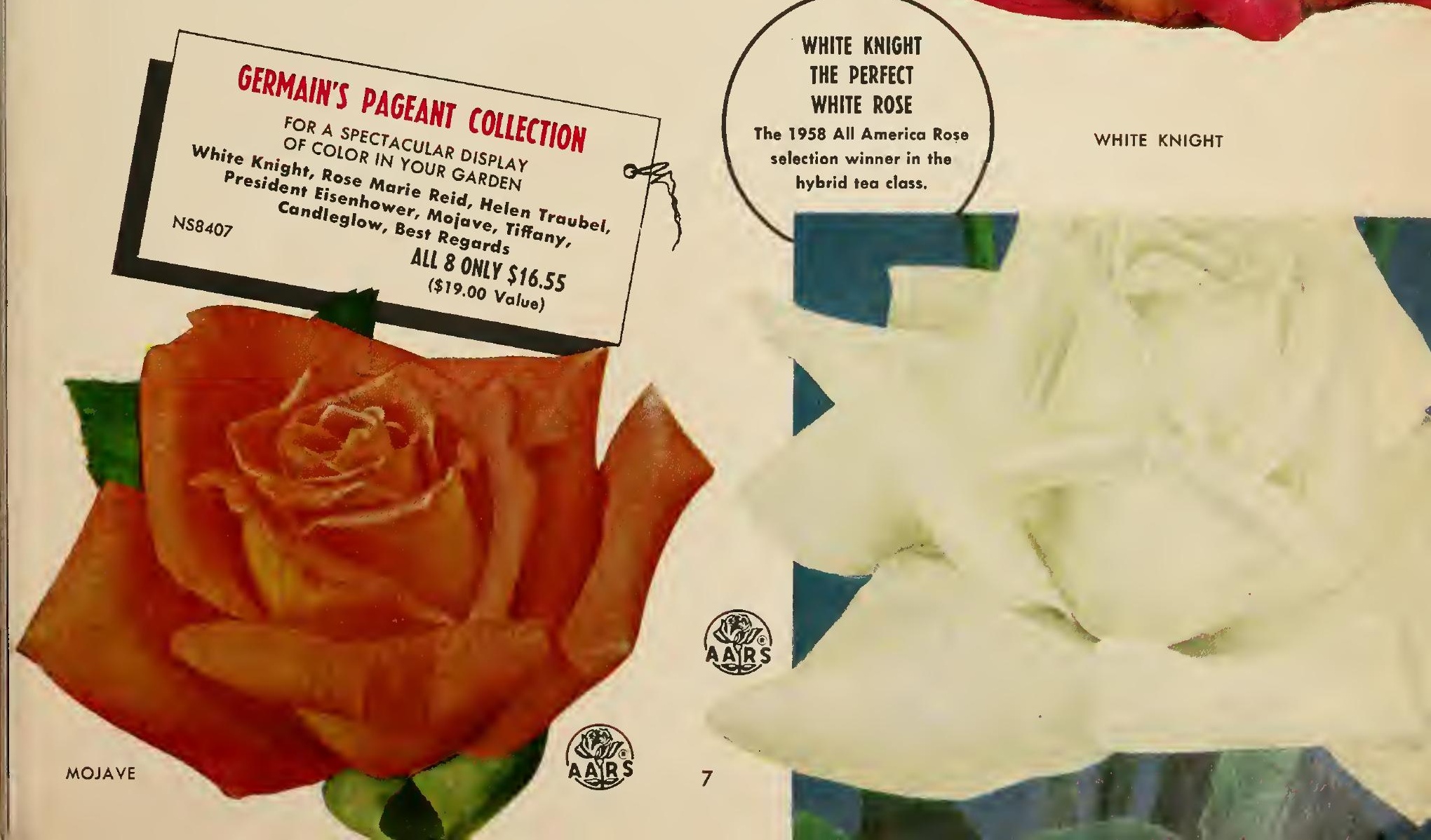




\section{Hit Parade of Hybrid}

rous raver
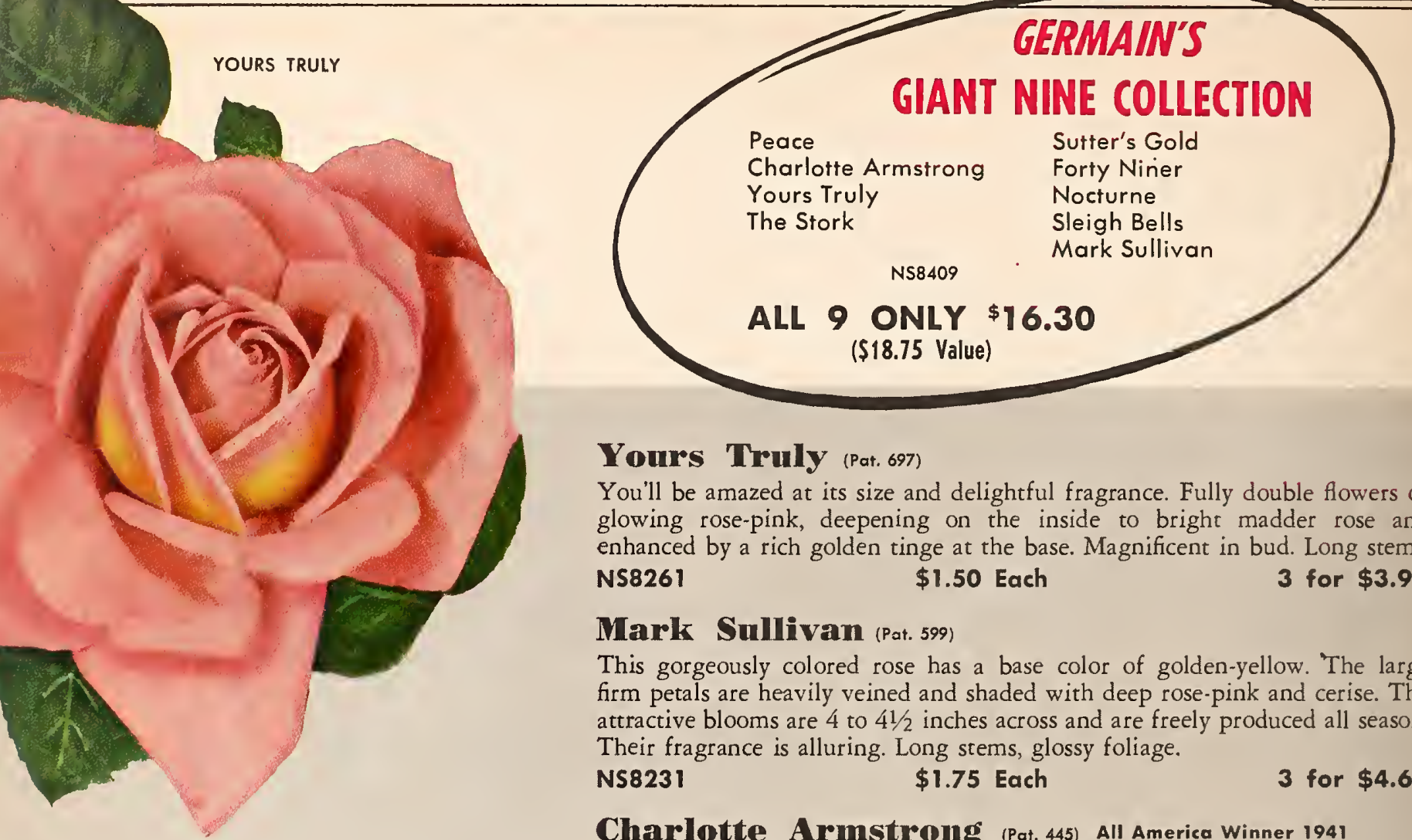

\section{Yours Truly (Par. 697)}

You'll be amazed at its size and delightful fragrance. Fully double flowers of glowing rose-pink, deepening on the inside to bright madder rose and enhanced by a rich golden tinge at the base. Magnificent in bud. Long stems.

NS8261

\section{Mark Sullivan (Pat. 599)}

This gorgeously colored rose has a base color of golden-yellow. 'The large firm petals are heavily veined and shaded with deep rose-pink and cerise. The attractive blooms are 4 to $41 / 2$ inches across and are freely produced all season. Their fragrance is alluring. Long stems, glossy foliage.

NS8231

$\$ 1.75$ Each

3 for $\$ 4.65$

Charlotte Armstrong (Pat. 445) All America Winner 1941

Lovely pointed buds of spectrum-red open to flowers of brilliant rose-pink, are long and are six inches in diameter. Petals edged with a silver line.

NS8207

$\$ 2.25$ Each

3 for $\$ 6.00$

Forty-Niner (Pat. 792) All America Winner 1949

Undoubtedly this is the most brilliant of all bicolors. Inside, the petals are a vivid Orient red, changing to cherry red with age. Outside, chrome to straw yellow. The buds are delightfully formed, opening into a large, well-shaped, pleasantly fragrant flower of 25 to 40 petals.

NS8217 \$2.25 Each

3 for $\$ 6.00$ 


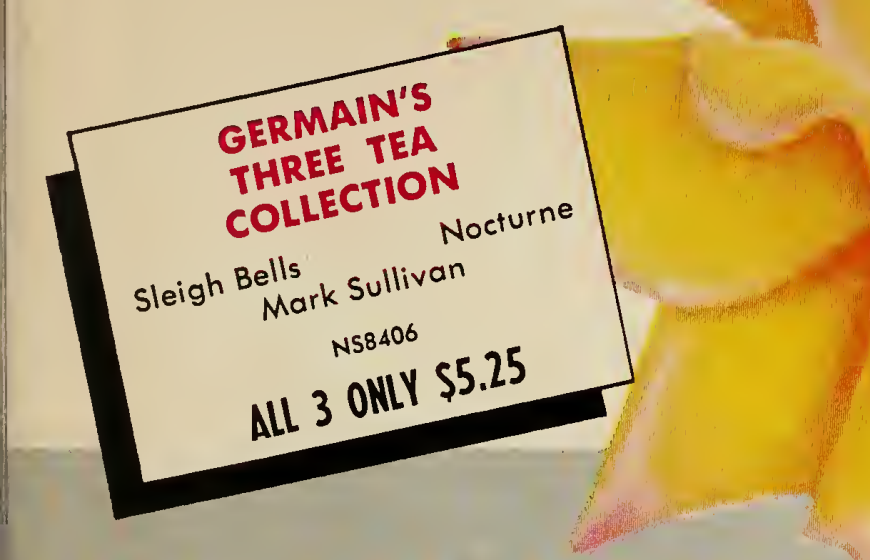

The Stork (Par. 1134)

Extra long streamlined buds of deep coppery salmon pink, which are produced on stiff stems. Flowers when open are of extremely large size due to the unusually large petals. NS8255

$\$ 2.00$ Each

3 for $\$ 5.25$

\section{Sutter's Gold (Par. 885)}

\section{All-America Award Winner for 1950}

Lovely deep burnt orange long pointed buds that are borne on long stems. As flowers open, the color changes to a golden yellow with lines of deep orange and tawny gold. Few roses can boast a plant so strong and vigorous.

\section{NS8254}

\section{\$2.25 Each}

3 for $\$ 6.00$

\section{Nocturne (Pat. 713)}

The color is bright cardinal-red with intriguing darker shadings of Chrysanthemum-crimson, opening to a somewhat lighter shade in hot weather. The large petals are richly textured, and there are plenty of them so that the flower lasts. All America Winner.
N58238
$\$ 2.25$ Each

3 for $\$ 6.00$
SLEIGH BELLS

\section{Peace (Pat. 591)}

One of the most glorious and sensational roses of all times. The big canary-yellow buds open to fiveinch flowers that turn to alabaster white with picote cerise edges. Shadings of color vary from flower to flower. The foliage is glossy green. Strong grower. All America Winner 1946.

\section{N58239 \\ $\$ 2.50$ Each \\ 3 for $\$ 6.60$}

\section{Sleigh Bells (Pat. 1004)}

Rose growers have been looking for a good white rose that would have free flowering qualities, and plenty of vigor. Sleigh Bells gives us the answer. The plant is a strong grower; with excellent foliage and fine long stems.

\section{NS8251 \$2.00 Each}

3 for $\$ 5.25$

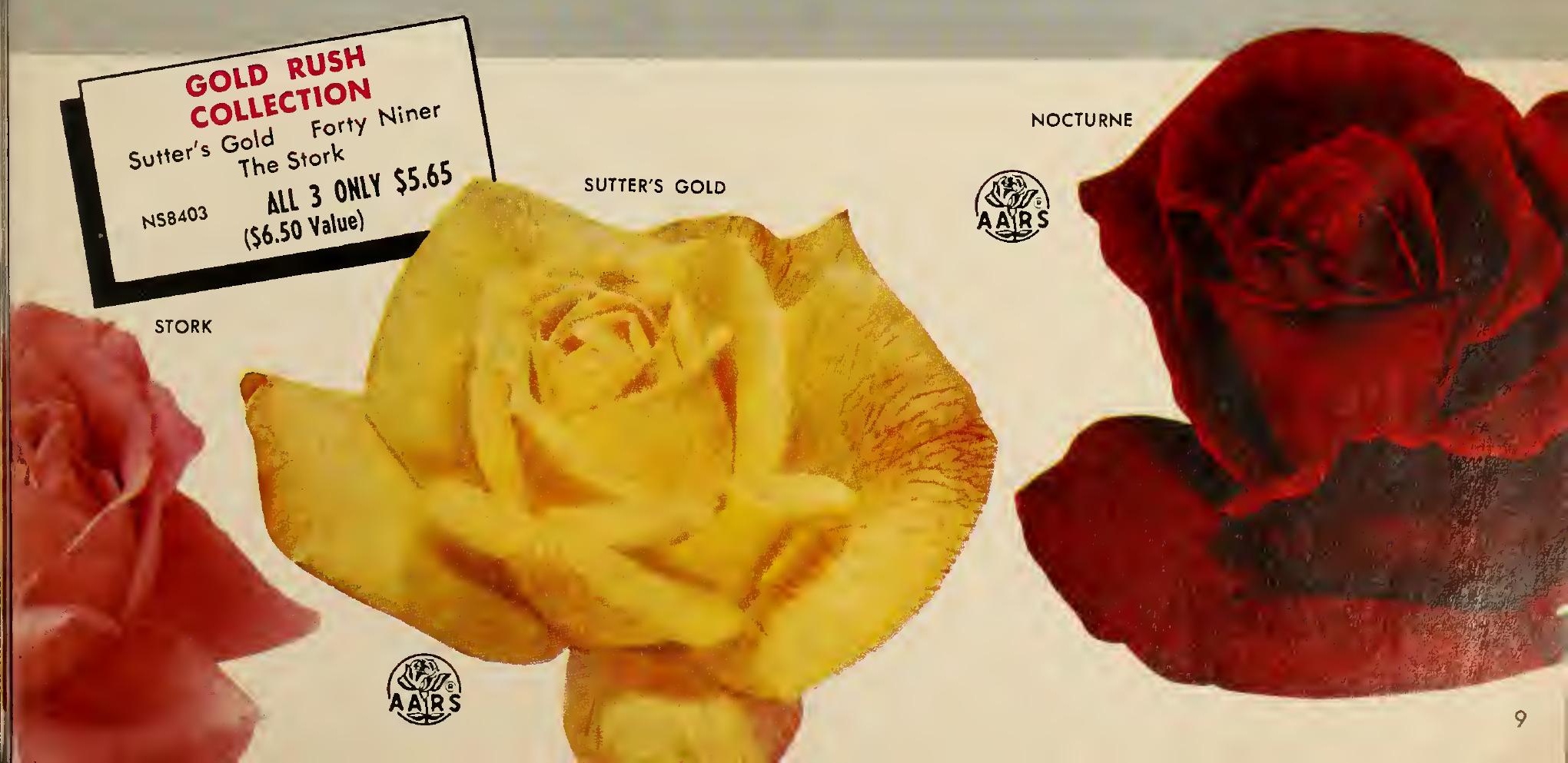




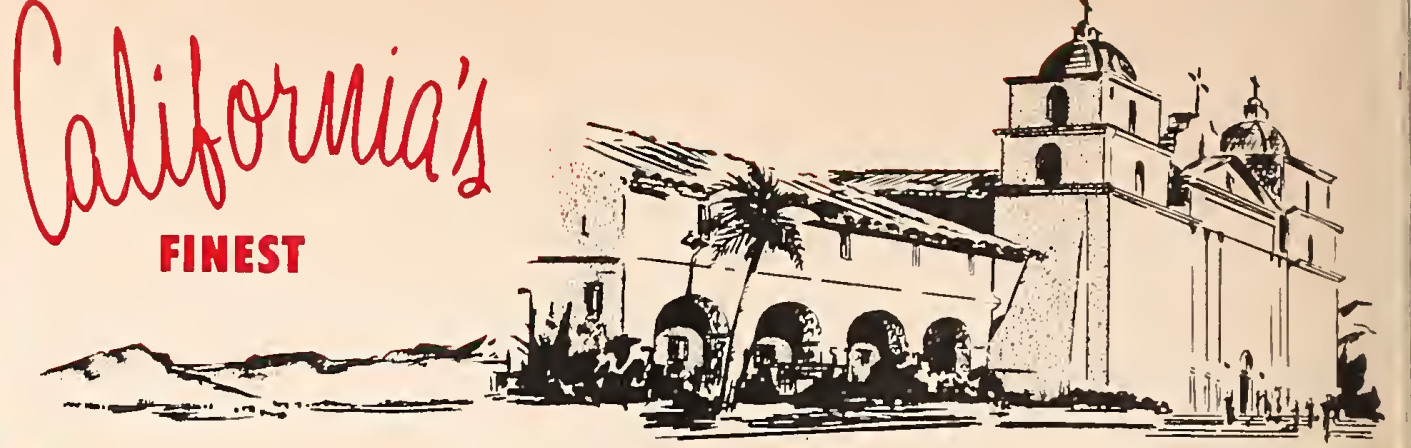

MISSION BELLS

\section{San Fernando (Pat. 785)} ALL AMERICA ROSE SELECTION WINNER 1948 A magnificent rose of glowing currant red with blooms of unusually heavy textureproudly borne on tall erect stems. Dark green, leathery foliage. So heavy is its pleasing perfume that just one bush will fill your whole garden with lovely fragrance.

\section{NS8248 \\ $\$ 1.75$ Each \\ 3 for $\$ 4.65$}

SaIr Luis Rey (Pat. 861)

A veritable treasure trove of golden loveliness. Long pointed buds of guinea gold opening to perfect flowers of satiny texture deepening at the base to rich cadmium yellow. Tea scented.

\section{NS8250 \$1.75 Each 3 for $\$ 4.65$}

\section{San Gabriel (Pat. 860)}

Long pointed buds of glowing salmon with a heavy overlay of tangerine orange and fire red. Distinct saffron yellow at the base of each petal. As the flower opens the petals reflex, showing all the beautiful coloring. Pleasing tea fragrance.

\section{NS8249 \$1.75 Each 3 for $\$ 4.65$}

Mission Bells (Pat. 923)

Mission Bells, the Top Hybrid Tea Rose Winner in the 1950 All America Selections is the first rose in ten years to retain its crown a second year.

An amazing rose! Excelling in size and vigor, it grows beautiful, heavily branched bushes with an abundance of huge roses, often 5 to 6 inches across. The large, tapering, salmon buds open to perfect, highcentered blooms of brilliant, clear salmonpink.

\section{NS8234 \$2.00 Each 3 for $\$ 5.25$}

\section{Capistrano (Pat. 922)}

All America Award Winner for 1950. Beautiful long tapered buds of bright cherry-red open to immense, long-lasting, perfect blooms of clear sparkling rose-pink; borne nearly always singly on long slender stem; ideal for cutting.

Heavy bushes with large, shiny green leaves. Its exceptionally rich rose fragrance adds much to its charm.

NS8205 \$2.00 Each 3 for $\$ 5.25$

\section{GERMAII'S MISSIOH TRAILS GERMAIN'S MISSION TRIO} COLLECTION COMPLETE MISSION SERIES FerMission Bells, Capistrano, Lan Luis Rey nando, San Gabriel, San LIY $\$ 8.00$ SAN GABRIEL

\section{WORLD FAMOUS} 3 OUTSTANDING ROSES THAT WILL PRO MAGNIFICENT IN YOUR GARD Gabriel San Fernando Lan Luis Rey
San All 3 ONLY $\$ 4.65$ (\$5.25 Value)

NS8421 
Cl. Charlotte Armstrong (Pat. 523)

Lovely pointed buds of spectrum-red open to flowers of brilliant rose-pink. The buds are unbelievably long and open to flowers six inches in diameter. Each petal is edged with a silver line.
NS8262
$\$ 2.50$ Each
3 for $\$ 6.60$

\section{Cl. Golden Showers}

First pillar and climbing rose in 16 yrs. to win the A.A.R.S. award. NS $8266 \quad \$ 2.75$ Each 3 for $\$ 7.20$

CHARLOTTE ARMSTRONC

PEACE
Cl. Peace (Pot. 932)

Climbing form of the world's leading rose-one of the most glorious and sensational roses of all times. Large yellow buds open to $5^{\prime \prime}$ flowers of alabaster white with picotee cerise edges.

$$
\begin{gathered}
\text { NS8271 } \$ 2.25 \text { Each } \\
3 \text { for } \$ 6.00
\end{gathered}
$$

Cl. High Noon (Pot. 704) An intense shade of clear, shining yellow. Glossy foliage. Almost thornless flower stems. Pillar type.

\section{N58269 \$2.50 Each 3 for $\$ 6.60$}

Cl. Heart's Desire(Pat. 663) Great dark red blooms of fine form and texture. Vigorous climber.

$$
\begin{gathered}
\text { NS8268 } \\
3 \text { for } \$ 4.75 \text { Each }
\end{gathered}
$$

SKYROCKET
COLLCTION
cl. Chrysler Imperial
ci. Golden Showers
cI. Charlotte Armstrong
NS8424
ALL ONLY \$6.95
(\$8.00 Value)
CELSTIAL
COLLCTION
CI. Golden Showers
Descanso Pillar
cI. San Fernando
NS8425
ALL 3 ONLY S6.30
(\$7.25 Value)

BLAZE

\section{Cl. Blaze}

One of the hardiest climbing varieties. A vivid, glowing scarlet that practically covers the plant all through the season

$$
\begin{gathered}
\text { NS8274 } \\
3 \text { for } \$ 3.90 \text { Each }
\end{gathered}
$$

BARGAIN OFFER
THREE FAVORITE
CLIMBERS
CI. Blaze cI. Hadley
CI. Talisman
NS8426
ALL 3 ONLY \$3.90
(\$4.50 Value)

Cl. San Ferinando (Pot. 1123)

A climbing form of the outstanding All America Winner. Has same currant red color and exquisite fragrance.
NS8275
$\$ 2.00$ Each
3 for $\$ 5.25$

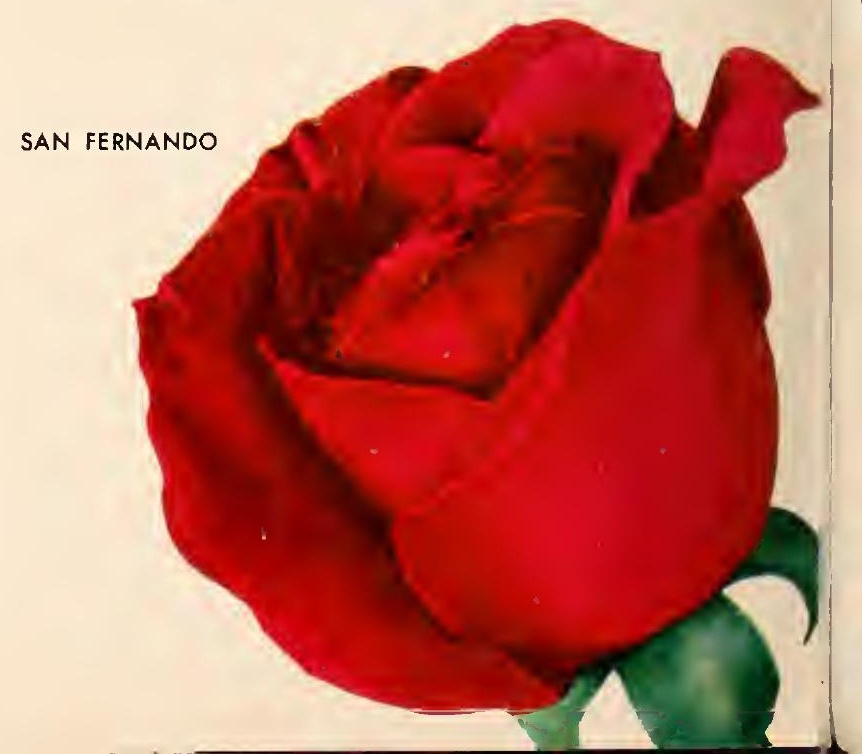




\section{Climbers}

\section{cl. Chrysler Imperial}

NOW the famous All America Winner Chrysler Imperial Rose in climbing form. Hundreds of long tapered crimson buds on vigorous canes, covering fences, walls or banks in vivid oxblood red. Unfolding even in adverse weather, the buds open to large, high-centered flowers measuring $41 / 2$ to 5 inches with 40 and 50 wide petals. The opening of each rose is a thrilling spectacle of changing, iridescent shades of red. The flowers are sweetly scented with true rose fragrance.

NS8263

$\$ 2.75$ Each

3 for $\$ 7.20$

\section{Talisman}

Produces great quantities of flowers which are a combination of gold, apricot, yellow and old rose. A vigorous climbing rose.

NS8287

$\$ 1.50$ Each

3 for $\$ 3.90$

\section{Mrs. Sam MeGredy (Pat. 374)}

Outstanding for its coppery orange flowers and buds. This variety unlike most climbers blooms profusely the first season after planting. The beautiful flowers are set off by the most luxurious handsome foliage imaginable.
NS8270
$\$ 1.75$ Each
3 for $\$ 4.65$

\section{cl. Hadley}

Well known rose in climbing form. Flowers are deep, velvety crimson. Fully double, well formed blooms are extremely fragrant.

NS8280

$\$ 1.50$ Each

3 for $\$ 3.90$

\section{You've Never}

Seen a Rose Like This Before-

Grows $8 \mathrm{Fi}$. High

Withou i Support

\section{Descanso Pillar (Pat. 943)}

\section{Spectacular Descanso Pillar Rose-}

Giant Clusters of Deep Coral Bloomson a Single Stem!

The all time top seller in a self-standing ever-blooming Pillar type rose. We regret that our previous limited supply only allowed a few of you to get this amazing rose. Now we have an abundant quantity of these world renowned bushes. However, to be sure, place your order NOW, as the demand is always so great for these sturdy, vigorous everbloomers. This amazing rose, the Descanso Pillar, is horticulture's most exciting new rose. Not a HYBRID TEA, not a FLORIBUNDA, not a GRANDIFLORA, not a TREE ROSE, but a remarkable new type rose that grows up to 8 FEET HIGH without any support of any kind-THE VERY FIRST YEAR!

You can pick a BOUQUET on one stem! Clusters of blooms are borne on single erect stems measuring 3 to 4 feet high. Long lasting as cut flowers, too!

NS8212

$\$ 2.50$ Each

3 for $\$ 6.60$ 


\section{Floribundas}

\section{MULTI-COLOR FLORIBUNDAS}

\section{Easter Parade (Pat. 1200)}

It is remarkable to watch this glorious Floribunda go through such an amazing transition of colors. At first the buds are bright golden yellow. Then, while opening, the upperside of the petals becomes edged with salmon pink and cerise, remaining yellow on the underside. And finally, Easter Parade emerges a gorgeous light crimson rose with delicate yellow tonings.
NS8213
$\$ 2.00$ Each
3 for $\$ 5.25$

\section{Circus (Pat. 1382}

1956 A.A.R.S. WINNER-Only Multicolor rose ever to win.

Floribunda rose actually changes color as the buds open into fully blown flowers. At the start the buds are rich yellow and red, then as if by magic, exciting orange-buff appears, flushed with apple blossom pink, and finally to the gayest red you've ever seen. The high-centered blooms are fragrant and long lasting.

\section{NS8210 \$2.50 Each}

3 for $\$ 6.60$

\section{Mexicali Rose (Pat. 1486)}

This truly spectacular new Floribunda, acclaimed one of the most unusual developed in this century, introduces gay, vivid colorsbright as a Fiesta-to achieve one of the most dazzling displays ever created in the rose world!

N58233 \$2.50 Each 3 for $\$ 6.60$

MEXICALI ROSE

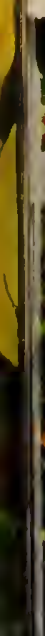

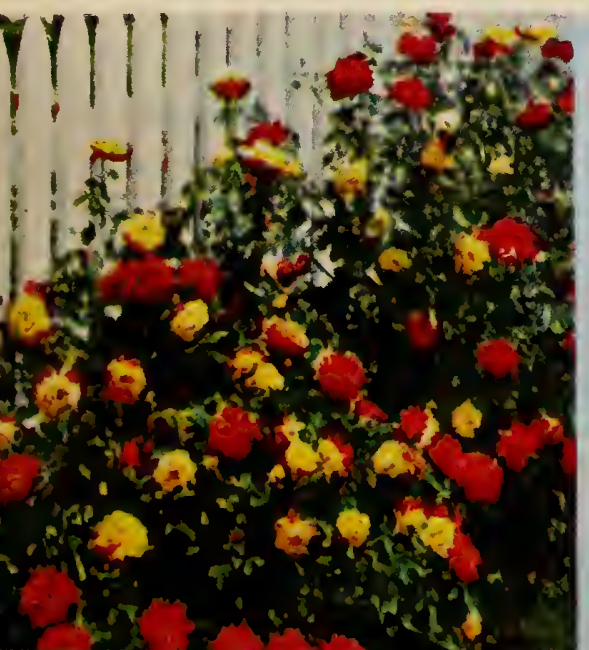

\section{FAVORITE FLORIBUNDA COLLECTION \\ AMIGO \\ CHINA DOLL \\ FLORADORA \\ MARGO \\ KOSTER \\ SNOWBIRD \\ NS8428}

ALL 5 ONLY $\$ 7.20$

(\$8.25 Value)
Chima Doll (Pat. 678)

The bright pink flowers grow in a multitude of clusters. The vast profusion of blooms so covers the plant that the foliage cannot be seen. Ideal for a low hedge. NS8208 \$2.25 Each 3 for $\$ 6.00$ 


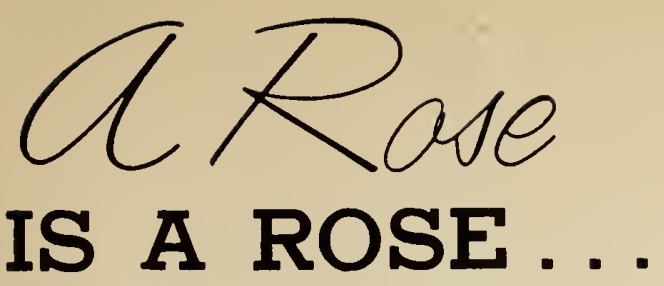

The Rase holds the distinction of being the favorite flower of the American gardener-an honor it has maintained the world over.

The Rose has been found blooming in its wild state on every continent of the world north of the equator. In ancient times, the Greeks cultivated roses for medicinal purposes as well as used the petals for perfume.

The Rase varieties that were popular in American and European gardens more than 100 years ago are still found in commercial avenues today.

The Rase has never lost its appeal-indeed, its popularity has steadily increased.

Consequently, the spectacular success of Germain's in the hybridizing, development and marketing of prize winning roses has commanded the attention of home gardeners and florists everywhere.

Distinguished rcses offered by Germain's include the Cl. Queen Elizabeth, Descanso Pillar, Best Regards, The Stork, Cl. San Fernando, Amigo, Cl. Chrysler Imperial, Sun Valley, Easter Parade, Las Vegas, Mexicali, Rose Marie Reid, Candleglow, Yours Truly, San Luis Rey, and the San Gabriel. In the last ten years alone, of the many roses Germains has introduced, seven have been winners of the All-American Rose Selections, Incorporated-the Hall of Fame of the rose world. These roses have included:

San Fernando, 1948

Chrysler Imperial, 1953

Mission Bells, 1950

Queen Elizabeth, 1955

Capistrano, 1950

Golden Showers, 1957

One of the newest and most sensational roses in the Germain's family has been the Merry Widow-a rose of such breathtaking beauty

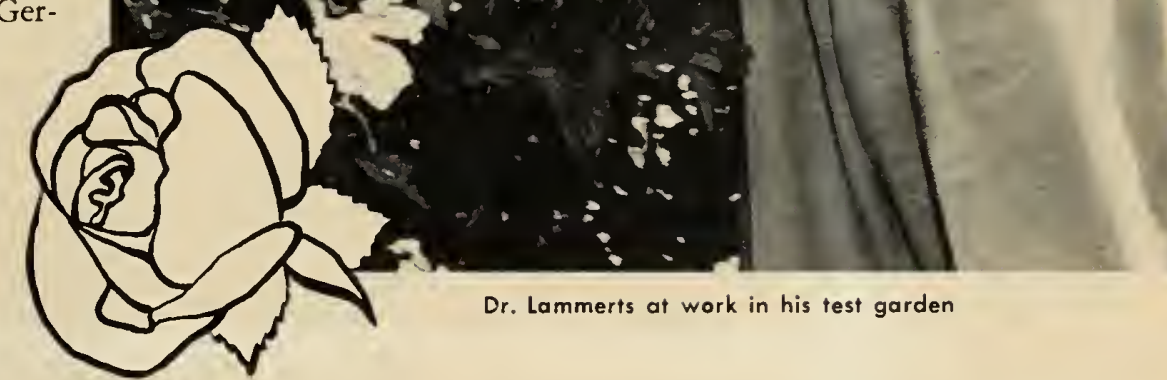
that it has become a favorite of rose lovers from coast to coast almost overnight.

Furthermore, the immediate rose future for Germain's and for gardeners everywhere promises to be the most exciting in the history of the 87-year-old company according to Dr. Walter E. Lammerts, Germain's noted hybridizer.

Called the "father of scientific rose breeding," Dr. Lammerts has long been recognized for his outstanding achievements in the development of prize winning roses. Even before his interest and success in the world of roses, Dr. Lammerts had achieved fame in commercial laboratories and at the University of California, Los Angeles, for his work with different species of fruit.

At the present, Dr. Lammerts is spending all of his time on rose breeding at Livermore, California. His goal is to develop roses that will be rust resistant; mildew resistant; blackspot resistant; non-fading and winter hardy.

He is getting closer and closer to this goal all the time.

Many people still think of roses as they were 25 years agosuperbly beautiful, but far too exacting for the average gardener. This isn't the case any longer, Dr. Lammerts says. Vari-

eties of roses are now being produced which are as easy to plant and take no more care than any other popular flower.

Through the efforts of men like Dr. Lammerts, it is becoming increasingly easy to achieve classic rose gardens at home with minimum fuss and bother.

Just recently one of Dr. Lammerts' prize creations-the beautiful pink Queen Elizabeth rose-was awarded the coveted Gertrude M. Hubbard Gold Medal of the American Rose Society. This award is made only once every five years by the Society to the originator of the best American rose during that period.

Other creations of Dr. Lammerts include the famous Charlotte Armstrong, Chrysler Imperial, Mirandy, Taffeta, High Noon, Debonaire, The Chief, Golden Showers, Merry Widow and many others.

Germain's roses are reknowned throughout the nation. Their beauty, vitality and abundant bloom stem naturally from California's rich soil, milder climate and longer growing season. This means a more sturdy, beautiful rose for gardens in any climate.

Germain's is truly a symbol of highest quality in roses. 


\section{GERMAIN'S HIGHEST QUALTY LAWN SEFD \\ THE ANSWER TO ALL OF YOUR LAWN SEED PROBLEMS}

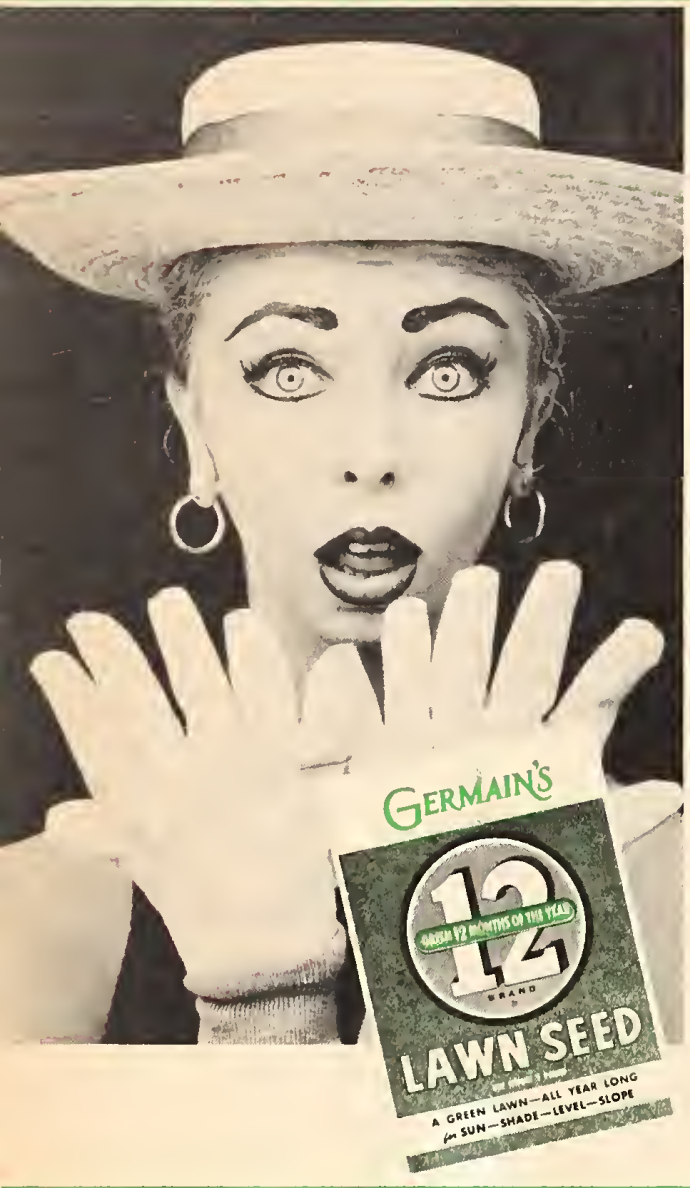

\section{DIFFERENT LAWH SEED VARIETIES}

. blended into one all-purpose perennial mixture ... GERMAIN'S 12-BRAND! Whether your lawn is in the sun or shade (or both!), on level or sloping ground (or both!), Germain's 12-Brand Lawn Seed will give you a lush green lawn, 12 months of the year. 12-Brand, the all-purpose mixture, is scientifically blended to give you the best lawn under all conditions. This amazing formula of newest grasses produces a GREEN LAWN ALL YEAR LONG!

No. CSOO

1 Lb. Carton- $\$ 1.80$

5 Lb. Carton- $\$ 7.85$ 25 Lbs. $-\$ 35.00$

\section{THE MIRACLE LAWN} GERMAIN'S BEAUTILAWN BRAND DICHONDRA

Scarified for Quick Germination Germain's Beautilawn Brand Dichondra seed will produce an amazing dark green lawn of small velvety leaves. Grows well in sun or shade providing a strong healthy turf that will not mat.

After starting, the maintenance of your Germain's Beautilawn Brand Dichondra Lawn is very slight. It will choke back bermuda and other bothersome weeds. And-it will take the roughest usage that you can give it. You can plant Germain's Beautilawn Brand Dichondra right in your old lawn and within two years you will have a dichondra carpet. When planting a new Germain's Beautilawn Brand Dichondra lawn it should be sown with clover for best results.

No. CS08 I Lb. Carton-\$4.95-Plant at the rate of $1 / 4 \mathrm{Lb} .101000 \mathrm{sq} . \mathrm{ft}$.

Easy to Use-No Waste Convenient Shaker-Top Canister

GERMAIN'S BEAUTILAWN BRAND DICHONDRA

Save time, money, and cut down waste with this NEW package of Germain's Beautilawn Brand Dichondra. Finest quality dichondra seed.

No. C508-4 ox. 5haker-Top (1,000 sq. ft. coverage) $\$ 1.45$

EASIEST TO GROW GERMAIN'S BRAND WHITE CLOVER

(Trifolium Repens)

America's favorice lawn seed. Easiest to grow. Used extensively as a nurse crop for many fine lawn seeds.

The brightest green rounded leaves will give your lawns a sparkling appearance. Excellent to use with dichondra.

Plant at the rate of $1 \mathrm{Lb}$. to $200 \mathrm{Sq}$. Ft.

No. 6512

$1 / 2$ Lb. $-90 c$

1 เb. $-\$ 1.70$

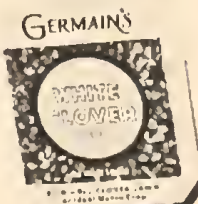

THE MIRACLE LAWH

Coated 16 Times Larger for Easy Planting

GERMAIN'S SENSATIONAL-NEW KOLORCOAT* DICHONDRA * Reg.

- Deep, Rich Green All Year S. Pat. Off.

Requires No Mowing - Chokes Back Bermuda - Resists Rough Usage - Thrives in Sun and Shade

Dichondra is a low-growing American plant, native to the south. eastern part of the United States, from Virginia south. It is known botanically as Dichondra Repens or D. Repens var. Carolinensis. Germain's Kolorcoat Dichondra makes a dense sod by means of runner-like stems, growing very close to the ground, but never forms a thick mat like bermuda grass. The kidney-shaped leaves, about $1 / 4$ in. wide, and seldom over $11 / 2$ in. tall have a rich dark velvety-green color. Dichondra is tough in texture and hard usage will not injure the strong turf or mar its beautiful appear. ance.

In mild climates dichondra can be started any time of the year. Since summer is the best growing season for Dichondra, spring or early summer planting gives quickest results. When planting during the colder months a nurse crop is suggested.

In the East or Middle West we recommend spring or early sum. mer planting. This allows enough time to develop a strong root system for the plants to make seed. When the foliage and top growth is hurt by rigorous weather the lawn will then renew itself from the roots and self-sown seeds.

No. CS04 JUMBO (6" $\left.\mathrm{x} 99^{\prime \prime}\right)$ Package Germain's Kolor- ONLY $\$ 1.00$ coat Dichondra Lawn Seed (Contains enough seed to cover 300 sq. fr.

No. C504 I Lb. Carton Germain's Kolorcoat Dichondra ONLY $\$ 2.85$ Lawn Seed (Contains enough seed to cover 1,000 sq. ft.)
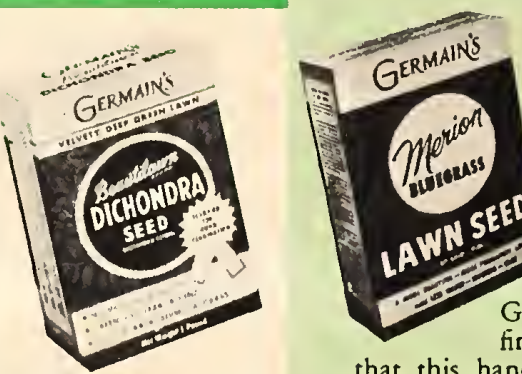

\section{GERMAIN'S BRAND} MERION KENTUCKY BLUEGRASS

A MORE BEAUTIFUL, MORE PERMANENT LAWN - DISEASE RESISTANT • DROUGHT RESISTANT - sTANDS CLOSE - economical MOWING

Less Watering-Mowing-Care

Germain's Brand Merion Kentucky Bluegrass is the finest of all lawn grasses. Exhaustive tests have proved that this handsome lawn grass will stand long, hot, dry spells better than any other bluegrass. Forget about mowing too close - just set your mower for the fine turf effect you've always wanted and go ahead. Get that golf green appearance with Germain's Brand Merion Kentucky Bluegrass.

The thrilling apple green color of Germain's Brand Merion Kentucky Bluegrass will provide a luxurious velvety background to your entire landscape. And-it takes less water-mowingand care to have the neighborhood's most beautiful lawn.

Bothersome weeds such as crabgrass, etc, are quickly crowded out of your lawn by this healthy hardy bluegrass. The strong root system developed by Germain's Brand Merion Kentucky Bluegrass spreads the grass evenly and is so hardy that yearly reseeding is not necessary.

Economical? Why, you can plant your whole lawn area with Germain's Brand Merion Kentucky Bluegrass at less than 10 per sq ft. $1 \mathrm{Lb}$. will cover approximately 750 sq. ft.

No. C502 $\quad 1 / 2$ Lb. Carton-\$2.30

1 Lb. Carton $-\$ 4.10$

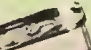

DICHONDRA BLENDED WITH WHITE CLOVER Shake-Top Canister

Germain's Brand Clover makes an ideal nurse crop for Dichondra. Now mixed in the right proportions to start a fine Dichondra lawn.

No. CS10-8 oz.-5haker-Top Canister

(250 sq. ft. coverage).

$\$ 2.00$ 
NAME

ADDRESS

\section{CITY}

ZONE

STATE

$\square$ If you have moved since your last order please indicate former city.

$\square$ If merchandise is to be sent to another ad. dress please fill in name and complete address.

NAME

ADDRESS

CITY

Please Print ar Type
CUSTOMER SERVICE-Usually anather variety af same calar and quality will be sent shauld we be aut of ane yau arder. If yau da nat wish this service mark " $X$ " in bax at right.

NON-WARRANTY. Germain's Inc. gives na warranty, express ar implied as to the praductiveness of seeds, bulbs ar plants if sells and will nat be in any way respansible far the crap. Our liability in all instances is limited ta the purchase price of the seed, bulbs, ar plants.

TERMS: Send remittance in full with your arder. We pre-pay pastage. WE DO NOT SHIP C.O.D.

DO NOT WRITE IN SPACE BELOW
AMOUNT ENCLOSED

$\$$

$\square$ Check $\square$ Money Order

Calif. custamers please add $4 \%$ Sales Tax

\begin{tabular}{|c|c|c|c|c|c|c|c|c|c|c|c|}
\hline Quan. & $\begin{array}{l}\text { Cat. } \\
\text { No. }\end{array}$ & Item and Price & TOTAL & Quan. & $\begin{array}{c}\text { Cat. } \\
\text { No. }\end{array}$ & Item and Price & TOTAL & Quan. & $\begin{array}{l}\text { Cat. } \\
\text { No. }\end{array}$ & Item and Price & TOTAL \\
\hline \multirow{2}{*}{\multicolumn{4}{|c|}{$\begin{array}{l}\text { ROSE COLLECTIONS } \\
\text { (Ioch Colloctlon Must } \\
\text { so Shippod To One Address) }\end{array}$}} & & MS1236 & $\begin{array}{l}\text { MojAVE } \\
\$ 2.75 \text { ea.; } 3 \text { for } \$ 7.20\end{array}$ & & & NS1264 & $\begin{array}{l}\text { SHOWBIRD } \\
\$ 1.50 \text { ea.; } 3 \text { for } \$ 3.90\end{array}$ & \\
\hline & & & & & MS1237 & $\begin{array}{l}\text { MoNTEzuma } \\
\$ 2.75 \text { ea.; } 3 \text { for } \$ 7.20\end{array}$ & & & MS1273 & $\begin{array}{l}\text { WNITE BDUQUET } \\
\$ 2.50 \text { ea.; } 3 \text { for } \$ 6.60\end{array}$ & \\
\hline & NST 400 & $\begin{array}{l}\text { TRIPLE TREAT CDLLECTION } \\
3 \text { roses only } \$ 6.75\end{array}$ & & & NSI23I & 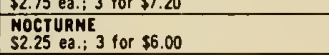 & & & NSE293 & $\begin{array}{l}\text { FLORADORA } \\
\text { F1.50 ea.; } 3 \text { for } \$ 3.90 \\
\end{array}$ & \\
\hline & NSO 402 & $\begin{array}{l}\text { GERMAIN'S ROYAL COLLECTIDH } \\
3 \text { roses only } \$ 6.50\end{array}$ & & & NSI230 & $\begin{array}{l}\text { PEACE } \\
\$ 2.50 \text { ea.: } 3 \text { for } \$ 6.60\end{array}$ & & \multicolumn{4}{|c|}{ CLIMBING AND PILLAR ROSES } \\
\hline & NSQ403 & $\begin{array}{l}\text { SDLD RUSH CDLLECTIOA } \\
3 \text { roses only } \$ 5.65\end{array}$ & & & NSB240 & $\begin{array}{l}\text { PICTURE } \\
\$ 1.50 \text { ea.; } 3 \text { for } \$ 3.90\end{array}$ & & & HS1212 & $\begin{array}{l}\text { OESCANSO PILLAR } \\
\$ 2.50 \text { ea.: } 3 \text { for } \$ 6.60\end{array}$ & \\
\hline & NSQ40S & $\begin{array}{l}\text { GERMAIN'S MELDOY COLLECTIOH } \\
7 \text { roses only } \$ 15.60\end{array}$ & & & NS1242 & 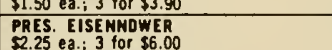 & & & MS0262 & $\begin{array}{l}\text { CL CHARLDTEE ARMSTRONG } \\
\$ 2.50 \text { ea.; } 3 \text { for } \$ 6.60\end{array}$ & \\
\hline & NSWAOO & $\begin{array}{l}3 \text { TEA COLLECTIDH } \\
3 \text { roses only } \$ 5.25\end{array}$ & & & NS1243 & 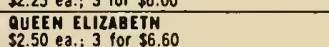 & & & AS8263 & $\begin{array}{l}\text { CLL CMRYSLER MMPERIAL } \\
\$ 2.75 \text { ea; } 3 \text { for } \$ 7.20\end{array}$ & \\
\hline & NSMOT & $\begin{array}{l}\text { GERMAIN'S PAGEANT COLLECTION } \\
8 \text { roses only } \$ 16.55\end{array}$ & & & NS1246 & 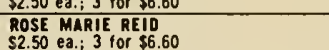 & & & HS1265 & $\begin{array}{l}\text { CL. GOLOEN SNOWERS } \\
\$ 2.75 \text { ea.; } 3 \text { for } \$ 7.20\end{array}$ & \\
\hline & \begin{tabular}{l|l} 
NSWOOS \\
\end{tabular} & $\begin{array}{l}\text { GERMAIN'S GIANT NINE COLLECTIDN } \\
9 \text { roses only } \$ 16.30\end{array}$ & & & NSE247 & $\begin{array}{l}\text { \$2.50 ea.; } 3 \text { for } \$ 6.60 \\
\text { ROUHOELAY } \\
\$ 2.50 \text { ea.; } 3 \text { for } \$ 6.60 \\
\end{array}$ & & & HS6251 & $\begin{array}{l}\text { CL. MEART'S DESIRE } \\
\$ 1.75 \text { ea.; } 3 \text { for } \$ .65 \\
\end{array}$ & \\
\hline & NSM10 & $\begin{array}{l}\text { MARDI GRAS COLLECTION } \\
4 \text { roses only } \$ 9.20\end{array}$ & & & NSE240 & 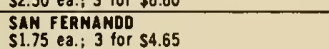 & & & HSO269 & $\begin{array}{l}\text { CL. NIGN NOON } \\
\$ 2.50 \text { ea.; } 3 \text { for } \$ 6.60 \\
\end{array}$ & \\
\hline & NSM12 & $\begin{array}{l}\text { GERMAN'S GRANOIFLORA COLLECTION } \\
6 \text { roses Only \$13.05 }\end{array}$ & & & HSE249 & $\begin{array}{l}\$ 1.75 \text { ea.; } 3 \text { for } \$ 4.65 \\
\text { SAN GABREIEL } \\
\$ 1.75 \text { ea.: } 3 \text { for } \$ 4.65\end{array}$ & & & NS8270 & $\begin{array}{l}\text { CL. MARS. SAM MeGREDY } \\
\text { \$1.75 ea.; } 3 \text { for } \$ \text { \$. } 65\end{array}$ & \\
\hline & NSW14 & $\begin{array}{l}\text { A.A.R.S. WIMAER R LORIBUMDA COLL. } \\
\text { S roses Only } \$ 10.00\end{array}$ & & & NSO250 & $\begin{array}{l}\text { SAN LU. : } 3 \text { REY } \$ 4.65 \\
\text { S1.75 ea.; } 3 \text { for } \$ 4.65\end{array}$ & & & HSO271 & $\begin{array}{l}\text { CL. PEACE } \\
\$ 2.25 \text { ea.; } 3 \text { for } \$ 6.00\end{array}$ & \\
\hline & NSM15 & $\begin{array}{l}\text { GERMAIN'S CELEBRITY COLLECTION } \\
4 \text { roses only } \$ 9.15\end{array}$ & & & NSE251 & $\begin{array}{l}\text { SLEEGH BELLS } \\
\text { \$2.00 ea.; } 3 \text { for } \$ 5.25\end{array}$ & & & NS8274 & $\begin{array}{l}\text { CL. BLAZE } \\
\$ 1.50 \text { ea.; } 3 \text { for } \$ 3.90\end{array}$ & \\
\hline & NSW16 & $\begin{array}{l}\text { NIT PARADE EKTRA } \\
4 \text { roses only } \$ 7.40\end{array}$ & & & NS0253 & $\begin{array}{l}\text { S2.00 ea.; } 3 \text { for } \$ 5.25 \\
\text { SUN VALLEY RSSE } \\
\$ 2.50 \text { ea.; } 3 \text { for } \$ 6.60\end{array}$ & & & MS127S & $\begin{array}{l}\text { CL. SAN FERMANOD } \\
\$ 2.00 \text { ea.; } 3 \text { for } \$ 5.25\end{array}$ & \\
\hline & NSM11 & $\begin{array}{l}\text { WISNING WELL COLLECTIDN } \\
3 \text { roses only } \$ 5.45\end{array}$ & & & HS1254 & 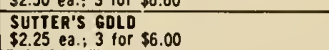 & & & MS1280 & $\begin{array}{l}\text { CL. MAOLEY } \\
\$ 1.50 \text { ea.; } 3 \text { for } \$ 3.90\end{array}$ & \\
\hline & NSH2O & $\begin{array}{l}\text { RDSE BOWL CDLLECTION } \\
10 \text { roses only } \$ 12.95\end{array}$ & & & NSE2SS & $\begin{array}{l}\text { INE STDRK } \\
\$ 2.00 \text { eaR; } 3 \text { for } \$ 5.25\end{array}$ & & & MS1207 & $\begin{array}{l}\text { CL. TALISMAM } \\
\$ 1.50 \text { ea.; } 3 \text { for } \$ 3.90\end{array}$ & \\
\hline & NSO421 & $\begin{array}{l}\text { GERMAIN'S MISSIDN TRID } \\
3 \text { roses only } \$ 4.65\end{array}$ & & & MS1256 & $\begin{array}{l}\text { TIFFANY } \\
\$ 2.50 \text { ea.; } 3 \text { for } \$ 6.60\end{array}$ & & \multicolumn{4}{|c|}{ MINIATURE ROSES } \\
\hline & NS1422 & GERMAIN'S MISSIDN TRAILS COLL. & & & \begin{tabular}{l|l} 
NS1260 \\
Nons
\end{tabular} & $\begin{array}{l}\$ 2.50 \text { ea.; } 3 \text { for } \$ 6.60 \\
\text { WNITE KNIGNT }\end{array}$ & & & NSOASS & $\begin{array}{l}\text { DE LUKE MINIATURE RDSE COLL. } \\
5 \text { roses only } \$ 8.75\end{array}$ & \\
\hline & MS1424 & 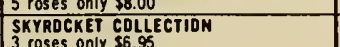 & & & 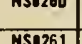 & $\begin{array}{l}\text { \$3.00 ea.; } 3 \text { for } \$ 7.95 \\
\text { YouRs TRULY }\end{array}$ & & & NSBAS6 & \begin{tabular}{|l|} 
INTRDDUCTOPY COLLECTION \\
3 roses OnIy $\$ 5.00$
\end{tabular} & \\
\hline & NSW 25 & 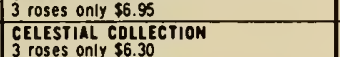 & & & NSI261 & $\begin{array}{l}\text { YDURS TRULY } \\
\text { S1.50 ea.; } 3 \text { for } \$ 3.90 \\
\end{array}$ & & & NSBST & $\begin{array}{l}\text { CLLMBIME MIINATURE COLLECTIOH } \\
3 \text { roses OnIY } \$ 5.75\end{array}$ & \\
\hline & MSW & & & & MS1207 & \begin{tabular}{|l} 
TEKAS CERTEWNIIL \\
S1.50 ea.; 3 for $\$ 3.90$ \\
\end{tabular} & & & NSQ459 & $\begin{array}{l}\text { TOM TMUMB MIIIATURE ROSE COLL. } \\
5 \text { roses only S5.75 }\end{array}$ & \\
\hline & NS1427 & $\begin{array}{l}3 \text { COSSE OONYY } \$ 3.90 \\
\text { CLIMBING QUARTETTE COLLECTIOH }\end{array}$ & & & NS124 & $\begin{array}{l}\text { COUNTESS VANDAL } \\
\$ 1.50 \text { ea.; } 3 \text { for } \$ 3.90\end{array}$ & & & \begin{tabular}{|l|l} 
NSBA63 \\
\end{tabular} & 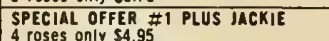 & \\
\hline & & 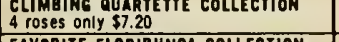 & & & NSO20S & $\begin{array}{l}\text { CRIMSON ELORY } \\
\text { \$1.50 ea.; } 3 \text { for } \$ 3.90\end{array}$ & & & NSBAS & & \\
\hline & NSW & $\begin{array}{l}\text { FAYORITE FLOAIBUMOA COLLECTION } \\
5 \text { roses only } \$ 7.20\end{array}$ & & & NS1200 & $\begin{array}{l}\text { ECLPSE } \\
\$ 1.50 \text { ea.; } 3 \text { for } \$ 3.90\end{array}$ & & & & 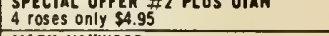 & \\
\hline & NSM20 & $\begin{array}{l}\text { MULTTCOLOR FLRIBUMDA COLLECTIOA } \\
3 \text { roses OnIY } \$ 6.10\end{array}$ & & & NS8290 & ETOILE OE MOLLAHO & & & NSO4AO & $\begin{array}{l}\text { MARY NAYWOOD } \\
\$ 1.25 \text { ea.: } 3 \text { for } \$ 3.50 ; 12 \text { for } \$ 12.50\end{array}$ & \\
\hline & NSD 430 & 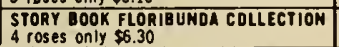 & & & & $\$ 1.50$ ea.; 3 for $\$ 3.90$ & & & NSB441 & $\begin{array}{l}\text { WHITE ASTER } \\
\text { s1.25 ea.; } 3 \text { for } \$ 3.50 ; 12 \text { for } \$ 12.50\end{array}$ & \\
\hline \multicolumn{4}{|c|}{ ROSE BUSHES-HYBRID TEA } & \multicolumn{4}{|c|}{ ROSE BUSHES-FLORIBUNDA } & & NSB 442 & $\begin{array}{l}\text { CIMOERELLA } \\
\$ 1.25 \text { ea.; } 3 \text { for } \$ 3.50 ; 12 \text { for } \$ 12.50\end{array}$ & \\
\hline & NS5201 & $\begin{array}{l}\text { GEST REGAROS } \\
\$ 1.50 \text { ea.; } 3 \text { for } \$ 3.90\end{array}$ & & & NSL200 & $\begin{array}{l}A M 1.50 \\
\$ 1.50 \text { ea.; } 3 \text { for } \$ 3.90\end{array}$ & & & NSE443 & $\$ 2.00$ ea.; 3 for $\$ 5.25 ; 12$ for $\$ 20.00$ & \\
\hline & NS1203 & $\begin{array}{l}\text { BUCCANEER } \\
\$ 2.50 \text { ea.; } 3 \text { for } \$ 6.60 \\
\end{array}$ & & & NSS! 208 & 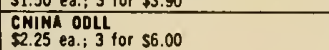 & & & MSO444 & 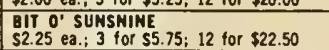 & \\
\hline & NS1204 & $\begin{array}{l}\text { CANOLEGLOW } \\
\$ 1.75 \text { ea.; } 3 \text { for } \$ 4.65\end{array}$ & & & MS1210 & $\begin{array}{l}\text { CIRCUS } \\
\$ 2.50 \text { ea.; } 3 \text { for } \$ 6.60\end{array}$ & & & NS:445 & $\begin{array}{l}\text { LITTLE BUCKARO0 } \\
\$ 2.00 \text { ea.; } 3 \text { for } \$ 5.25 ; 12 \text { for } \$ 20.00\end{array}$ & \\
\hline & NS1205 & $\begin{array}{l}\text { CAP ISTRANO } \\
\$ 2.00 \text { ea.; } 3 \text { for } \$ 5.25\end{array}$ & & & HSE213 & $\begin{array}{l}\text { EASTER PARAOE } \\
\$ 2.00 \text { ea.; } 3 \text { for } \$ 5.25\end{array}$ & & & NSB447 & $\begin{array}{l}\text { FROSTY } \\
\$ 2.00 \text { ea.; } 3 \text { for } \$ 5.25 ; 12 \text { for } \$ 20.00\end{array}$ & \\
\hline & NS1206 & $\begin{array}{l}\text { CARROUSEL } \\
8.00 \text { ea. } 3 \text { for } \$ 5.25\end{array}$ & & & MSO210 & \begin{tabular}{|l|l|l} 
Fisstow \\
$\$ 2.00$ ea.: 3 for $\$ 5.25$
\end{tabular} & & & MSBAAB & $\begin{array}{l}\text { CLIMBIIG MAGC WALO } \\
\$ 2.25 \text { ea.; } 3 \text { for } \$ 5.75 ; 12 \text { for } \$ 22.50\end{array}$ & \\
\hline & NS1207 & $\begin{array}{l}\text { CMARLDTTE ARMSTROHG } \\
\$ 2.25 \text { ea.; } 3 \text { for } \$ 6.00\end{array}$ & & & NS1210 & $\begin{array}{l}\text { FUSILER } \\
\$ 2.50 \text { ea.; } 3 \text { for } \$ 6.60\end{array}$ & & & NSBAQ & $\begin{array}{l}\text { CLIMBING IACKIE } \\
\$ 2.25 \text { ea: } 3 \text { for } \$ 5.75 ; 12 \text { for } \$ 22.50\end{array}$ & \\
\hline & NS1209 & \begin{tabular}{|l|} 
CNRYSLER IMPERIAL \\
$\$ 2.50$ ea.; 3 for $\$ 6.60$ \\
\end{tabular} & & & NSI221 & $\begin{array}{l}\text { CoLDTLocks } \\
\$ 1.75 \text { ea.; } 3 \text { for } \$ 4.65 \\
\end{array}$ & & & HSBASO & $\begin{array}{l}\text { PIXIE NEOGE } \$ 3.50 ; 12 \text { for } \$ 12.50 \\
\$ 1.25 \text { ea.; } 3 \text { for } \$ 3.50\end{array}$ & \\
\hline & NSO217 & $\begin{array}{l}\text { FORTYNINER } \\
\$ 2.25 \text { Ea.; } 3 \text { for } \$ 6.00\end{array}$ & & & HSO220 & $\begin{array}{l}\text { IIIMINY CRICKET } \\
\$ 2.00 \\
\end{array}$ & & & NSBAS1 & $\begin{array}{l}\text { IACKIE } \\
\$ 2.00 \text { ea.; } 3 \text { for } \$ 5.25: 12 \text { for } \$ 20.00\end{array}$ & \\
\hline & \begin{tabular}{l|l} 
AS1224 \\
\end{tabular} & $\begin{array}{l}\text { MELEN TRAUBEL } \\
\$ 2.75 \text { ea.; } 3 \text { for } \$ 7.20\end{array}$ & & & $\begin{array}{ll}\text { MSO220 } \\
\end{array}$ & $\begin{array}{l}\text { LILIBET } \\
\$ 2.00 \text { ea.: } 3 \text { for } \$ 5.25\end{array}$ & & & MS84S2 & $\begin{array}{l}\text { CLIMBING PINK CAMEO } \\
\$ 2.25 \text { ea.; } 3 \text { for } \$ 5.75 ; 12 \text { for } \$ 22.50\end{array}$ & \\
\hline & \begin{tabular}{l|l} 
HS1220 \\
\end{tabular} & $\begin{array}{l}\text { LAS VEGAS } \\
\$ 2.50 \mathrm{ea.;} ; 3 \text { for } \$ 6.60\end{array}$ & & & NS1230 & $\begin{array}{l}\text { MARGO KOSTER } \\
\$ 1.50 \text { ea.; } 3 \text { for } \$ 3.90\end{array}$ & & & NSBA53 & \begin{tabular}{|l|l} 
REO IMP \\
$S 1.25$ eq.; 3 for $\$ 3.50 ; 12$ for $\$ 12.50$
\end{tabular} & \\
\hline & NS1231 & $\begin{array}{l}\text { MARK SULLIIVAN } \\
\$ 1.75 \text { ea.; } 3 \text { for } \$ 4.65\end{array}$ & & & NS1233 & $\begin{array}{l}\text { MEXICALI ROSE } \\
\$ 2.50 \text { ed.: } 3 \text { for } \$ 6.60\end{array}$ & & & NS6454 & \begin{tabular}{|l} 
PIIK Dor \\
S1.25 ea.; 3 for $\$ 3.50 ; 12$ for $\$ 12.50$
\end{tabular} & \\
\hline & NS1232 & $\begin{array}{l}\text { MERAY WIDOW } \\
\$ 2.75 \text { ea.; } 3 \text { for } \$ 7.20\end{array}$ & & & NS1241 & $\begin{array}{l}\text { PIMOCCNIO } \\
\$ 1.75 \text { ea.; } 3 \text { for } \$ 4.65\end{array}$ & & & NSWSI & $\begin{array}{l}\text { OAKINGGON RUBY } \\
\$ 1.25 \text { ea,; } 3 \text { for } \$ 3.50 ; 12 \text { for } \$ 12.50\end{array}$ & \\
\hline & MS10234 & $\begin{array}{l}\text { MISSION GELLS } \\
\text { \$2.00 ea.; } 3 \text { for } \$ 5.25\end{array}$ & & & NSO24S & $\begin{array}{l}\text { REO PINOCCNIO } \\
51.75 \text { ea.; } 3 \text { for } \$ 4.65\end{array}$ & & & NSOA60 & $\begin{array}{l}\text { PATTY LOU } \\
\$ 1.25 \text { ea.; } 3 \text { for } \$ 3.50 ; 12 \text { for } \$ 12.50\end{array}$ & \\
\hline & MS1235 & \begin{tabular}{|l|} 
MILNT \\
S1. 50 ea.; 3 for $\$ 3.90$ \\
\end{tabular} & & & NS1252 & $\begin{array}{l}\text { SPARTAN } \\
\text { \$2.75 ea.; } 3 \text { for } \$ 7.20 \\
\end{array}$ & & & NSW662 & $\begin{array}{l}\text { CENTENAILL MISS } \\
\$ 1.25 \text { ea.; } 3 \text { for } \$ 3.50 ; 12 \text { for } \$ 12.50\end{array}$ & \\
\hline & & TOTAL & & & & & & & & TOTAL & \\
\hline
\end{tabular}




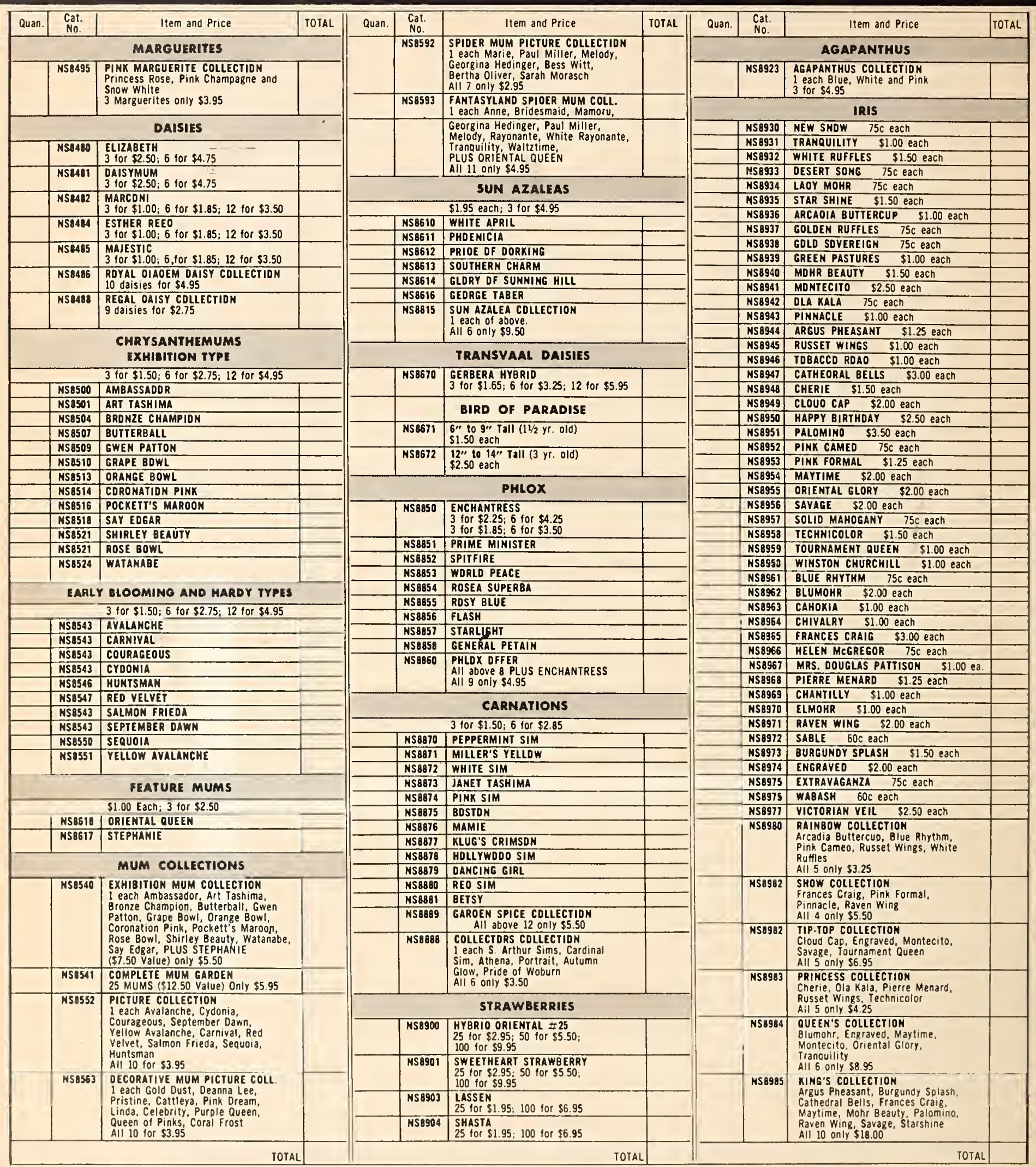


 \\ D BULBS, SEEDS \& ACCESSORIES ORDER FORM}

CUSTOMER SERVICE-Usually onother variety of same color and quolity will be sent shauld we be aut af one yau order. If you da not wish this serv. ice mork " $X$ " in bax at right.

NAME.

Please Print ar Type

ADDRESS

CITY

ZONE

STATE

$\square$ If you have moved since your last order please indicate former city.

$\square$ If merchandise is to be sent to another address please fill in name and complete address.

NAME

ADDRESS

STATE

CITY___ STATE

\begin{tabular}{|c|c|c|c|}
\hline Quan. & $\begin{array}{l}\text { Cat. } \\
\text { No. }\end{array}$ & Item and Price & TOTAL \\
\hline \multicolumn{4}{|c|}{ BULBS } \\
\hline & 5005 & $\begin{array}{l}\text { GIANT AMARYLLIS } \\
3 \text { for } \$ 1.39 ; 6 \text { for } \$ 2.69\end{array}$ & \\
\hline & 5025 & $\begin{array}{l}\text { ANEMONES, GT. FRENCH, LGE. BULBS } \\
12 \text { for } 79 c_{;} 24 \text { for } \$ 1.49 ; \\
48 \text { for } \$ 2.85 ; 96 \text { for } \$ 5.55\end{array}$ & \\
\hline & 5030 & $\begin{array}{l}\text { ANEMONES, BEODING SIZE } \\
50 \text { for } \$ 1.00\end{array}$ & \\
\hline & 5040 & $\begin{array}{l}\text { RANUNCULUS, JUMBO MIXEO } \\
12 \text { for } \$ 1.55 ; 24 \text { for } \$ 2.95 ; \\
48 \text { for } \$ 5.75 ; 96 \text { for } \$ 11.25\end{array}$ & \\
\hline & 5040 & $\begin{array}{l}\text { RANUNCULUS, EX. IGE. MIXED } \\
12 \text { for } 98 c_{;} 24 \text { for } \$ 1.85 ; \\
48 \text { for } \$ 3.60 ; 96 \text { for } \$ 7.10\end{array}$ & \\
\hline & 5042 & $\begin{array}{l}\text { RANUNCULUS, BEDOING SIZE } \\
25 \text { for } \$ 1.00\end{array}$ & \\
\hline & 5051 & $\begin{array}{l}\text { RANUNCULUS-BULK } \\
1 / 4 \mathrm{lb} \$ 6.75\end{array}$ & \\
\hline & 5055 & $\begin{array}{l}\text { COMBIN ATION OFFER } \\
25 \text { Ranunculus, } 50 \text { Anemones } \\
75 \text { Bulbs } \$ 1.89\end{array}$ & \\
\hline & 5075 & $\begin{array}{l}\text { BE GONIAS, OBL. RUFFLEO CAMELLIA } \\
5 \text { for } \$ 1.95 ; 10 \text { for } \$ 3.65\end{array}$ & \\
\hline & 5080 & $\begin{array}{l}\text { BE GONIAS, DOUBLE PICOTEE } \\
5 \text { for } \$ 1.95 ; 10 \text { for } \$ 3.65\end{array}$ & \\
\hline & 5081 & $\begin{array}{l}\text { GERMAIN'S SELECT BEGONIA OFFER } \\
3 \text { for } \$ 1.85 ; 6 \text { for } \$ 3.45\end{array}$ & \\
\hline & 5082 & $\begin{array}{l}\text { GERMAIN'S SELECT NANGING } \\
\text { BASKET BEGONIA } \\
3 \text { for } \$ 1.85 ; 6 \text { for } \$ 3.45 \\
\end{array}$ & \\
\hline & 5085 & $\begin{array}{l}\text { BEGONIAS, NAKGING BASKET } \\
3 \text { for } \$ 1.35 ; 6 \text { for } \$ 2.50\end{array}$ & \\
\hline & 5093 & $\begin{array}{l}\text { BEGONIA PICTURE COLLECTION } \\
5 \text { for } \$ 2.35 ; 10 \text { for } \$ 4.50\end{array}$ & \\
\hline & 5100 & $\begin{array}{l}\text { BEGONIA BARGAIN OFFER } \\
4 \text { for } \$ 1.00\end{array}$ & \\
\hline & 5145 & $\begin{array}{l}\text { CALLA LILY, PINK } \\
3 \text { for } \$ 1.00\end{array}$ & \\
\hline & 5147 & $\begin{array}{l}\text { CALLA LILY, GOLOEN EX. LGE. } \\
1 \text { for } \$ 1.00 ; 3 \text { for } \$ 2.50\end{array}$ & \\
\hline & $51 \overline{48}$ & $\begin{array}{l}\text { CALLA LILY, GOLOEN YELLDW } \\
3 \text { for } \$ 1.00\end{array}$ & \\
\hline & 5170 & $\begin{array}{l}\text { FANCY LEAF CALAOIUMS } \\
5 \text { for } \$ 2.35 ; 10 \text { for } \$ 4.50\end{array}$ & \\
\hline & 5173 & $\begin{array}{l}\text { CALAOIUM, BARGAIN OFFER, } \\
\text { NUGE BULB } \\
1 \text { for } \$ 1.25 ; 3 \text { for } \$ 3.25\end{array}$ & \\
\hline & 5180 & $\begin{array}{l}\text { CALADIUM, BEDOING SIZE } \\
3 \text { for } \$ 1.00\end{array}$ & \\
\hline & 5273 & $\begin{array}{l}\text { GLADIOLUS CDLLECTION, } \\
\text { NEAT TREATED } \\
12 \text { for } \$ 1.45 ; 24 \text { for } \$ 2.65\end{array}$ & \\
\hline & 5278 & $\begin{array}{l}\text { GLAOIOLUS, BARGAIN COLLECTIDN } \\
15 \text { for } \$ 1.00 ; 30 \text { for } \$ 1.89 \\
45 \text { for } \$ 2.75 ; 60 \text { for } \$ 3.65\end{array}$ & \\
\hline & 5279 & $\begin{array}{l}\text { GLAOIOLUS, TIP-TDP COLLECTIDN } \\
25 \text { for } \$ 2.25 ; 50 \text { for } \$ 4.25 ; \\
100 \text { for } \$ 7.95\end{array}$ & \\
\hline & 5285 & $\begin{array}{l}\text { MINIATURE GLADIOLUS } \\
10 \text { for } \$ 1.95\end{array}$ & \\
\hline & 5298 & $\begin{array}{l}\text { GLOXINIA } \\
5 \text { for } \$ 2.25 ; 10 \text { for } \$ 4.25 \\
\end{array}$ & \\
\hline . & 5580 & $\begin{array}{l}\text { DANLIA, SPECIAL DFFER DECDRATIVE } \\
3 \text { for } \$ 1.00\end{array}$ & \\
\hline & 5581 & $\begin{array}{l}\text { DANLIA, BARGAIN DFFER PDMPDN } \\
3 \text { for } \$ 1.00\end{array}$ & \\
\hline
\end{tabular}

\begin{tabular}{|l|l} 
Quan. & $\begin{array}{l}\text { Cat } \\
\text { No. }\end{array}$ \\
\hline
\end{tabular}

Quan. No.

\begin{tabular}{l|l}
\hline & 5 \\
\hline & 5 \\
\hline & 5 \\
\hline & 5 \\
\hline & 5 \\
\hline & 5 \\
\hline & 5 \\
\hline & 559 \\
\hline & 5 \\
\hline & 5 \\
\hline & 5 \\
\hline & 5 \\
\end{tabular}

\section{AMOUNT ENCLOSED \\ $\$$ \\ $\square$ Check $\square$ Money Order \\ Calif. customers pleas
add $\mathbf{4 \%}$ Sales Tax}

NON-WARRANTY. Germain's Inc. gives no warranty, express or implied as to the praductiveness af seeds, bulbs or plonts it sells ond will nat be in ony woy respansible for the crop. Our liability in all instances is limited to the purchase price of the seed, bulbs, or plonts.

TERMS: Send remittance in full with your arder. We pre-pay pastoge. WE DO NOT SHIP C.O.D.

DO NOT WRITE IN SPACE BELOW

\begin{tabular}{|c|l|l|l|l|l|}
\hline Item and Price & TOTAL & Quan. & $\begin{array}{c}\text { Cat. } \\
\text { No. }\end{array}$ & Item ano Price & TOTAL \\
\hline
\end{tabular}

\section{BULBS}

DAHLIA, BARGAIN OFFER CACTUS

5503 OAHLIA, COLLECTION "A"

6 for $\$ 4.65$

DAHLIA, COLLECTION" $B$

6 for $\$ 3.95$

5586 OANLIA, COLLECTIONS "A" AKD "B"

12 for $\$ 8.00$

5587 DAHLIA, POMPON COLLECTION

10 for $\$ 3.95$

5589 DAHLIA, CACTUS, CUTTING SIZE

5 for $\$ 3.95$

5591 OANLIA, CACTUS, KING SIZE

5 for $\$ 4.25$

5593 OANLIA, CACTUS COLLECTION

10 for $\$ 8.00$

5615 OANLIA, SPECIAL CUTTING

5 for $\$ 2.50$

5779 TIGRIOIA (TIGER FLOWER)

12 for $\$ 1.00$

5792 TUBEROSE, DOUBLE PEARL

8 for $\$ 1.00$

5815 SPREKELIA FORMOSISSIMA

3 for $\$ 2.25 ; 6$ for $\$ 4.00$

\section{FLOWER SEEDS}

2040AK ALYSSUM, KOLORCOAT

Mixture of Royal Carpet \&

Carpet of Snow

2045 ALYSSUM, CARPET OF SNOW

Pkt. $15 \mathrm{C}$

2048 ALYSSUM, ROYAL CARPET

Pkt. 25C

2240 ASTER, CALIFDRNIA GIANTS

Pkt. $25 \mathrm{C}$

2631 BATCHELOR BUTTON

Pkt. $25 \mathrm{C}$

2759 COSMOS, MANDARIK

50c Pkt.

COSMOS, SENSATIION

$15 \mathrm{C}$ Pkt.

2924 CALIFDRNIA POPPY (ESCNSCHDLTZIA)

Pkt. $15 \mathrm{C}$

GDMPNRENA, BUDDY

Pkt. $\$ 1.00$

3035 GOMPHRENA, CISSY

Pkt. $\$ 1.00$

3035A CDMBINATIDN DFFER

1 Pkt. Each CISSY AND BU0or

Both for $\$ 1.60$

3201 MORNING GLORY, HEAVENLY BLUE

Pkt. $15 \mathrm{C}$

3233 LARKSPUR, GIANT IMPERIA

PARKSPU

3365K MARIGDLO, CRACXERJACK

Pkt. 25c

3392 BELLS OF IRELANO

Pkt. 25c

3430 RASTURTIUM

\section{FLOWER SEEDS}

3595K PETUNIA, REO SATIN, F1 HYBRIO

3597K PETUMIA, PEACH SATIN, F1 NYBRID

Pkt $50 \mathrm{C}$

3603K PETUNIA, PINK SATIN, F1 HYBRIO

4010 VERBENA, HYBRIOA, CHOICE MIXEO

Pkt. $15 \mathrm{c}$

1104 ZINMIA, ORTHO POLXA

\begin{tabular}{l} 
Pkt. 25C \\
\hline 150 ZINNIA, LILLIPUT
\end{tabular}

4279 SWEET PEAS EARLY

FLOWERING MIXEO

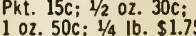

4419 SWEET PEAS, CUTNBERTSON MIXED Pkt. $15 \mathrm{c} ; 1 / 202.25 \mathrm{c}$;

1 $02.45 c_{;} 1 / 4 \mathrm{lb}$. $\$ 1.40$

4419K SWEET PEAS, XOLORCOAT

(CUTHBERTSON)

Large $6 \times 9$ Pkt. $50 c$

C502 GERMAIN'S BRAKD MERION

XENTUCKY BLUEGRASS

$1 / 2 \mathrm{lb}$. carton $\$ 2.30$
1 Ib. carton $\$ 4.10$

C512 GERMAIN'S BRANO WHITE CLOVER

$1 / 2$ |b. 90C; 1 Ib. $\$ 1.70$

C500 "12" BRANO LAWN SEED

$1 \mathrm{lb}$. carton $\$ 1.80 ; 5 \mathrm{lb}$. carton

$\$ 7.85 ; 25$ Ibs. $\$ 35.00$

C504 KOLORCOAT OICNDNORA

Jumbo $6 \times 9$ Pkg. $\$ 1.00 ; 1$ lb. $\$ 2.85$

GERMAIN'S BEAUTILAWH

BRAND OICNONORA

4 02. Shaker-ToD $\$ 1.45$

C510 DICKDMDRA \& CLOVER

\section{GARDEN ACCESSORIES}

\begin{tabular}{|c|c|}
\hline$E 612$ & $\begin{array}{l}\text { TWIST-EMS } \\
1 \text { Pkg. } 2008=60 \mathrm{C}\end{array}$ \\
\hline E613 & $\begin{array}{l}\text { TWIST-EMS } \\
1 \text { Pkg. } 10016 " 60 \mathrm{C}\end{array}$ \\
\hline E6 14 & $\begin{array}{l}\text { TWIST-EMS } \\
1250 \mathrm{ft} \text {. Roll } \$ 1.25\end{array}$ \\
\hline$E 603$ & $\begin{array}{l}\text { FLYING OISK } \\
50 \text { for } \$ 2.00\end{array}$ \\
\hline E604 & $\begin{array}{l}\text { TRAIK-ETTS } \\
60^{\prime \prime} \times 72^{\prime \prime} 90 \mathrm{C} \text { each }\end{array}$ \\
\hline E605 & $\begin{array}{l}\text { TRAIN-ETTS } \\
60^{\prime \prime} \times 96 " \$ 1.15 \text { each }\end{array}$ \\
\hline E606 & $\begin{array}{l}\text { TRAIN-ETTS } \\
60^{\prime \prime} \times 180^{\prime \prime} \$ 1.60 \text { each }\end{array}$ \\
\hline$\overline{E 621}$ & $\begin{array}{l}\text { WAYWARO VINE GUIOES } \\
1 \text { Pkg. of } 25 \$ 1.15\end{array}$ \\
\hline
\end{tabular}

3720 PORTULACA, DOUBLE MIXEO

4129 ZINNIA, LUCKY STRIKE

\section{LAWN SEED}

$1 \mathrm{lb}$. carton $\$ 4.95$ 
Medium size bulbs, but larger than the bulbs used by commercial cut flower growers in Southern California. Beautiful flowers from every bulb. This is our FAMOUS "\$" SPECIAL in Gladiolus.

NO. 5278-15 BULBS ONLY $\$ 1.00$

Tiger-Flower (Tigridia)

SENSATIONAL GARDEN FLOWER-EASY TO GROW

One of the most rewarding plants we know-yet few people are familiar with this flower. Beautiful colors with chartreuse spotted center cup. Plant in sunny location and grow like gladiolus, but remember, they are hardier than gladiolus in cold areas. For spectacular garden effect, plant in clumps of about 6 bulbs in a $6^{\prime \prime}$ circle.

Beautiful blend of mixed colors.

NO. 5779-12 BULBS

ONLY \$1.00

\section{Ranunculus}

Best Bulb bargain ever offered. These bedding size Ranunculus bulbs will produce a mass of colorful cut flowers that will highlight your whole garden.

NO. 5042-25 BULBS ONLY $\$ 1.00$

\section{Anemones}

These bargain bedding size bulbs will produce an abundance of 3 to 4 inch flowers in exciting colors the very first year. NO. 5030-50 BULBS ONLY \$1.00

Giant IRanunculus and

Anemones

The perfect combination for cut flowers and garden show

NO. 5055-COMBINATION OFFER

(25 Ranunculus and 50 Anemones)

75 BULBS

ONLY $\$ 1.89$

Cactus Dahlia

THREE SEPARATE VARIETIES IN BEAUTIFUL COLORS NO. 5582

3 CACTUS DAHLIA TUBERS

$\$ 1.00$

\section{Pompon Dahlia}

EACH ONE DIFFERENT. CUT FLOWERS GALORE!

NO. 5581-3 DAHLIA TÚBERS $\$ 1.00$

\section{Giant Dahlias}

THREE DIFFERENT GARDEN GIANTS IN GORGEOUS SHADES

NO. 5580
3 GIANT DAHLIA TUBERS

$\$ 1.00$

Fancy Leaf Caladiums

BEDDING SIZE BULBS

NO. 5180-3 BULBS

ONLY $\$ 1.00$

\section{Begonia Bargain Offer}

Sure to produce exceptionally fine flowers for your Begonia garden. These will grow larger each year and for several years. 4 Beautiful Camellia Flowered Begonias. We choose the colors.

\section{NO. 5100}

ALL 4 TUBERS ONLY $\$ 1.00$

\section{Calla Lilies}

GOLDEN YELLOW

Grand, deep yellow flowers on tall stems. Leaves are spotted white.

NO. 5148-3 BULBS

ONLY $\$ 1.00$

\section{Calla Lilies}

RARE PINK

Exceptionally lovely calla produces dainty carmine rose flowers about $2^{\prime \prime}$ in diameter.

NO. 5145-3 BULBS ONLY $\$ 1.00$

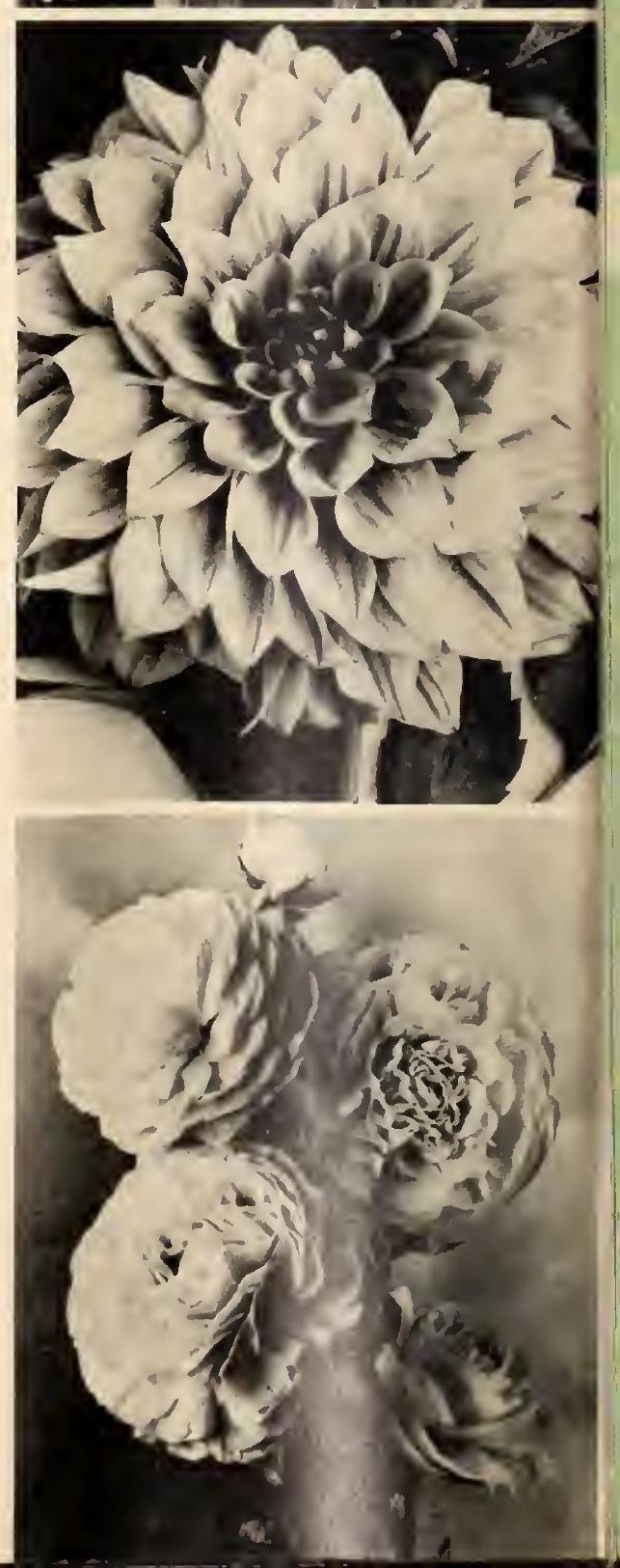




\section{Merry, Merry ... AND KOLORCOAT ALL IN A ROW}

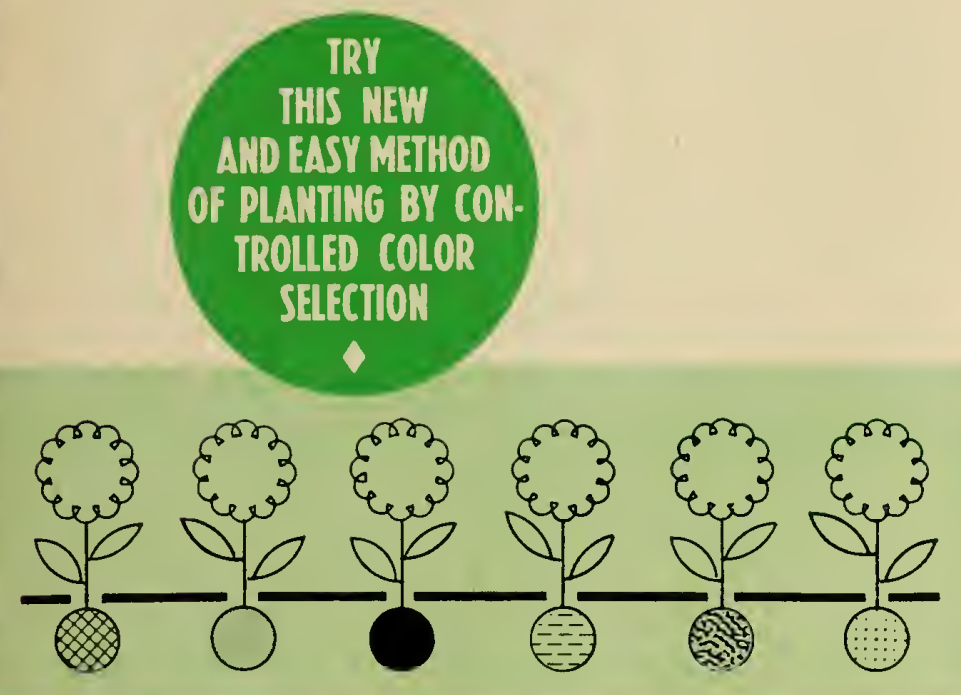

Flower gardening has been revolutionized-made easier-more fun-more sure.

The reason is KOLORCOAT, an exclusive process of seed coating developed through extensive experimentation in the Germain's laboratory.

As a pioneer California company, Germain's has always led the industry in developing new and improved flower seeds.

Carefully selected and processed through our modern laboratory and facilities, Kolorcoat seed is the gardener's best friend.

With this exclusive Germain's process each seed is individually color-coated so that the gardener knows in advance the actual, true shade of the flower itself. KOLORCOATING takes the guesswork out of planting.

\section{HOME GARDEN SPECIALTIES}

\section{FLYITE DIRS}

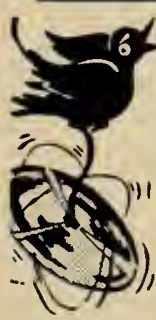

\section{SCARE Birds and} Amazing protection for newi planted seeds, berries, tender seedings, fruit trees, etc. Made of shining aluminum, FLYING DISKS spin and whiri madly in all directions-give blinding reflections and weird fingling. cracking sounds - to scare birds and animais away. Easily strung across area to be protected - or from branches of fruit trees and vines.

E603-50 FLYING DISCS with complele instructions $\$ 2.00$

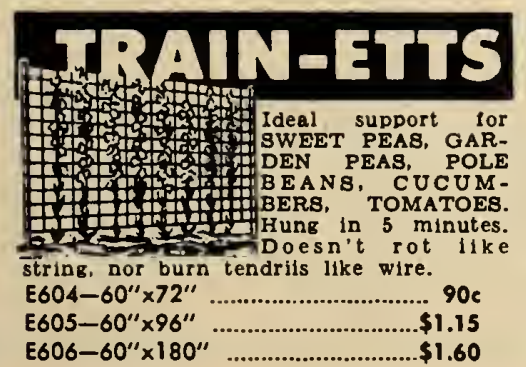

\section{Now! Have FINER Flowers and Vegetables}

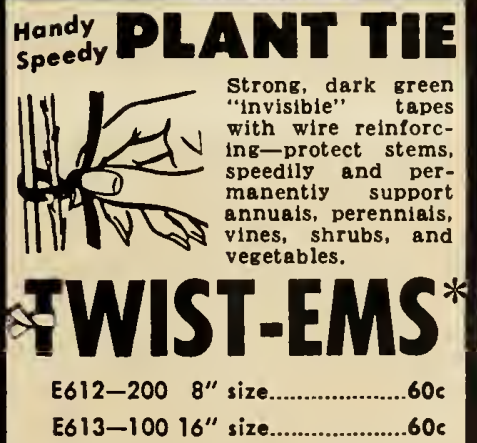

NEW! Have TWIST.EMS

ANY LENGTH YOU WISH HUNDREDS of uses around the garden or home. strong dark green "invisible" tape with wire reinforcing. Do the job

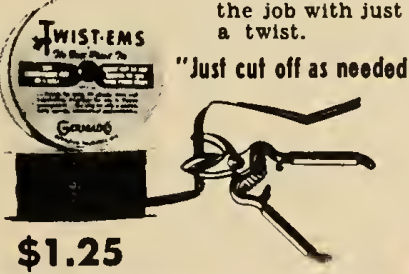

E614-CONTINUOUS ROLL OF TWIST-EM

\section{GERMAIN'S}

\section{APPROVED \\ GARDEN ACCESSORIES \\ TO MAKE YOUR GARDENING EASIER AND MORE FUN}

PRICES ON ALL ITEMS INCLUDE POSTAGE AND PACKING

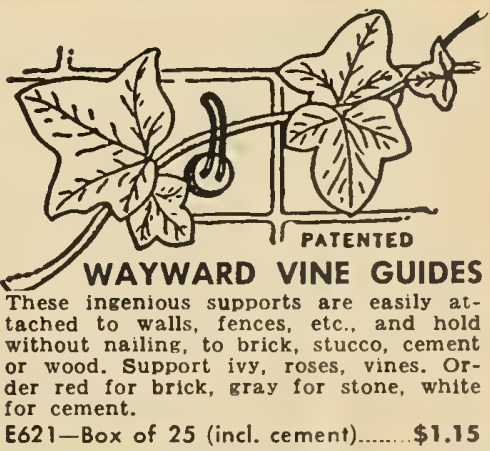




\section{A Big Surprise}

Buddy and Cissy

A RARE PAIR OF BORDER BEAUTIES BRINGS NEW GAIETY TO YOUR GARDEN. GLAMOROUS IN APPEARANCE! EASY TO GROW! BUDDY AND CISSY BRING A NEW LOOK TO YOUR BORDERS.

Recently in the Gomphrena (or Globe Amaranth) family a variety called "Buddy" was introduced which was very dwarf and compact, making an attractive garden plant. BUDDY has clover-like blooms of bright purple. This year's introduction, CISSY, has identical plants and blooms, except that they are pure, snowy white, growing only 6 inches tall, and with a full three months or more of blooms under any and all weather conditions. These little plants are wonderful subjects for a twin border or edging row. No special insect or disease problems, no fancy care-just lots of durable blooms and neat little plants; also an everlasting flower that can be used for making unusual winter bouquets. Watch the garden magazines pick this up!!

\section{AMERICA'S FAVORIIE FLOWERS}
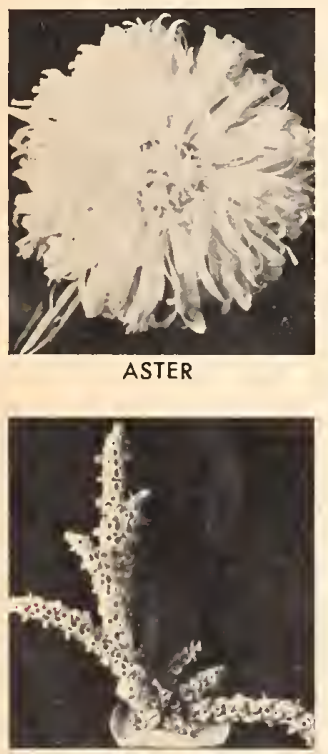

BELLS OF IRELAND
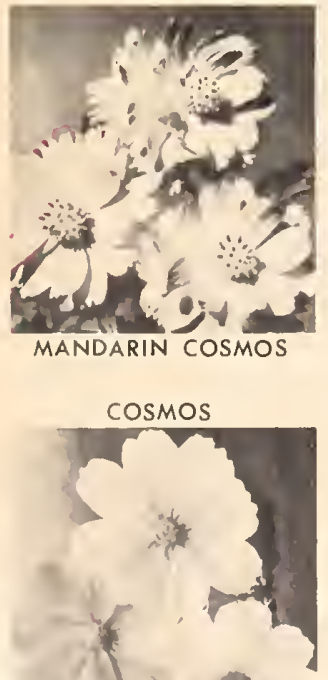

Alyssum-Carpet of Snow. The plants are flat and compact. Very dwarf. Spreads in carperNo. 2045 Pkt. 15c

Alyssum_Royal Carpet. An exceptional companion to Carpet of Snow. Rich velvet purple color. Is wonderfully effective in low border plant Na. 2048 Pkt. 25c

Aster-New Colifornia Giants Superfine Mixed. Chrysanthemum-like flowers, measure from five to six inches across. Blossoms full to the center
with broad curled and interlaced petals, borne on Na. 2240 Pkt. 25c

Bells of Ireland - Maucella Laevis is the botanical name of this skyracketing favarite. 2.4 inches tall. Bell shaped flowers. Both foliage and flowers are a pleasing apple green. Fine cut flower. Can be dried and used as an ever-
lasting.
Na. 3392 Pkt. 25c Bachelor Button-(Centaurea $C_{y}$ anus)-Red-White-Blue. The three favorite colors of this popular cut flower. Succeeding anywhere of this popular cut fower. Succeeding anywhere
and responding quickly to what little care and and responding quickly to what little care and
cultivation may be bestowed upon it. Dependable for summer and winter bouquets. 2631 Pkt. 25

Mandarin Cosmos_we are proud to introduce this year this strongly double, brilliant orange cosmos. Flowers frequently have 40 or more
petals, a real innovation in this class. but even more impressive are the Mandarin plants. The heavy, dense cover of foliage makes it superior to
any other variety. This pleasing foliage is mainany other variery. This pleasing foliage is main-
tained all through the season, even after the plants have been in bloom a long time, and converts cosmos from a sparse, open plant to a luxurious
garden specimen.

Cosmos-Sensotian Mixed. Easily grown from seed and succeeding anywhere. Flowers are extra large and will bloom fully two weeks before balanced mixture: Crimson, Pink, Radiance and
White.
No. 2773 Pkt. 15e California Poppy-(Eschschaltzia) Deep Orange. The Golden Poppy of California one of the favorite garden annuals throughout the

Larkspur-(Annual Delphinium)-Giont Imperiol Mixed. Larkspurs are one of the mose dependable of sources of cut flowers over a period and the colors are distinct and different from those
No. 3233 Pkt. 25e

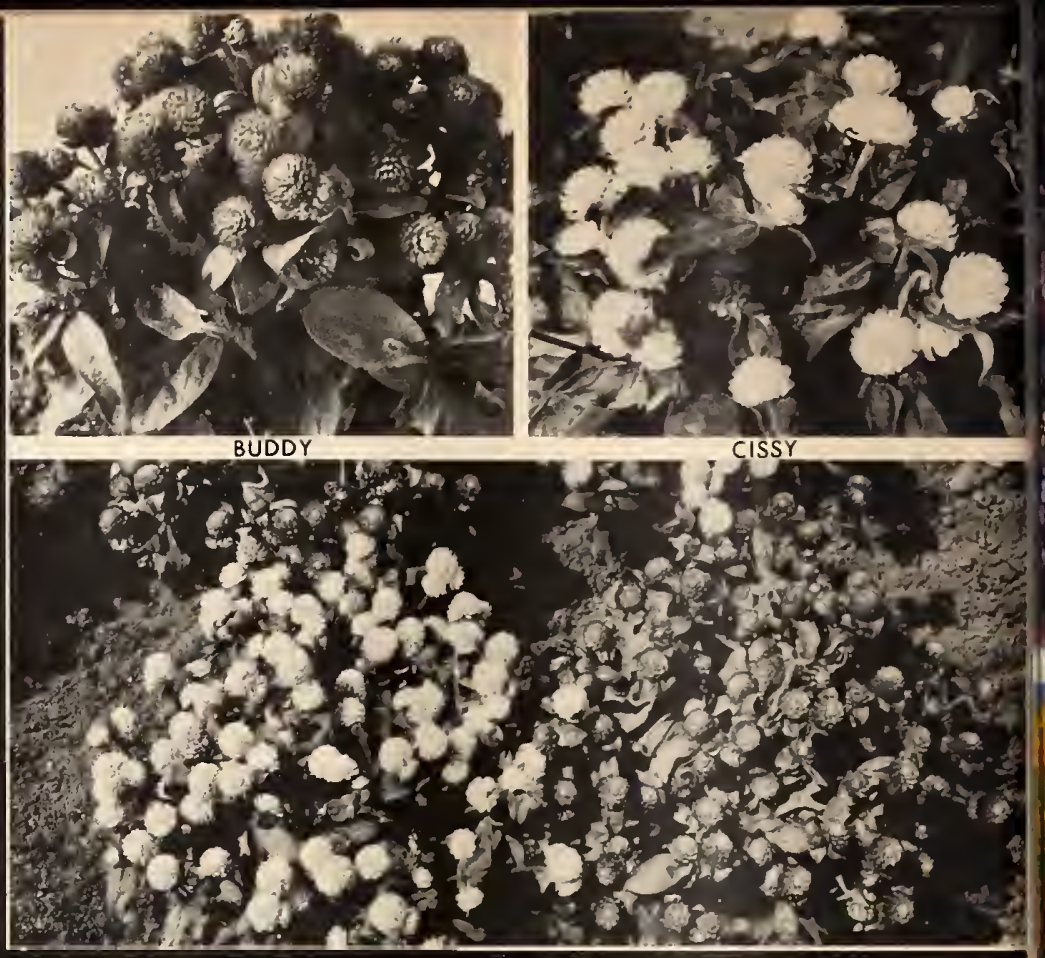

\section{GERMAIN'S HIGH QUALITY FLOWER SEEDS FOR SPECTACULAR EXHIBITION BLOOMS}

Morning Glory-(Ipamoea) - Clarke's Earliest Heavenly Blue. Annual Climber. Sky Blue. shading golden yellow in throat; extremely early.
Na. 3201 Pkt. $15 \mathrm{c}$

Nasturtium - Semi-Double Glariaus Gleam Hybrids Mixed. For color, length of bloom, ease of culture and general usefulness in the flower garden, the Nasturcium has no equal. The Gleam range of colors. Excellent for borders.
Na. 3430 Pkt. 15

Portulaca - Dauble Mixed. Sun loving, unequaled for summer color in low borders, beds and edgings. Brilliant ground cover. Flowers are
like little roses.
Na. 3720 Pkt. $15 c$ Sweet Peas - Early Flowering Mixed. A very wide range of colors are available in this group. Exira large, wavy petaled blossoms. Flowers are long stemmed and very fragrant. Early flowering variety bloom fully 3 weeks earlier than the regular No. 4279

Pkt. $15 c ; 1 / 2$ ax. 30c; 1 ax. 50c; $1 / 4$ lb. $\$ 1.75$

Sweet Peas - New Spring Flawering Cuthbertsan Mixed. Where spring planting is the rule and where early summer heat is a hazard, Curh Certsons are the newer, stronger varieries in this class. Na. 4419

Pk1. 15 c; $1 / 2$ ox. 25 ; 1 ax. $45 \mathrm{c} ; 1 / 4$ lb. $\$ 1.40$

Verbena-Hybrid, Choice Mixed. Effective perennial bedding plants. They require little atten in color and free blooming. Na.4010 Pkt. 15c Zinnia_Lilliput, Boby ar Pompon Mixed. The Lilliputs are among the most popular for cu flowers. Have a wide range of colors. Small flowers. very double. Zinnias are very easy to grow and very
showy.
Na. 4150 Pkł. 15 Zimnia-lucky strike. Newest color shades you have cver seen. Lucky Strike is acclaimed THE FIN flowers are on extra long stems. Vigorous plants grow 3 feet tall and bloom profusely the entire season. Ortho Polka Zinnia - Great, bi goily striped zinnias. More colorful and TWICE Polka comes i some solid colors, but mostly in combination whire and pink, rose and white, red and whise, lav ender and white, scarlet and yellow, orange and yel bicolors. Markings vary often on the same plant. from tiny dots to broad stripes and even to bloom different one. Na. 4104-Lorge $6 \times 9 \mathrm{pkg}$. $50 \mathrm{c} \mathrm{eo}$.

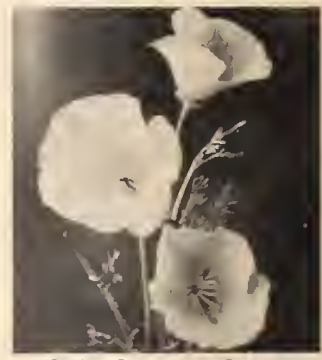

CALIFORNIA POPPY

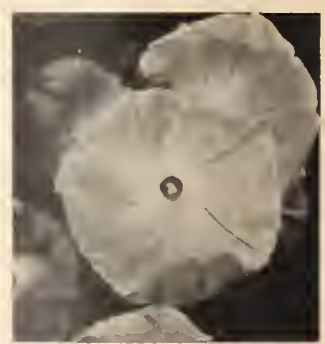

MORNING GLORY

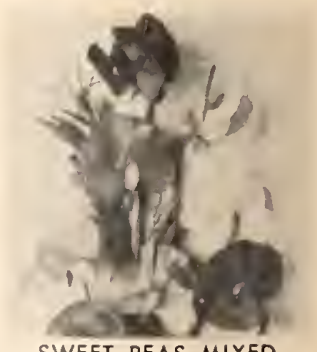

WEET PEAS MIXED

ORTHO POLKA ZINNIA

mityo lificer $77-7 x+3=5$

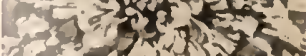

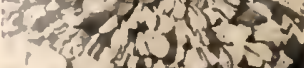
$x+10+5$ 


\section{Winiature}

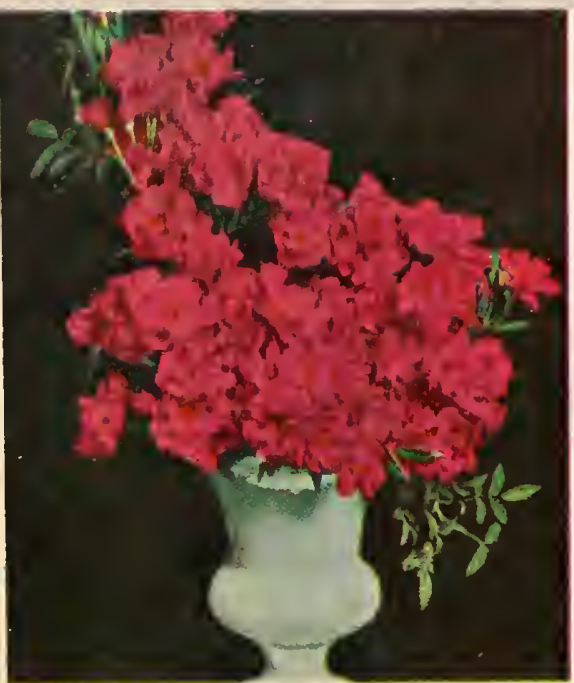

CL. MAGIC WAND

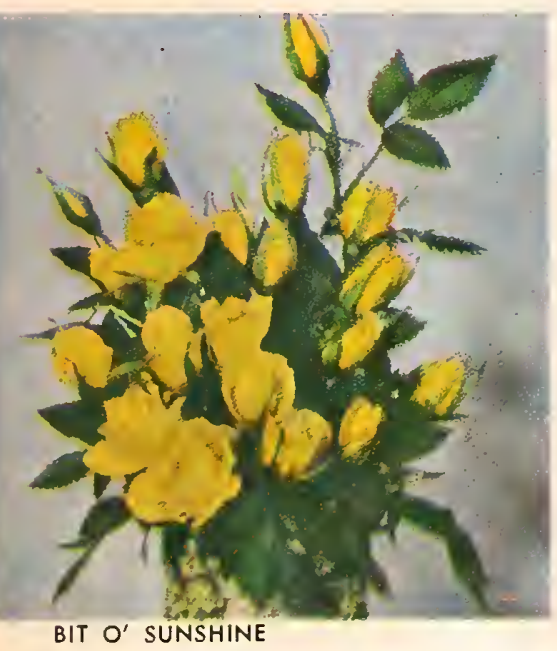

INTRODUCTORY COLLECTION 1 EACH DIAN-RED, JACKIE-YELLOW, FROSTY-WHITE.

NS8456 ALL 3 ONLY $\$ 5.00$ (\$6.00 VALUE)

SPECIAL OFFER $¥$

Any $3 \$ 1.25$ Miniature Rases PLUS Famous Jackie. (\$5.75 VALUE) NS8463

ALL 4 ONLY $\$ 4.95$

SPECIAL OFFER $\neq 2$

Any $3 \$ 1.25$ Miniature Roses PLUS the new DIAN. (\$5.75 VALUE) NS846S

ALL 4 ONLY $\$ 4.95$

FOR BORDERS OR PLANTER BOXES 12 PLANTS ANY ONE VARIETY (NO MIX. TURES) FOR THE PRICE OF 10.

$12 \$ 1.25$ Plants (same variety) $\$ 12.50$ $12 \$ 2.00$ Plants (same variety) $\$ 20.00$ $12 \$ 2.25$ Plants (same variety) $\$ 22.50$

\section{0.}

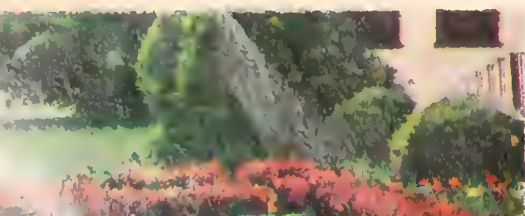

CLIMBING JACKIE (Pot. R.R.)

Soft yellow buds. Vigorous healthy plant. Here at last is your favorite "Jackie" in climbing form. Fragrant, everlooming.

$\$ 2.25$ EACH

3 FOR $\$ 5.75$

CIMIIING MAGIC WAND (Pat. R.R.) Brand new red ever-blooming miniature climber. Minute Tom Thumb buds, produced on tiny, glossy, fern-like foliage. Will climb up to 3-4 feet. Will even bloom in N58448

$\$ 2.25$ EACH

3 FOR $\$ 5.7 \mathrm{~S}$

CLIMBING PINK CAMEO (Pot. 1451) First truly Everblooming Miniature Rose Climbing Form. Perfect miniature rose-pink buds. Long lasting cut flowerswonderful boutonniere, corsage and 5 mall bouquet rose.
Shrub or small pillar (up to $5 \mathrm{feet}$ ). Will bloom first year. NS8452

$\$ 2.25$ EACH

3 FOR $\$ 5.7 \mathrm{~S}$

DIAN (Pat. RR) NEW 1958 INTRODUCTION

Brilliant soft red flowers with a glowing undertone. Fragrant, long lasting cut flowers. Excellent border or pot plant. Grows 12 to 14 inches high.

$\begin{array}{lll}\mathrm{N} 58443 & \$ 2.00 \text { EACH } & 3 \text { FOR } \$ 5.2 S\end{array}$

BIT D' SUNSIIINE (Pat. 1631)

Brightest yellow miniature. Shapely yellow buds in profusion on a bushy 12 -inch plant. Excellent pot plant.

$\begin{array}{lll}\text { NS8444 } & \$ 2.25 \text { EACH } & 3 \text { FOR } \$ 5.75\end{array}$

\section{JACKIE}

Compact sturdy plant to about 12 inches. Perfectly formed soft yellow buds. Very double, $11 / 4$ inch, fragrant flowers. Keep well as a cut flower. Color best in partial shade. Ideal pot plant as well as a border rose. N58451 $\$ 2.00$ EACH

3 FOR $\$ 5.25$

\section{LITTLE BUCKAROO (P.A.F.)}

Hardy, vigorous plant, will grow to 15 inches. Perfect border rose. Very lasting bright red flowers.

$\begin{array}{lll}\text { N58445 } & \$ 2.00 \text { EACH } & 3 \text { FOR } \$ 5.25\end{array}$

\section{FROSTY (Pot. 1412)}

One of the world's whitest roses. Glossy, disease free foliage on a nearly thornless plant. Excellent for pots, planter NS8447

$\$ 2.00$ EACH

3 FOR $\$ 5.25$

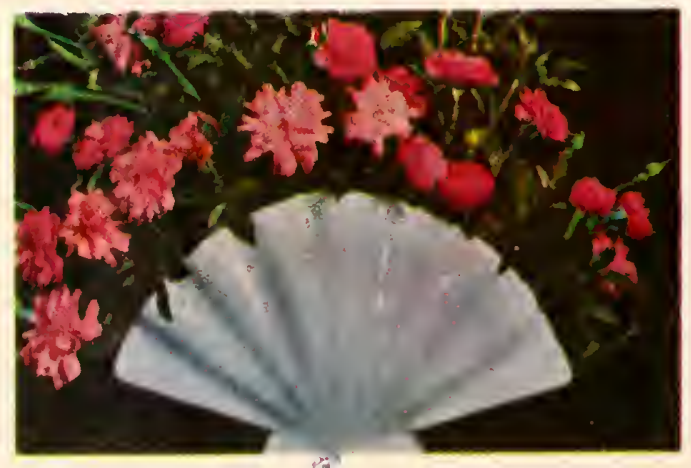

CLIMBING MINIATURE COLLECTIOH

CLIMBING MAGIC WAND, I CLIMEING JACKIE, I CLIMBING PINK CAMEO.

NS8457

ALL 3 FOR $\$ 5.75$

\section{○}

TOM THUMB MINIATURE ROSE COLLECTION

EACH PINK JOY, CENTENNIAL MISS, RED IMP, OAKINGTON RUBY, WHITE ASTER.

\section{N\$8459}

ALL 5 ONLY $\$ 5.75$
Tiny yet perfectly formed little hybrid tea type roses in Reds, Yellows, Pinks and White. Only 8 to 12 inches tall when full grown. Small bushes covered with blooms all season long make this unique variety a wonderful house plant as well as outdoor plant in window boxes, along walks, borders, etc. Just think what a marvelous gift these little fellows would make. Novel and unusual, they will be a welcome addition to any house or garden.

\section{ANY VARIETY LISTED BELOW \\ $\$ 1.25$ EACH 3 FOR $\$ 3.50$}

Pixie Hedge Rose (P.R.R.) NS8450

A compact miniature form of a multiflora hedge rose. Hundreds of delightful double soft pink tiny blooms about the size of a quarter. The everblooming plant has tiny glossy foliage and will grow to only 3 or 4 feet when fully mature. Perfect for lining
walks, hedge rows, along fence lines and many other different

\section{Mary Haywood (P.R.R.) NS8440}

Very double one-inch flowers. Bright pink from bud to fading flower. Makes a neat free-flowering plant about 10 inches high: abundant foliage. Excellent edging or pot plant.

Pink Joy (Pot. 1378) NS8454

Fragrant double pink flowers with beautifully shaped buds showing just a touch of salmon.

\section{Patty LoI (Pat. 1335) NS8460}

First bi-color. Blooms are rose with silver pink on reverse side of petals. Fully double and fragrant.

Centennial MisS (Pat. 1301) NS8462

Fragrant, fully double flowers. Rose red to deep wine red.

Red Ins (Pat. 1032) NS8453

Tiny, double bright red flowers. Blooms profusely.

\section{Oakington Ruby NS8458}

Miniature red buds open to double one-inch flowers. HardyMiniature red buds open to double one-inch flowers. Hardyall-around miniatures.

White Aster (Pat. R.R.) NS844)

First of a new type. Very bushy, compact plant covered with tiny soft pink buds which open into double one-inch white flowers. Numerous narrow petals give individual flowers the appearance of tiny crego aster blooms.

Cinderella (Pot. 1051) NS8442

Petite, double white blooms on a bushy vigorous plant.

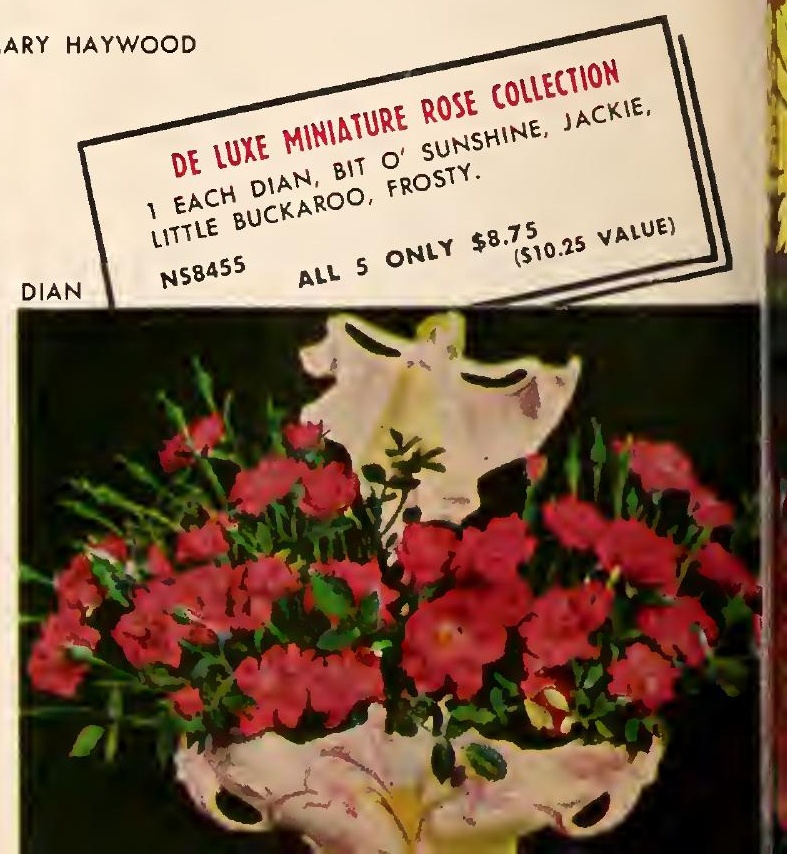




\section{TRANSVAAL DAISIES}

(GERBERA HYBRID)

Queen of the African flowers, these exotic, graceful Transvaal Daisies are a beauty blockbuster in any garden. Dynamic and different, the GIANT DUPLEX GERBERA will be the conversation piece of your garden.
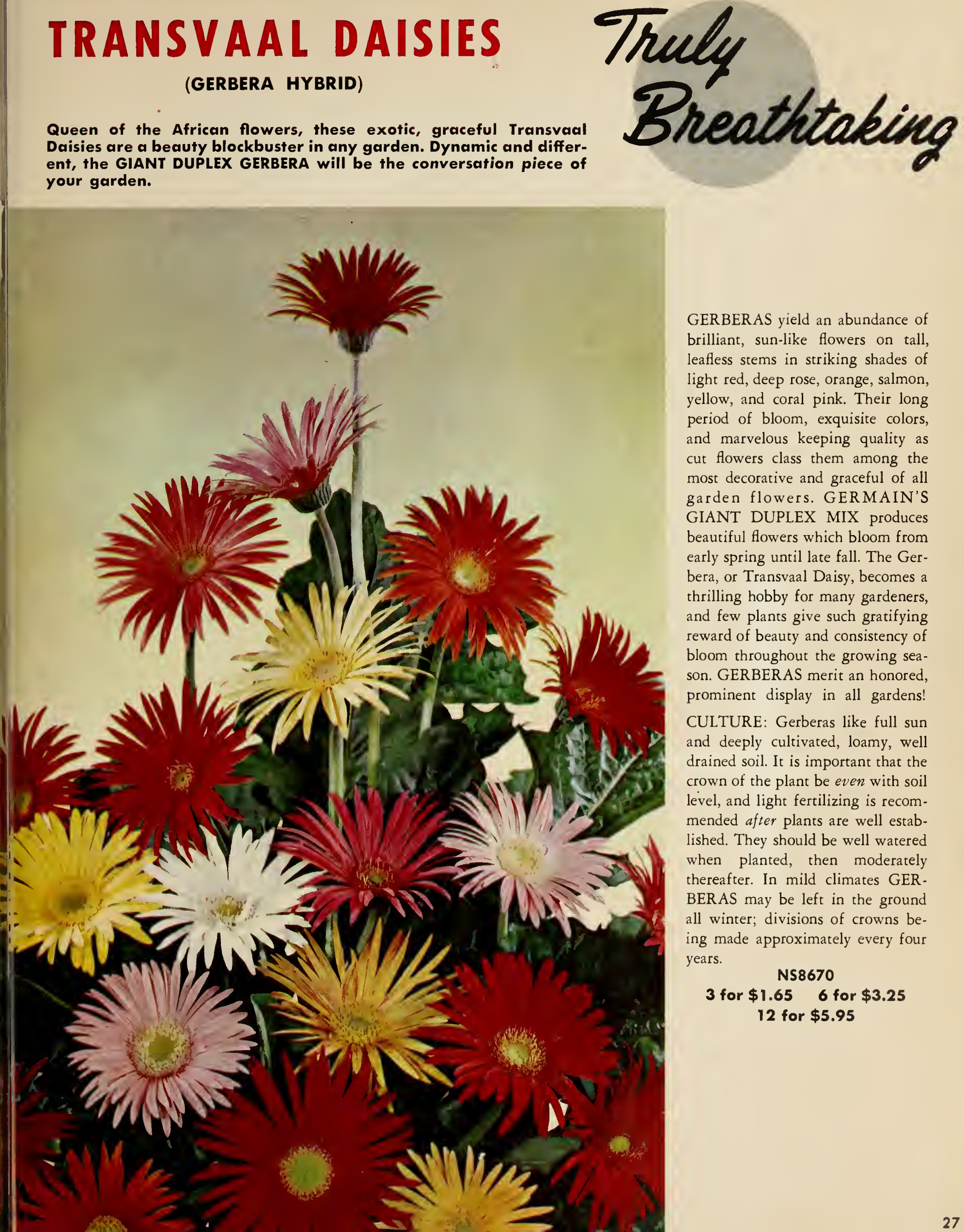

GERBERAS yield an abundance of brilliant, sun-like flowers on tall, leafless stems in striking shades of light red, deep rose, orange, salmon, yellow, and coral pink. Their long period of bloom, exquisite colors, and marvelous keeping quality as cut flowers class them among the most decorative and graceful of all garden flowers. GERMAIN'S GIANT DUPLEX MIX produces beautiful flowers which bloom from early spring until late fall. The Gerbera, or Transvaal Daisy, becomes a thrilling hobby for many gardeners, and few plants give such gratifying reward of beauty and consistency of bloom throughout the growing season. GERBERAS merit an honored, prominent display in all gardens! CULTURE: Gerberas like full sun and deeply cultivated, loamy, well drained soil. It is important that the crown of the plant be even with soil level, and light fertilizing is recom. mended after plants are well established. They should be well watered when planted, then moderately thereafter. In mild climates GERBERAS may be left in the ground all winter; divisions of crowns being made approximately every four years.

\section{NS8670}

3 for $\$ 1.65 \quad 6$ for $\$ 3.25$ 12 for $\$ 5.95$ 

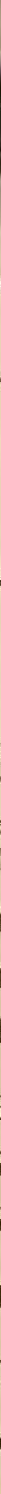

\section{EARLY BLOOMING HARDY MUMS}

\section{Sensational}

Gorgeous mums blooming in your garden weeks earlier than ever before. Famed the world over for the most striking brilliant show of color. The early blooming hardy varieties can be planted in massive displays, along driveways, or used for general garden planting. FILL YOUR GARDEN WITH COLOR THIS FALL.

\section{3 for $\$ 1.50 \quad 6$ for $\$ 2.75 \quad 12$ for $\$ 4.95$}

Avalanche-NS8542-Luscious ivory whire. Sept. 15.

Carnival-NS8543-Glorious blend of gold and bronze. Oct. 10th

Courageons-NS8544-Red decorative type. Oct. Sth.

Cydonia-NS8545-Vivid, fiery orange-red. Oct. 5th.

Huntsman-NS8546-Reddish bronze, lively and vivid. Oct. 5th

Red Velvet - NS8547-Smooth, soft, velvet red. Oct. 5 th.

Salmon Frieda-NS8548-Lovely salmon pink. Oct. 5th.

September Dawn-NS8549-Early clear pink. Sept. 15th

Sequoia-NS8550-Rich, mellow amber. Oct. 10th.

Yellow Avalanche-NS8551-Soft yellow. Decorative type. Sept. 15th

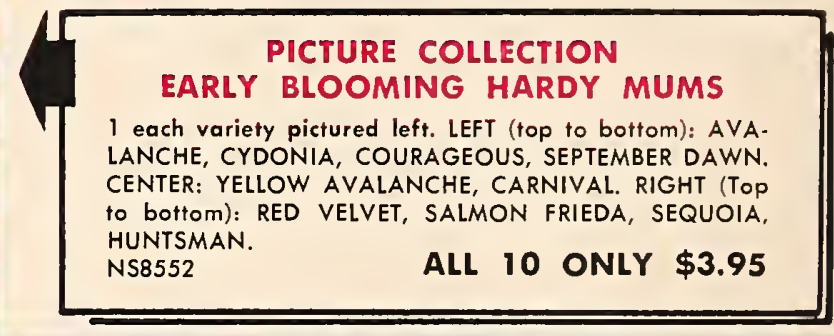

DECORATIVE MUM PICTURE COLLECTIOH Huge Flowers up to 4" Across in Exquisite clear colors. 1 eoch voriety pictured. LEFT (Top to Bottom): GOLD DUST - Cleor yellow, DEANNA LEE-Bright red, PRISTINEWhite, CATTLEYA-Orchid Pink. CENTER (Top to Bottom): PINK DREAM-True pink, LINDA-Rose Pink, CELEBRITYApricot-bronze. RIGHT (Top to Bottom): PURPLE QUEENDeep Purple, QUEEN OF PINKS-Orchid Pink, CORAL FROST-Bronze, coral ond pink. NS8563

ALL 10 ONLY $\$ 3.95$

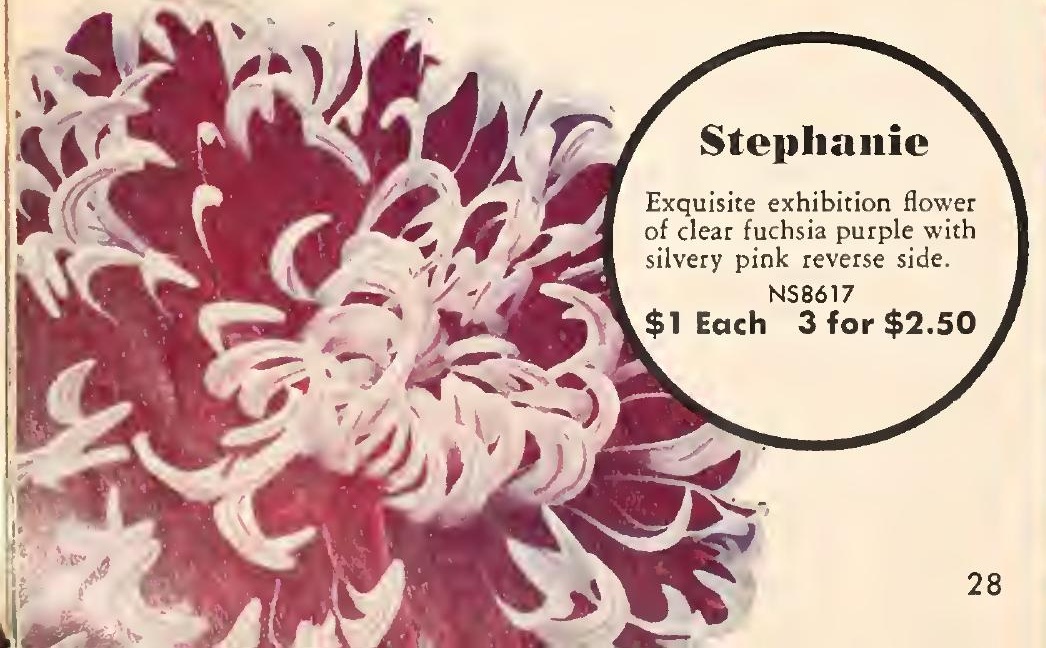

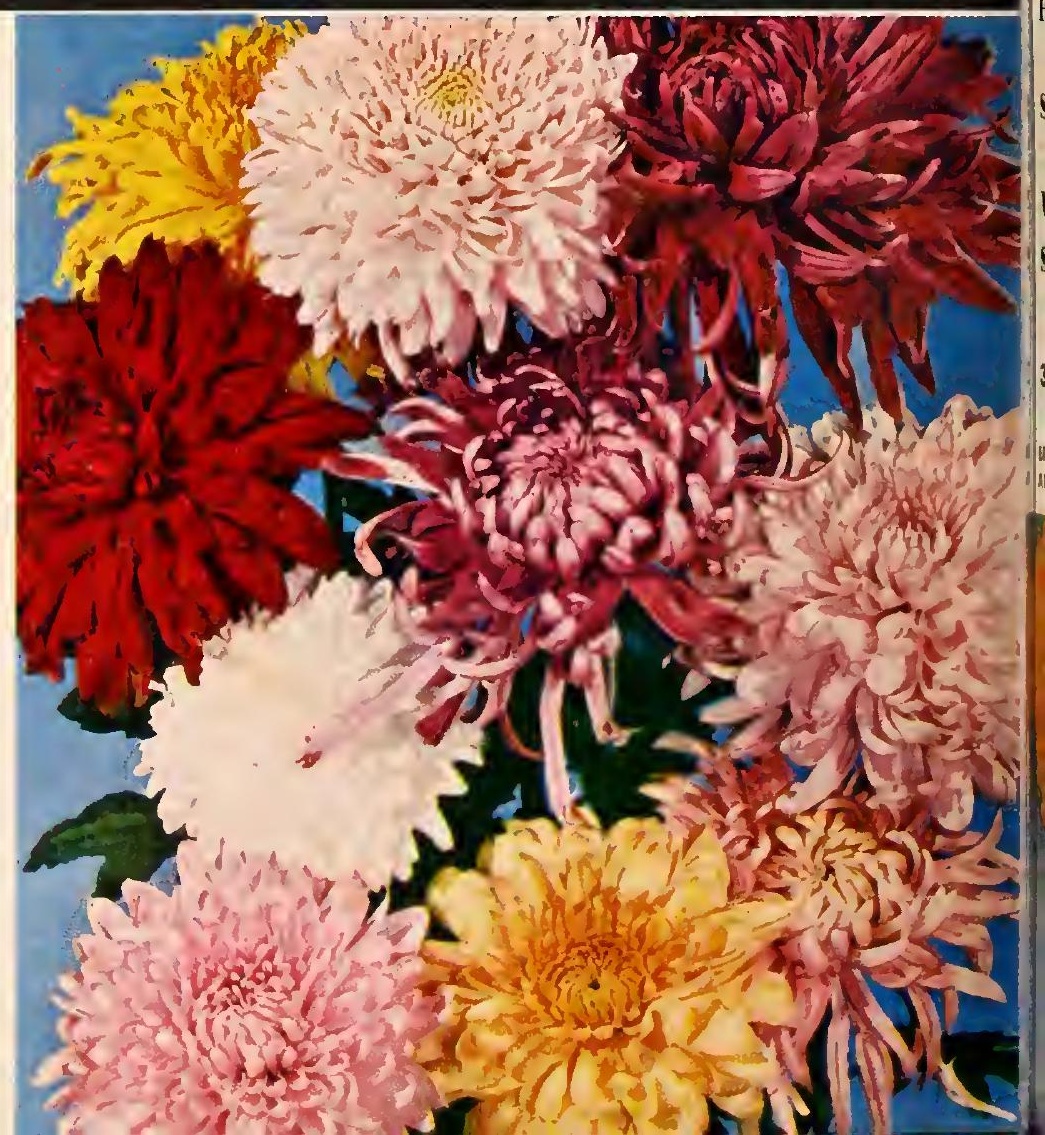




\section{ANTHEMUMS}

NOTE: We ship Rooted Cuttings from carefully selected disease-free parent stock. Praperly packed and ready to plant.

SHIPPING: We ship from mid-April thru June. In arder to insure safe arrival af yaur plants, we ship Air Parcel Pas where distances are great enaugh ta be benefited by this service.

FREE AIR PARCEL POST WITH ORDERS OVER \$5.00 Add $50 \mathrm{c}$ far arders less than $\$ 5.00$

CULTURE: Complete instructians far growing mums with each order. Approximate blaaming periad af each variety listed at end of description.

\section{SUPERB EXHIBITION MUMS}

These varieties develop into magnificent flowers 3 to $4^{\prime \prime}$ across and on some, 6 to $8^{\prime \prime}$ across. The most beautiful of all types of Mums. Giant, fully rounded blooms in gorgeous colors.

Ambassador-NS8500-Very large white incurved exhibiArt Tashima-NS8501-O One of the best laree yellows Bronze Champion_NS8504-Solid coppery bronze. Globular shape flowers supported by good

Butter Ball_NS8507-Clear lively yellow incurved. Giant Gwen Patton-NSB509-Most attractive globular flower Grape Bowl-NS8510-Very large incurved, exhibition cype. Deep purple at beginning, tad-

Orange Bowl-NS8513-The color is a most beautiful shade of warm bronze with an

Coromation Pink-NS8514-A true reflexed type exhibition flower in peerless shade of light rose. Oct, 20 th.

Pockett's Maroon-NS8516-Enthralling shade of velvety oxblood red with

I Rose Bowl_NS8522-Tremendously large incurved flowe in the giant exhibicion class. The color is a most pleasingly deep orchid pink, almost rose. Also has extra

Shirley Beauty-N\$8521-Deep maroon with buff reverse. Acclaimed by thousands during our show as one of the most outstanding recent introductions in this color. Lovely dark green foliage and medium height. Oct. $25 \mathrm{th}$ Watanabe-NS8524-Spectacular large incurved yellow. Say Edgar-NS8518-Rich wine red with silvery reverse.

ANY ABOVE EXHIBITION VARIETIES

3 for $\$ 1.50 \quad 6$ for $\$ 2.75 \quad 12$ for $\$ 4.95$

SRONZE CHAMPION (top left)

IRT TASHIMA (tOP right) SHIRLEY BEAUTY (bottam)

IMAGINE!

HUNDREDS OF

BLOOMS TO BRICHTEN

YOUR GARDEN IN THE FALL AFTER ALL OTHER FLOWERS HAVE FINISHED BLOOMING. A COMPLETE SELECTION

OF THE FINEST MUMS

6 AYAILABLE.
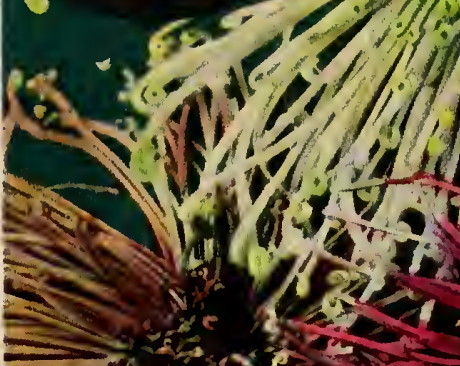

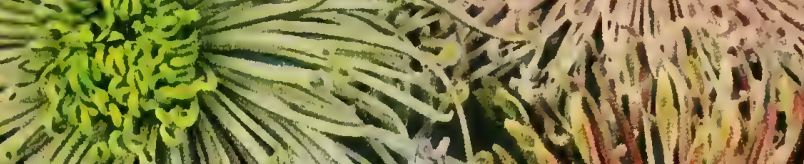
3 $\leq-1: 9)^{\prime}$

2

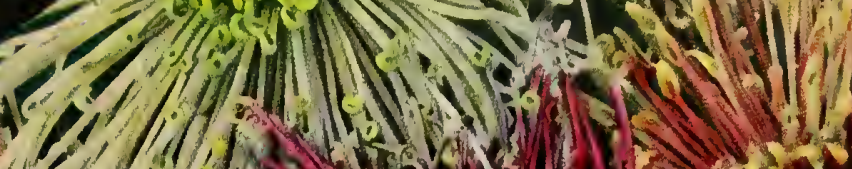
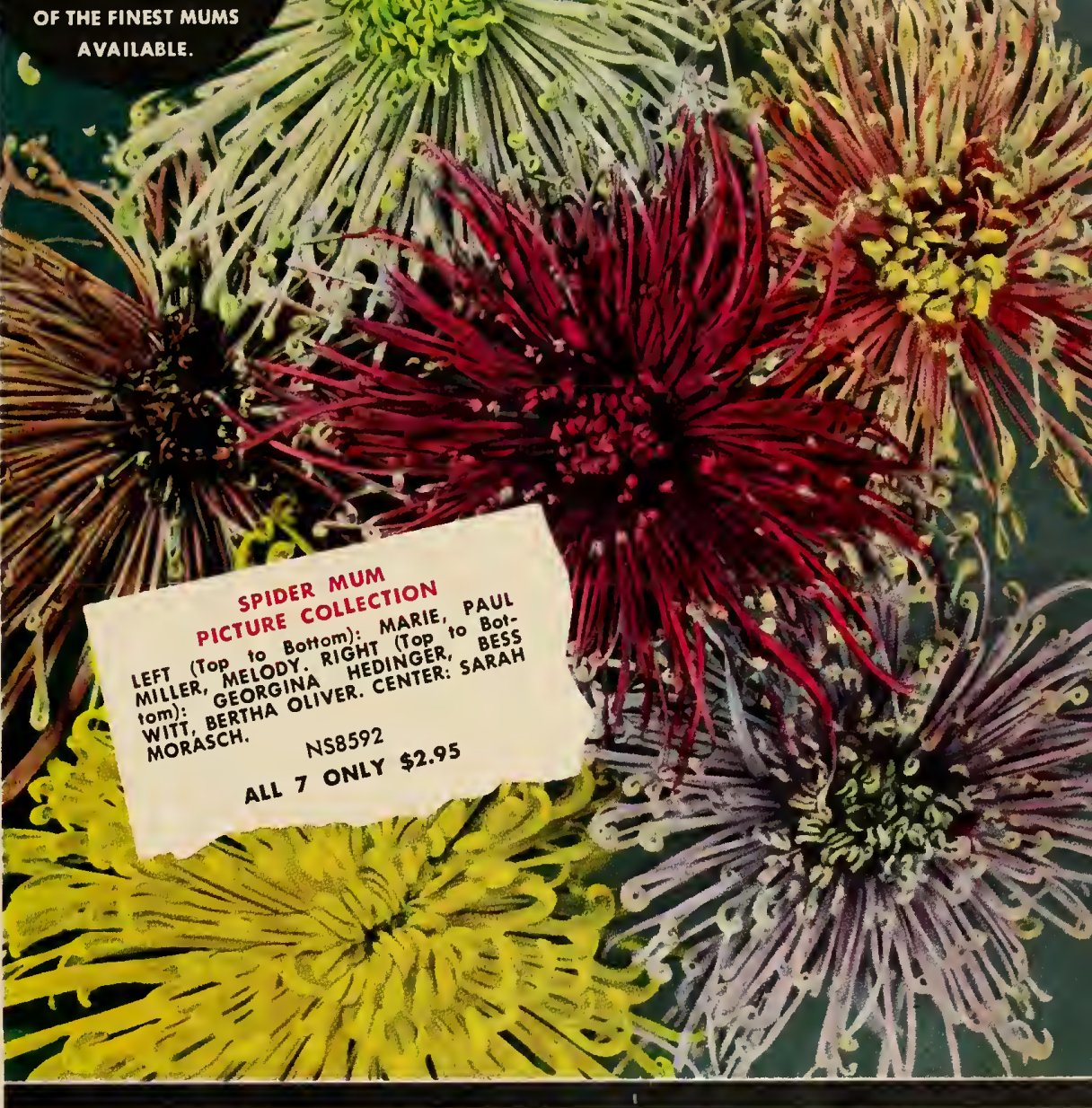

NS8540

EXHIBITION MUM COLLECTION

1 each Ambassador, Art Tashima, Bronze Champion, Butterball, Gwen Pattan, Grape Bawl, Orange Bowl, Caranatian Pink, Pack. ett's Maraan, Rase Bawl, Shirley Beauty, Watanabe, Say Edgar, PLUS the fabulaus STEPHANIE.

ALL 14 ONLY $\$ 5.50$
(\$7.50 value)

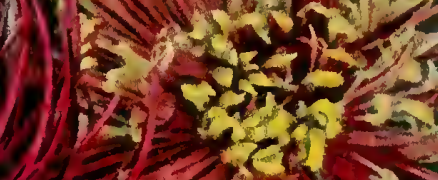

. 



\section{Now! germain's OFFER THE NEWEST AND FINEST IN GIANT HYBRID IRIS}

THESE OUTSTANDING VARIETIES are the results of years of breeding by the nation's most outstanding hybridizers. The iris of today are a far cry from the old varieties of our grandmother's garden. Today's NEW CREATIONS are as beautiful as the orchid.

The iris is truly the lazy man's or the busy man's answer to the problem of gardening in this age of speed. So much beauty for so little work.

SHIPPING: IMPORTANT-PLEASE NOTE. TO ASSURE YOU OF FRESH, DISEASE FREE RHIZOMES, THESE IRIS ARE HARVESTED IN LATE SPRING. YOUR ORDER WILL BE SHIPPED AT PROPER PLANTING TIME, APPROXIMATELY JULY $1 \mathrm{ST}$.

\section{HOW TO GROW IRIS}

There is no secret in growing iris-the following simple suggestions will insure success, and you will be more than repaid when the next iris-time comes around:

1. Select a sunny, well drained location.

2. Do not plant too deeply-the rhizomes should be just below the surface of the ground. Be sure the roots are firmed in the ground securely.

Keep well watered until the plants are established.

4. Fertilize lightly at least twice a year with a good commercial fertilizer, or well-decomposed manure, but be sure this does not come in direct contact with the rhizomes-it is the roots which need the food.

5. Divide and transplant iris every three years to insure maintaining good size flowers and abundant bloom.

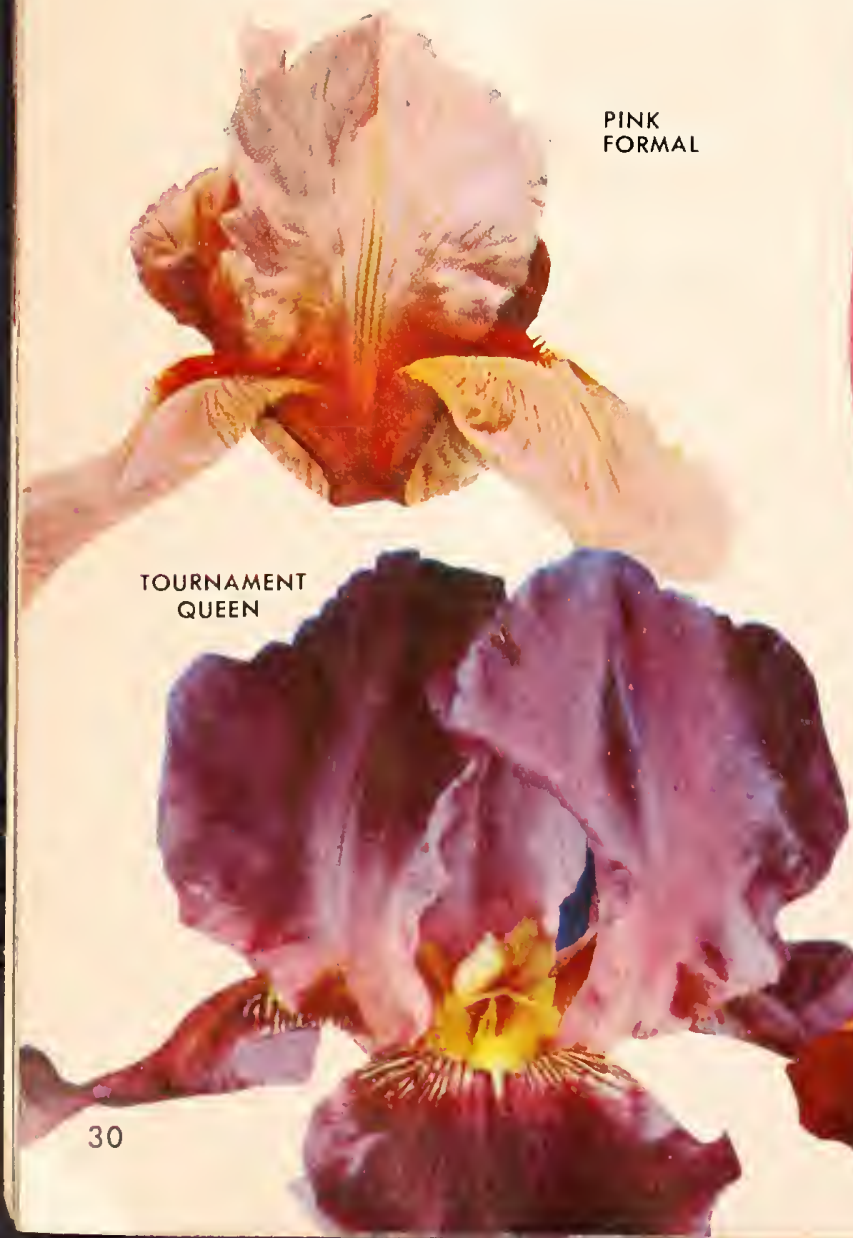

WHITES

\section{VARIETIES}

New Suow-Snow-white blossom with a rich yellow beard and heavy substance. NS8930 75c each

Tranquility - Serene white with a white beard, good form and substance. NS8931 \$1.00 each

White Ruffles-A white beauty, gracefully ruffed, broad and flaring petals. NS8932 \$1.00 each CREAMS

Desert Song-Large, ruffled cream or very light golden tan iris. NS8933 75c each

Lady Mohr-White standards; chartreuse fall with strong veining, patch of red-violet. NS8934 75c each

Star Shime-An iridescent cream with a pearly blue flush in the falls. NS8935 \$1.50 each

YELLOWS

Arcadia Buttercup-Brilliant deep yellow with a satiny sheen. NS8936 \$1.00 each

Gold Rnffles - A very beautiful soft yellow, frilled and ruffled. NS8937 75c each

Gold Sovereign-Medium sized flowers of a vivid and intense orange-yellow color. NS8938 75c each

Green Pastures-A chartreuse yellow with a touch of blue at the end of the beard. NS8939 \$1.00 each

Molir Beauty-Beautifully ruffled light yellow iris. Very large blooms. NS8940 \$1.50 each

Montecito-A very lovely iris in cool lemon-yellow and frosty-white. NS8941 \$2.50 each

Ola Kala-Deep yellow self. Stands up well in all weather. NS8942 75c each

Pinmacle-Clean white standards and primrose yellow falls NS8943 \$1.00 each

BRONZE AND BROWN SHADES

Argus Pheasant-A self of golden Argus-brown with a matching beard. NS8944 \$1.25 each

Russet Wings-A smooth blend of gold, copper and apricot melting into a true russet self. NS8945 \$1.00 each

Tobaceo Road - A self of a beautiful tobacco-brown color PINKS NS8946 \$1.00 each

Cathedral Bells-A light begonia of shrimp pink, with heavy substance and slight ruffling. NS8947 \$3.00 each

Cherie-A lovely flesh-pink iris sharply accented by a tangerine beard. NS8948 \$1.50 each

Clond Cap-Lovely, big pale apple-blossom pink with an extra heavy tangerine beard. NS8949 $\mathbf{\$ 2 . 0 0}$ each

Iappy IBirthday-Larger and more colorful than most other flamingo-pinks.

NS8950 \$2.50 each

Palomino-Standards pinkish buff; falls pale ivory overlaid ambercopper at the haft. NS8951 \$3.50 each

Pink Camea-A lovely translucent cameo-pink of good substance and excellent branching. NS8952 75c each

ARgús Pink Formal-Large ruffled deep pink flowers with a salmon inPHEASANT fluence.

NS8953 \$1.25 each

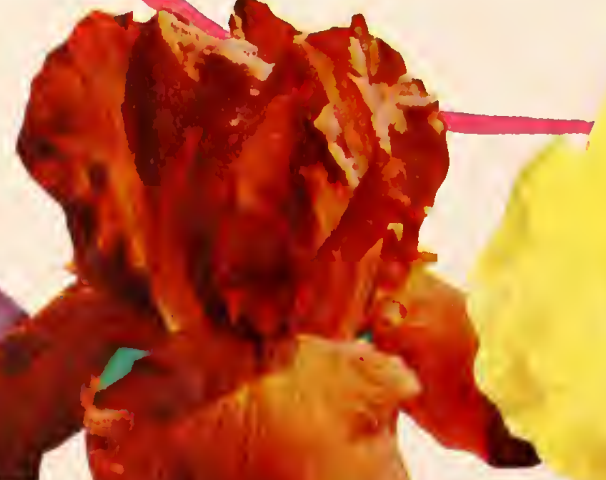

MOHR BEAUTY 
Maytime-Fresh two-toned lilac-pink with falls about three shades darker than the standards.

NS8954\$2.00 each

Driental Glory-Mahogany-red standards; deep chestnut brown falls. Brilliant blue blaze at tip of orange-yellow beard. NS8955 \$2.00 each

Savage-Flaring flowers of burnished red with a blue blaze. NS8956\$2.00 each

Solid Mahogany - A large mahogany-red self, fine form, smooth finish. NS8957 75c each

Technicolor-Brilliant red-brown; the color carries exceptionally well. NS8958 \$1.50 each

Tournament Queen-An enchanting shade of fuchsia with falls slightly darker than the standards. NS8959 \$1.00 each

Winstou Churelnill-A deep crimson red-the standards are a glowing red while the falls are velvety.

\section{BLUES}

NS8960 \$1.00 each

Blue Rhythm--Lovely cornflower blue iris. Blooms late.

Blumohr-A William Mohr seedling of lavender-blue.

$$
\text { NS8961 75c each }
$$

Cahokia-An exquisite shade of clear light sky-blue.

$$
\text { NS8962 \$2.00 each }
$$

NS8963\$1.00 each

Chivalry - Ruffled flowers of a medium blue, with just a hint of violet. NS8964\$1.00 each

Frances Craig-A classic in a Mohr type flower, with cool silvery lavender-blue blossoms. NS8965 \$3.00 each

Helen MeGregor-An ethereal light-blue iris of fine substance and refinement. NS8966 75c each

Mrs. Douglas Pattison-The color of this flower is the bluest of cornflower blue. NS8967 \$1.00 each

Pierre Menard-A medium toned hyacinth-blue iris.

\section{ORCHID AND VIOLET SHADES}

\section{NS8968 \$1.25 each}

Chantilly_-Pale orchid-pink, with the edges delightfully crinkled and ruffled. NS8969\$1.00 each

Elmohr-Rich mulberry with heavily ruffled standards and falls. NS8970 \$1.00 each

Raven Wing-Dark as a raven's wing, with much the same sheen. NS8971 \$2.00 each

Sahle-A glistening flower of very dark violet. Beautifully formed.

\section{NOVELTIES}

Burgundy Splash-Standards are a muted burgundy-red and the falls are creamyyellow heavily stippled a richer and more intense burgundy around the edges. NS8973 \$1.50 each

Engraved-Plicata of Onco breeding. Pearl grey flushed blue with an all-over pattern of steel grey veining. NS8974 \$2.00 each

Extravaganza-An amoena with white standards shading to cream; deep red-violet falls with a blue blaze. NS8975 75c each

Wabash-An amoena with pure white standards and rich velvety deep violet falls bordered white.

NS8976 60c each

Victorian Veil-Big ruffled, white ground covered in rose-violet lace. Standards somewhat lighter than the falls.

NS8977 \$2.50 each
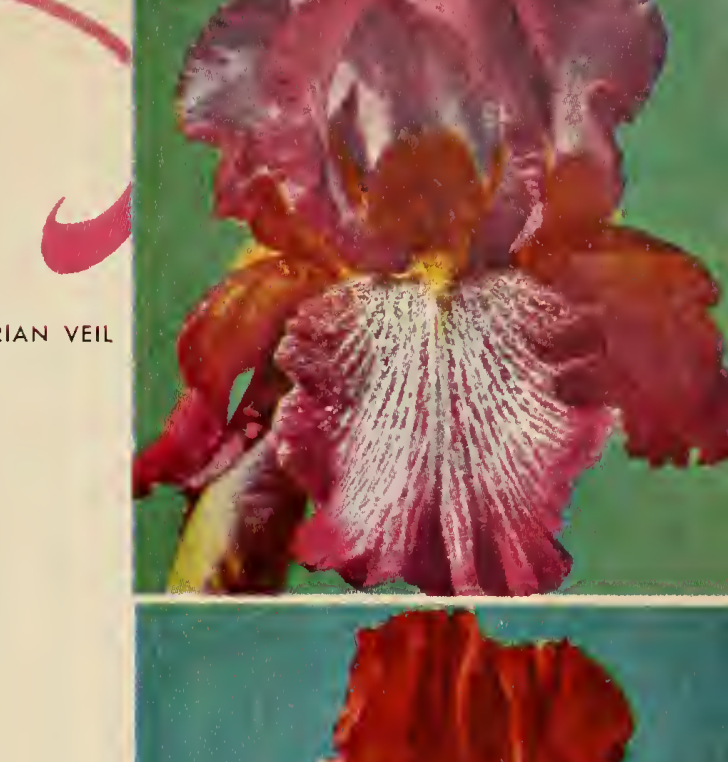

SAVAGE
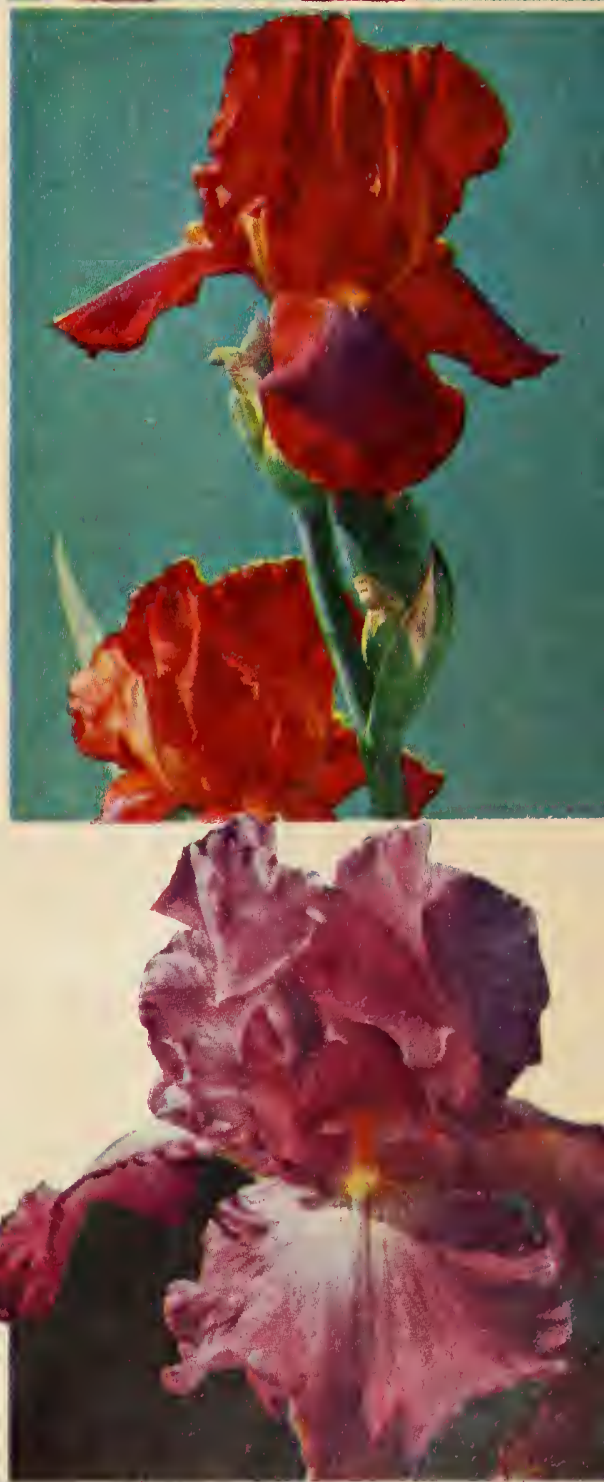

\section{PRINCESS \\ COLLECTION}

Cherie Ola Kala

Pierre Menard

Russet Wings

Technicolar

NS8983

All 5 only $\$ 4.25$

(\$6.00 Value)

\section{QUEEN'S}

\section{COLLECTION}

Blumohr Engraved Maytime Mantecita

Oriental Glory

Tranquility

NS8984

All 6 only $\$ 8.95$

(\$11.50 Value)

\section{KING'S}

COLLETION

Argus Pheasant, Bur-

gundy Splash, Cathe-

dral Bells, Frances

Craig, Maytime, Mahr

Beauty, Palomino,

Raven Wing, Savage, Starshine.

NS8985

All 10 only $\$ 18.00$

(\$21.25 Value
TIP.TOP COLLECTIOH

Claud Cap

Engraved

Mantecito

Savage

Taurnament Queen

NS8982

All 5 only $\$ 6.95$

(\$9.50 Value)
RAINBOW COLLECTION

Arcadia Buttercup

Blue Rhythm

Pink Cameo

Russef Wings

White Ruffles

N\$8980

All 5 only $\$ 3.25$

(\$5.00 Value)
SHOW COLLECTION

Frances Craig

Pink Formal

Pinnacle

Raven Wing

NS8981

All 4 only $\$ 5.50$

(\$7.25 Value) 


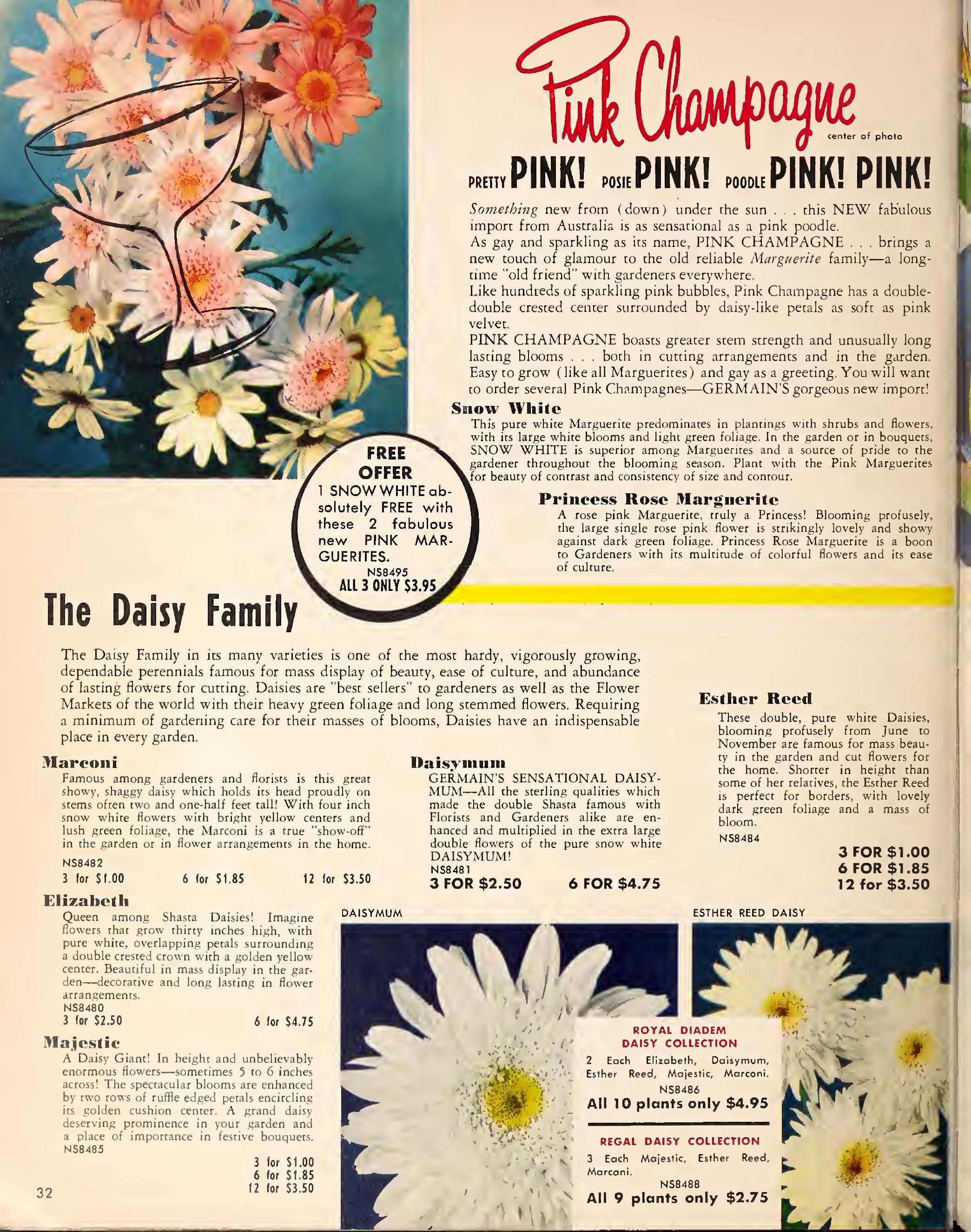




\section{EXOTIC TROPICAL PLANT}

Bird of Paradise OFFICIAL FLOWER OF LOS ANGELES

STRELITZIA REGINAE-The most exotic of all garden plants. The Bird of Paradise rivals the splendor of the tropical bird of paradise as it perches in the jungle trees. This flower with its combination of red, yellow, blue and orange is truly a thrilling garden spectacle.

EASY TO GROW out of doors wherever oranges thrive or very suitable as a tub plant in the colder sections. Should be left undisturbed in a sunny location in a rather rich soil and liberally watered for most abundant bloom.

The blooms last and last as cut flowers. In great demand by florists everywhere.

$\begin{array}{lll}\text { NS8671 } & 6 " \text { to } 9 " \text { Tall (1 } 1 / 2 \text { yrs.) } & \text { EACH } \$ 1.50 \\ \text { NS8672 } & 12 \text { " to } 14 \text { " Tall (3 yrs.) } & \text { EACH } \$ 2.50\end{array}$

\section{AMAZING SUN AZALEAS \\ GROW 3 TO 5 FEET TALL}

The fastest selling Azalea of all. Imagine! You can plant in full sun or partial shade. These fast growing, fine sturdy plants will flood your entire garden with beautiful massive blooms each spring. The finest for foundation plantings, rockeries, along shaded glens and paths. Terrific for hillside plantings. Practically no maintenance necessary except for general watering and normal care. Handsome green foliage year around. Will stand down to 28 degrees without freezing. For areas where temperature drops below 28 degrees, winter protection must be given. Large 2 year old plants out of gallon cans, will bloom first season.

White April-NS8610-(Illustrated). Giant pure white flowers set off mag-
nificently by lustrous green foliage. Fast grower.

Phoenicia-NS8611-The most outstanding Sun Azalea of all! Masses of large deep lavender flowers over a long blooming
period. VERY STURDY GROWERS.

Pride of Dorking-NS8612-(Illustrated). Brilliant new sparkling red. Late blooming make
plant perfect for Mother's Day.

\section{Southern Charm_NS8613-(Illustrated). Charming as the Old South. Delightful watermelon pink flowers}

Glory of Sunning Hill-NS8614-

Sensational, eye catching, large orange scarlet blooms. Dark green lush foliage and fairly low growing. Excellent for a border of Sun Azaleas.

George Taber-NS8616-Giant flowered Iilac tinted blooms with deeper colored dots on uptinted blooms with deeper
per petals. A real novelty.

\section{ANY OF THE ABOVE SUN AZALEAS $\$ 1.95$ EACH \\ 3 FOR $\$ 4.95$}

SUN AZALEA COLLECTION

I EACH OF THE ABOVE SUN AZALEAS NS8615 ALL 6 FOR \$9.50

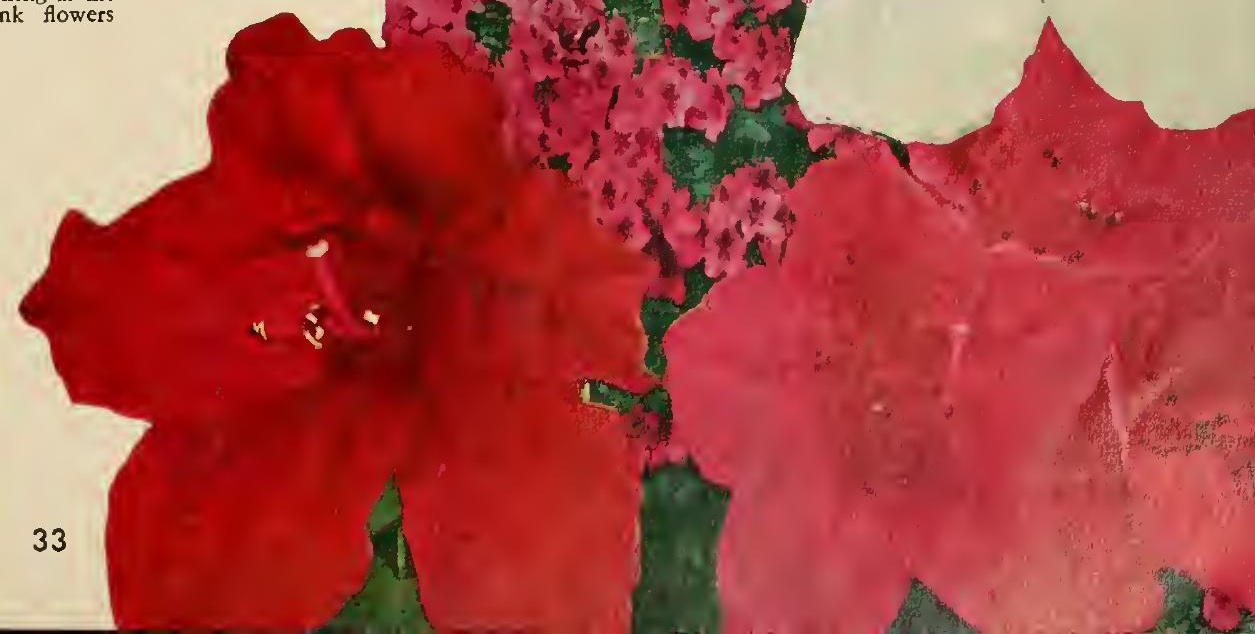


An Amazing

Ever-Bearing Strawberry Variety

THINK OF IT! 50 PINTS OF LUSCIOUS BER-

RIES FROM JUST 25 PLANTS-THE VERY

FIRST YEAR!

\section{GERMAIN'S Fabulous \\ (20th Century Selected) \\ HUGE, DELICIOUSLY SWEET, RICH RED STRAWBERRIES OFTEN AS EARLY AS 60 DAYS AFTER PLANTING}

\section{Stramber}

o 14

Germain's outstanding Strawberry "SWEETHEART" (20th Century Selected) is so prolific it produces a full, abundant crop the very first year. Planted in Spring it will bloom and set berries in 6 to 8 weeks. The berries are of such exceptional size you'll say you never saw strawberries so big before. The color is brilliant, sparkling red and the luscious, firm flesh is.deliciously sweet. In California and the West it bears three main crops each year and out-produces other varieties by a wide margin, even in the first year.

N58901

25 for $\$ 2.95$

50 for $\$ 5.50$

100 for $\$ 9.95$

University of California

\section{Tested Strawberries}

University varieties of Strawberries that have been thoroughly tested by the University of California.

25 for $\$ 1.95$

100 for $\$ 6.95$
Lassen N58903

Shasta NS8904
The largest berry of the University type. Fruit bright red, extra large, with fine flavor. Recommended for coastal conditions.

\section{NEWEST DEVELOPMENT IN DECADES}

IMAGINE! Both a beautiful lush dark green ground cover PLUS delicious fresh strawberries.

\section{Hybrid Ornamental Strawberry \#25}

Originated in California by Dr. L. W. Lenz. It has done extremely.well in nearly every area in the United States. If you can grow strawberries, you can grow ORNAMENTAL HYBRID \#25 with ease. Space plants about 18 to 24 inches apart in any good garden soil and watch 'em grow. Will grow to a height of 18 to 24 inches, very dense. If ground freezes in your area, cover with 1 to 2 feet of straw after first freeze; remove straw after the thaw in spring.

N58900

25 for $\$ 2.95$

$\mathbf{5 0}$ for $\mathbf{\$ 5 . 5 0}$

100 for $\$ 9.95$

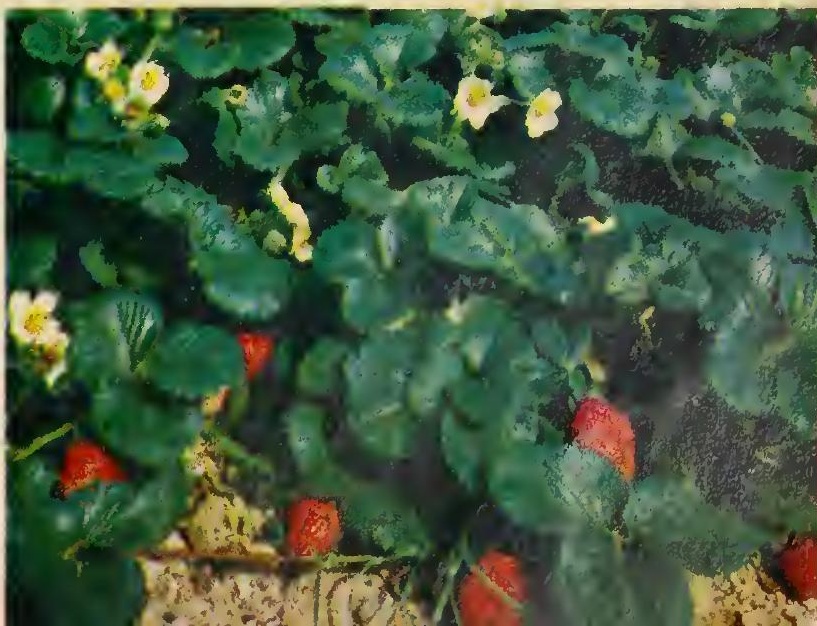




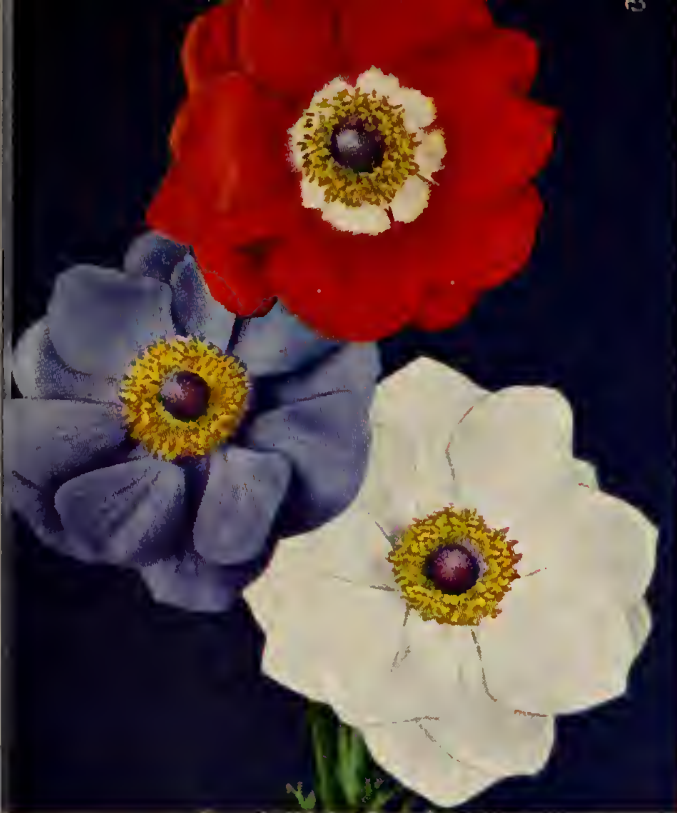

ANEMONES

Giant French Anemones

Now! Germain's selected BEST! Another New fast growing favorite flower that can be planted along with the brilliant RANUNCULUS-any time from August to Spring. (Plant in early Spring in cold areas.)

These Giant French Anemones resemble enormous poppies, and come in exciting bright hues of blue, red, pink and white.

No. 5025-MIXED COLORS LARGE BULBS

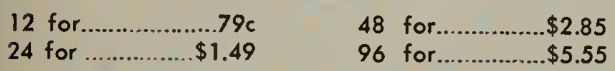

Anemones

These bargain bedding size bulbs will produce an abundance of 3 to 4 -inch flowers in exciting colors the very first year.

No. 5030 50 BULBS ONLY $\$ 1.00$

\section{SPECIAL OFFER \\ HUGE GOLDEN CALLA LILY BULBS}

Yesl Mommoth bulbs, lorger thon any offer we hove made in the post. FOR SPECIAL POT PLANTS AND SPECIMENS.

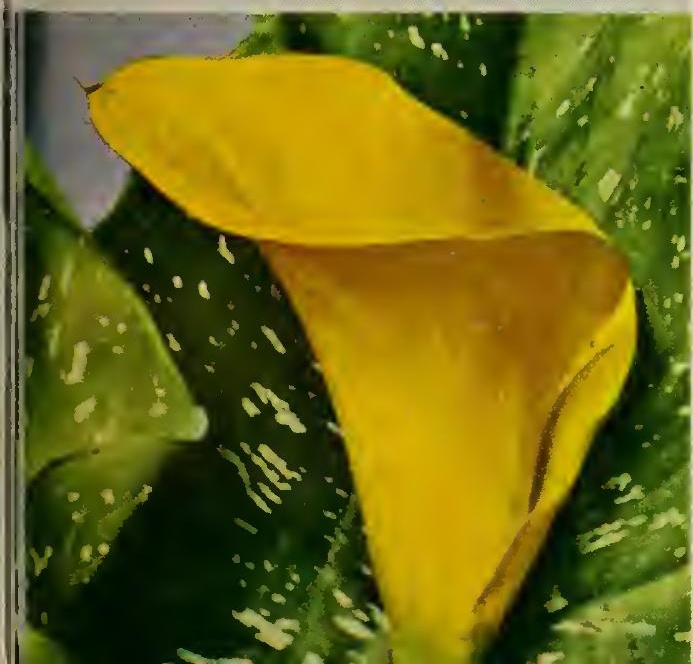

Giant Blooming Ranunculus

America's Favorite Cut Flower

Largest Strain in the World!Camellia Flowered

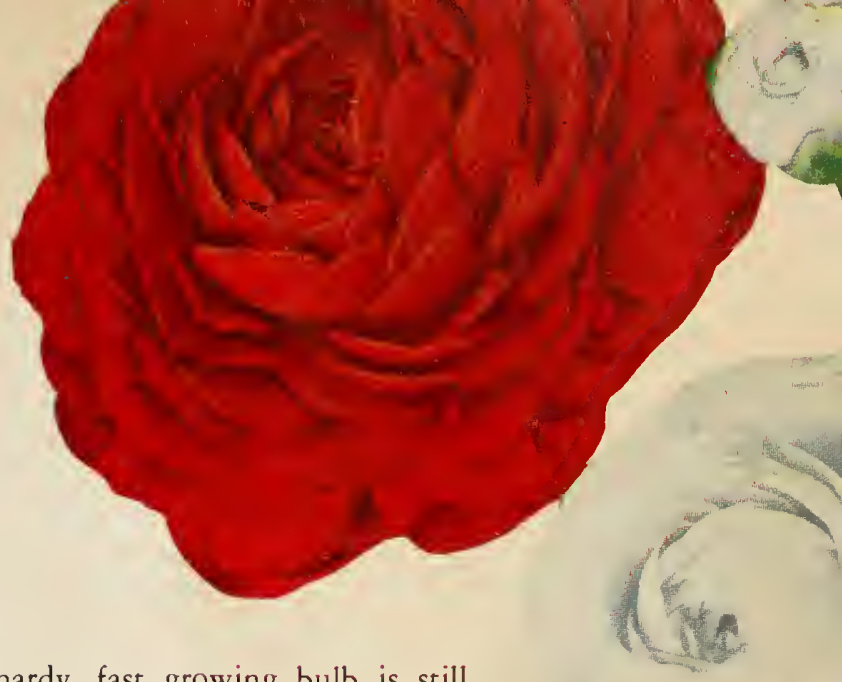

The popularity of this semi-hardy, fast growing bulb is still growing by leaps and bounds throughout the nation. This season, flowers are better than ever. The Ranunculus is EASY TO GROW and will produce an abundance of glorious Camellia flowered blooms for weeks and weeks. You can plant them in your garden any time from August to Spring in areas of mild winters. (If you have severe winters, plant after freezing.) The exceptionally bright, beautiful and exotic colors will fill your garden with unsurpassed beauty and brilliance.

\begin{tabular}{|c|c|c|c|c|c|c|c|c|c|}
\hline & & & \multicolumn{7}{|c|}{ No. 5040-MIXED COLORS } \\
\hline & JUMBC & BULBS & & & & & EXTRA & LARG & \\
\hline 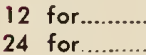 & $\begin{array}{r}\ldots . \$ 1.55 \\
\ldots . \$ 2.95\end{array}$ & $\begin{array}{l}48 \text { for. } \\
96 \text { for. }\end{array}$ & $\begin{array}{r}\$ 5.75 \\
\$ 11.25\end{array}$ & $\begin{array}{l}12 \\
24\end{array}$ & $\begin{array}{l}\text { for... } \\
\text { for... }\end{array}$ & .............. & $\begin{array}{l}\$ 0.98 \\
\$ 1.85\end{array}$ & $\begin{array}{l}48 \mathrm{fc} \\
96 \mathrm{fc}\end{array}$ & For $\begin{array}{l}\text { for......... } \$ 3.60 \\
\text { for } \$ 7.10\end{array}$ \\
\hline
\end{tabular}

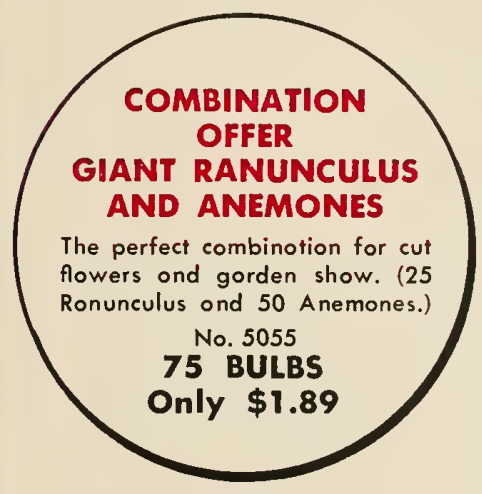

\section{Calla Lilies}

Golden Yellow

Grand, deep yellow flowers on tall stems. Leaves are spotted white.

No. 5148

3 BULBS ONLY $\$ 1.00$

\section{Calla Lilies}

Rare Pink

Exceptionally lovely calla produces dainty carmine rose flowers about $2^{\prime \prime}$ in diameter.
SPECIAL MONEY.SAVING COLLECTIOH OFFER-RANUNCULUS

Best Bulb borgoin ever offered. These bedding size Ronunculus bulbs will prill highlight your colorful cut flowe

$$
25 \text { BULBS OINLY } \$ 1.00
$$

SENSATIONAL BARGAIN OFFER FOR MASS GARDEN DISPLAY 作

$$
\text { No. } 5051
$$

Mixed Colors-Blooming Size Bulbs

$1 / 4$ lb. (Approximotely $\$ 6.75$ 作

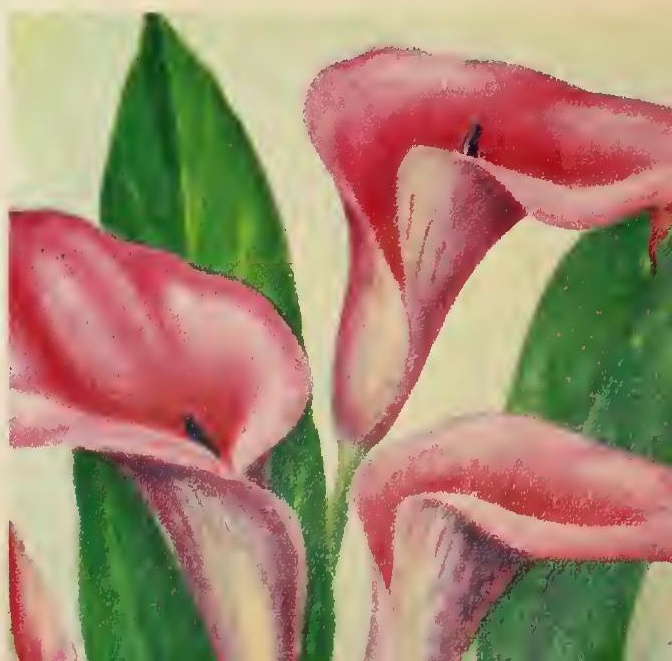




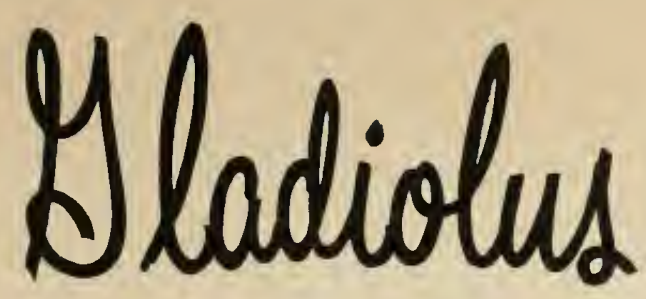

GERMAIN'S AGAIN OFFERS GLADIOLUS BULBS TREATED BY HEAT THERAPY

High crowned \#1 bulbs from COOKED PLANTING STOCK! By this we mean these bulbs were produced from smaller bulbs or bulblets that were HOT WATER TREATED. Yes, actually immersed in hot water to destroy disease common to gladiolus such as fusarium, crown rot, bacterial scab, and the minor diseases. This process, now perfected, has proven a boon to the gladiolus industry. A clean buib produces a much better flower and is a healthier propagator than the untreated gladiolus.

SPECIAL NOTE: Only Offer No. 5273 is processed from cooked plonting stock.

Crater Lake (Midseoson) Lorge violet-blue with slight creom feother in throot.

Carnival (Eorly midseoson) Bright scorlet with cleor white throat. Ruffled.

King David (Midseoson) Deep velvet purple with o silver picotee edging on the petals. Ruffled.

White Gymbhony (Eorly midseason) Heovy textured snow white. Ruffled and fluted.

Lady Jane (Midseason) Cleor creom with yellow lip petols. Ploin petoled.

Picardy (Midseason) Large solmon pink with a slight feother in the throot. Ploin petoled.

Poinsettia (Midseason) A pure light red with no morkings in the throot. Ruffed.

Alfred Nobel (Lote) "Azaleo" pink with on explosion blotch of creom extending olong ribs.

Lavender Reauty (Midseason) Orchid lavender with foint creom lines on o slightly deeper lovender throot. Frilled. Lila Wallace (Eorly midseoson) A smoll deep velvet rose.
Ruffled.

Paradise (Early) Large opricot with a norrow line of scorlet in the throat. Plain petoled.

Belle Jaume (Very early) Medium deep yellow. Ploin petoled. No. 5273

12 BULBS (I EACH ABOVE VARIETIES)

24 BULBS (2 EACH ABOVE VARIETIES)

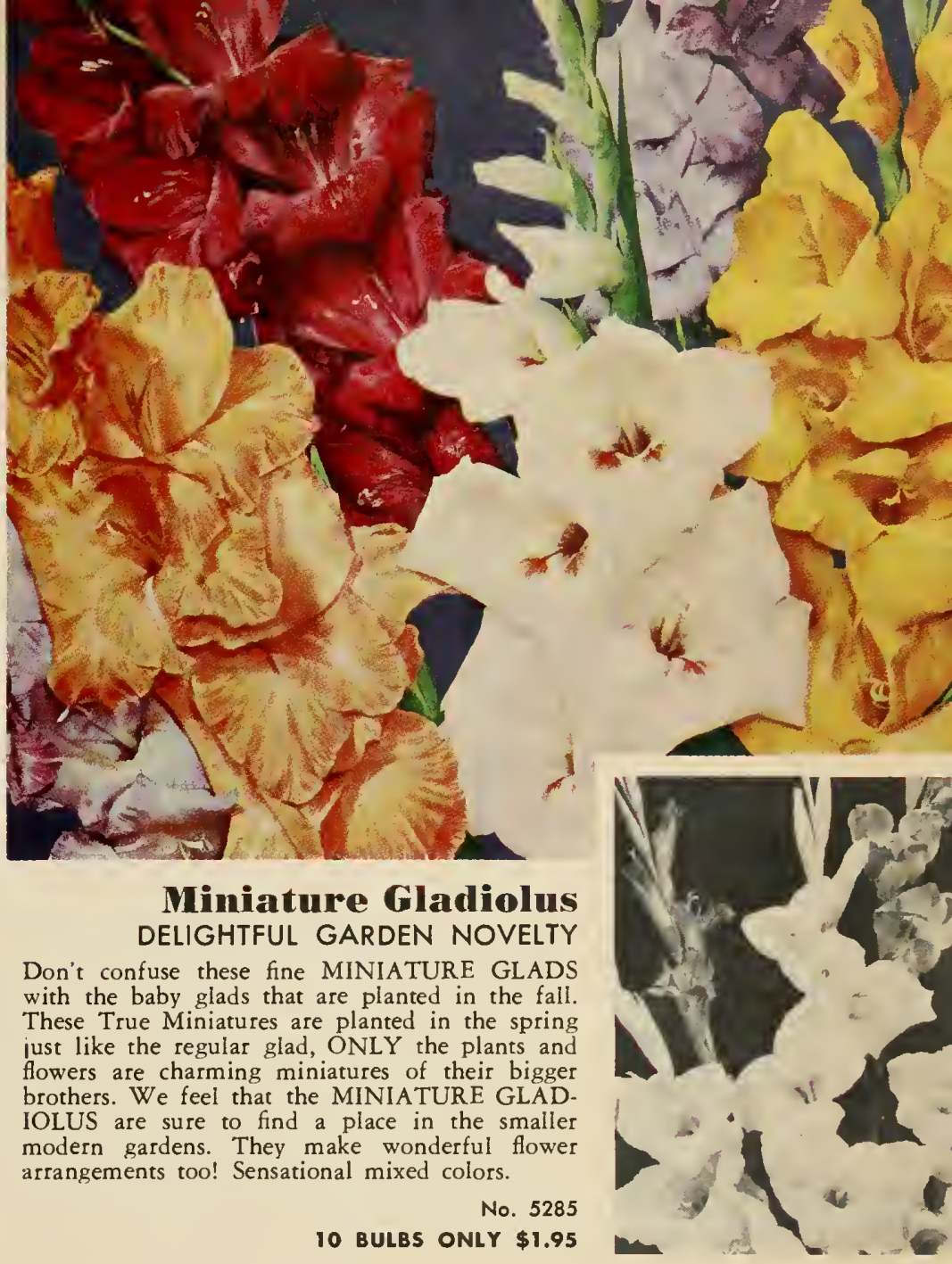

10 BULBS ONLY $\$ 1.95$
ONLY $\$ 1.45$

ONLY $\$ 2.65$

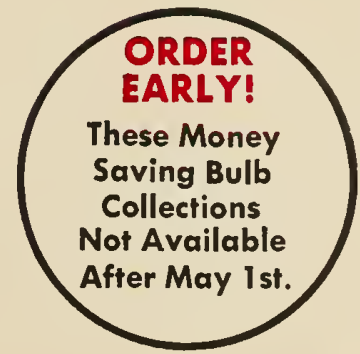

\section{Giant Amaryllis}

AMERICAN HYBRIDS

A really out of the ordinary strain of Amaryllis. Giant trumpet flowersstriped and blotched, with glossy straplike leaves. You can grow them outdoors in mild climates, or in colder climates use them as pot plants or in window boxes. Very easy to grow. Mixed colors.

No. 5005

3 for $\$ 1.39$

6 for $\$ 2.69$

\section{GERMAIN'S FAMOUS \\ TIP TOP GLADIOLUS COLLECTION THE ALL-TIME FAVORITE \\ You'll pick ormloads of flowers for weeks ond weeks from these especially selected vorieties produced from LARGE \#1 size bulbs. A well bolonced mixture.

$$
\text { No. } 5279
$$

$\begin{array}{rrrr}25 & \text { BULBS } & \ldots . \text { ONLY } & \$ 2.25 \\ 50 & \text { BULBS } & \ldots . . \text { ONLY } & \$ 4.25 \\ 100 & \text { BULBS } & \ldots . . \text { ONLY } & \$ 7.95\end{array}$

\section{GERMAIN'S SPECIAL GLADIOLUS \\ BARGAIN COLLECTIONS}

Medium size bulbs, but lorger thon the bulbs used by commerciol cut flower growers in Southern Colifornio. Beoutiful flowers from every bulb. This is our FAMOUS " $\$$ " SPECIAL in Glodiolus.

$$
\text { No. } 5278
$$

$\begin{array}{llll}15 & \text { BULBS } & \ldots . . . & \text { ONLY } \$ 1.00 \\ 30 & \text { BULBS } & \ldots . . . & \text { ONLY } \$ 1.89 \\ 45 & \text { BULBS } & \text {...... ONLY } & \$ 2.75 \\ 60 & \text { BULBS } & \ldots . . . & \text { ONLY } \$ 3.65\end{array}$





\section{H. G. GERMAN, SEEDS \\ PHONE 436 - - SMETHPORT, PA.}

PLEASE PRINT NAME AND ADDRESS

NAME

PLEASE USE SAME FIRM OR GREENHOUSE NAME ON ALL OROERS TO AVOIO CONFUSION ON OUR RECOROS
Cash should accompany all orders unless credit has been established. Make all checks or money orders payable to

\section{H. G. GERMAN, SEEDS} SMETHPORT, PA.

We cannot be responsible for currency sent in the mail.

Limitation of Warranty, $H$. G. German, Seeds, warrants to the extent of the purchase price that seeds, plants, or materials sold are is described on the container within recognized tolerances. Seller gives no other or further warranty, express or implied.

CASH D/SCOL NT ON SEED ORDERS ONLY when cash is enclased: under $\$ 5.00$, net; $\$ 5.00$ to $\$ 25.00,5 \%$; $\$ 25.00$ to $\$ 100.00,8 \% ; \$ 100.00$ to $\$ 150.00,10 \% ; \$ 150.00$ to $\$ 200.00,12 \%$

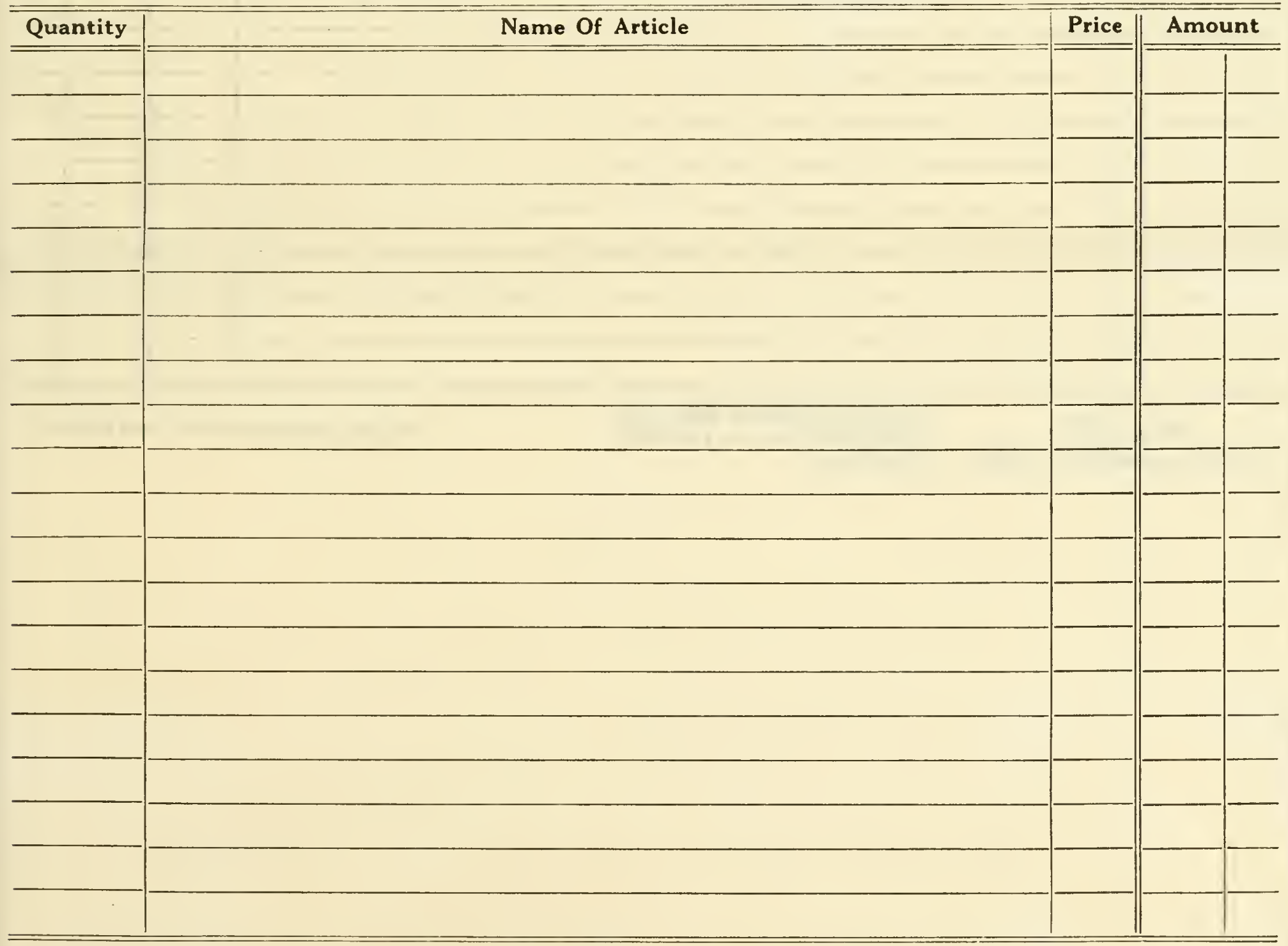

In ordering supplies, be sure to state how shipment should be made, Freight, Express or Truck, otherwise we'll use our best judgment.
See over for additional space.

If you need more order blanks check here ( ). 


\begin{tabular}{|c|c|c|c|}
\hline Quantity & Name Of Article & Price & Amount \\
\hline & & & \\
\hline & & & \\
\hline & & & \\
\hline & & & \\
\hline & & & 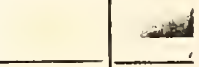 \\
\hline & & & \\
\hline & & & \\
\hline & & & \\
\hline & & & \\
\hline & & & \\
\hline & & & \\
\hline & & & \\
\hline & & & \\
\hline & & & \\
\hline & & & \\
\hline & & & \\
\hline & & & \\
\hline & & & \\
\hline & & & \\
\hline & & & \\
\hline
\end{tabular}

PLEASE:

We invite constructive criticism.
If you have received seeds from us that do not suit you just pencil it down here:
See note on other side about Cash Discount. 
